Faculdade de Filosofia, Letras e Ciências Humanas Departamento de Teoria Literária e Literatura Comparada

GABRIEL SALVI PHILIPSON

\title{
ENTREMEIOS DA LITERATURA E DA FILOSOFIA - O HUMANO ENTRE FANTASIA E REALIDADE EM $O$ MESTRE E MARGARIDA DE M. BULGÁKOV
}

versão corrigida

SÃO PAULO - S.P. 
GABRIEL SALVI PHILIPSON

\section{ENTREMEIOS DA LITERATURA E DA FILOSOFIA - O HUMANO ENTRE FANTASIA E REALIDADE EM O MESTRE E MARGARIDA DE M. BULGÁKOV}

Dissertação de mestrado apresentada ao Programa de Teoria Literária e Literatura Comparada da Universidade de São Paulo, para obtenção do título de Mestre em Letras

Orientador: Prof. Dr. Marcus Vinicius Mazzari

Versão corrigida

SÃO PAULO - S.P.

2017 
Autorizo a reprodução e divulgação total ou parcial deste trabalho, por qualquer meio convencional ou eletrônico, para fins de estudo e pesquisa, desde que citada a fonte

P558

PHILIPSON, GABRIEL SALVI

ENTREMEIOS DA LITERATURA E DA FILOSOFIA - O HUMANO ENTRE FANTASIA E REALIDADE EM O MESTRE E MARGARIDA DE M. BULGÁKOV / GABRIEL SALVI PHILIPSON ; orientador MARCUS VINICIUS MAZZAri. - São Paulo, 2017.

$145 \mathrm{f}$.

Dissertação (Mestrado) - Faculdade de Filosofia, Letras e Ciências Humanas da Universidade de São Paulo. Departamento de Teoria Literária e Literatura Comparada. Área de concentração: Teoria Literária e Literatura Comparada.

1. TEORIA LITERÁRIA. 2. crítica literária. I. MAZZAri, MARCUS VINICIUS, orient. II. Título. 
PHILIPSON, Gabriel Salvi

Entremeios da literatura e da filosofia - O humano entre fantasia e realidade em $O$ Mestre e Margarida de M. Bulgákov

Disseração apresentada ao Programa de Teoria Literária e Literatura Comparada da Faculdade de Filosofia, Letras e Ciências Humanas, da Universidade de São Paulo, para obtenção do título de Mestre em Letras.

Aprovado em:

Banca Examinadora

Prof. Dr.

Instituição:

Julgamento:

Assinatura:

Prof. Dr.

Instituição:

Julgamento:

Assinatura:

Prof. Dr.

Instituição:

Julgamento:

Assinatura: 
Para Valdívia, Silvia e Jurn, em lembrança, por inspirarem esta trajetória Para Pedro (in memoriam), pelo gosto de fantasia Para Antonietta, pelo sarcasmo que me desviou 


\section{Agradecimentos}

Agradeço, de início, ao meu orientador, Marcus Vinicius Mazzari, pela confiança, apoio e rigor no acompanhamento deste estudo.

Agradeço ao Homero Freitas de Andrade, pelo entusiasmo, amizade e franqueza com que participou desde o início deste longo processo, e pelos seus comentários e sugestões sempre muito produtivos em nossas inúmeras conversas ou no rito oficial das bancas.

Agradeço à Professora Aurora Fornoni Bernardini, por sua leitura profunda e cuidadosa na ocasião do Exame de Qualificação, e por todas as sugestões que fez naquela ocasião.

Em tempos de possíveis mudanças nas políticas de financiamento da pós-graduação, não posso deixar de agradecer à CAPES, pelo auxílio financeiro, sem o qual não seria possível me dedicar com o afinco necessário à pesquisa.

Gostaria de agradecer a Maria Ângela, Suely, Maria e Luiz, pelo apoio institucional e modo atencioso com que colaboraram ao longo destes anos, desde as provas do processo seletivo até a defesa.

Agradeço à minha família e, em especial, aos meus pais, Emanuela e Ivo, pelo apoio, incentivo, compreensão e, principalmente, paciência. Ainda no âmbito familiar, por terem me acompanhado e apoiado durante o processo, ao irmão Marcos, e às tias Anna Elena Salvi e Luiza Luciana Salvi.

Agradeço a leitura atenta deste estudo e os comentários de Ana Novi e de Eduardo Soma no âmbito de nosso grupo de estudos, e também de Marcos Vinicius Ferrari.

Agradeço, pelas longas conversas e inestimáveis contribuições ao longo deste processo, aos amigos Jorge Manzi e Fabio Roberto Lucas.

Aos colegas da Revista Magma, Rafael Ireno, Daniel Glaydson Ribeiro e Talita Mochiute.

Ao Vinicius Marques Pastorelli. Ao Alexandre Lúcio Sobrinho, pela ajuda em tempos difíceis.

Ao Marco Aurélio Werle e ao Luiz Fernando Martin. Ao Marcos Natali. Ao Marcus Sacrini Ayres Ferraz.

Pelos ensinamentos de língua russa e conversas, a Natalia Quintero e Maria Petrova. 
Aos amigos de longa data, companheiros por trilhas, com bola na mão ou de papo, Igor Camargo, Felipe Freller, Irene Monteiro, Tássia Almeida, Domitila Sakamoto, Moacyr Ambrosino, João Marcos Sakamoto, Arnaldo Sakamoto, Sandro Bürgi, Adriano Burgi, Sérgio Burgi, Caterina Salvi, Maki Shintate, Ricardo Zimmermann, Bruno Bernardo, Mônica Marques, Fernando del Lama, Jeferson Oliveira, Bibiana Sardella, Dayana Prado, Dafne Setton, Filipe Favaro, Heitor Gimenez, Tamara Fajer, Marcela Monaco, Lais Kasahaya, Dandara, Anna Turriani, Lenin Bicudo, João Cortese, Marcos de Lucca-Silveira, Paulo Pirozelli, Lucas Petroni, Diego Sime, André Paes Leme, André Botelho, Mari Alter, Fernando Sepe, Júlia Chiacchio, Antonio Ramires, Lucas Schnaiderman, Ariane Faria, Nara Lasevicius, Luana Xavier, Carlos Gontijo, Renata Esteves, Phillipe Martins, Moara Cappellari, Cassia Marconi, Yuri de Oliveira, Pedro Augusto Pinto, Yasmin Afshar, Hannah Maruci, Michelly Silva, Henrique Radesca, Bruno Monachini, Martin Nery, Renata Praxedes, Thiago Nascimento, Leonardo Carmo, André Moreira, Guilherme Zamboni, Thiago Badaró, Gustavo Vellutini, Paulo Beer, Francisco Haddad (in memoriam), Cauê Ranzeiro, Diego Moraes, Orlando Martes, Marcelo Noffs, Rubens Mandel, João Coscelli, Renato Tescari, Duanne Ribeiro, Cris Camargo, Clara Serva, Muriel Araújo, Pedro Bacchi, Marieta Ribeiro, Thomas de Barros, Vitor Barros, Marcel Enderle, Ina Nunes, André Castro, Eduardo Horie, Rafael Cardoso, Renato Gomes, David Camello, Estrella Maestre e Lucas Machado.

Agradeço à Cau Silva, pelos abraços que me fizeram chorar. 
Resumo

Nesta dissertação me proponho a analisar o romance $O$ Mestre e Margarida (1940) de M. Bulgákov a partir das noções de humano, fantasia e realidade. Para isso, inicio por uma análise do primeiro capítulo do romance de Bulgákov em aproximação com o romance realista socialista, buscando elementos com que Bulgákov se contrapõe ao realismo socialista. Sugiro, aqui, que esses elementos teriam ligação com questões éticas e de modos de representação do real, de tal modo que essas questões residem no cerne temático e formal do romance. Em seguida, me proponho a analisar o entremeio entre o primeiro capítulo de $O$ Mestre $e$ Margarida, que se passa em Moscou, e o segundo capítulo, o romance dentro do romance, a história de Pôncios Pilatos e Jeshua escrita pelo personagem Mestre. Nesse momento, estou preocupado em discutir três temas principais: a. a função do fáustico no romance, bem como outras questões a ele associadas, como o problema do valor em Goethe, Binswanger, Nietzsche e Heidegger leitor de Nietzsche; b. o modo como um romance está dentro do outro, uma vez que, entre outras coisas, o modo como se dá a passagem entre um e outro é variado e instaura uma questão sobre a qual não poucos críticos se debruçaram; e c. a singularidade do procedimento paródico presente no romance, a qual me leva a enveredar por um estudo da sátira menipeia de Bakhtin, em consonância com alguns pontos de seus textos iniciais, preocupados, por exemplo, com o problema da responsabilidade. Por fim, passo a uma análise do segundo capítulo de $O$ Mestre e Margarida, o assim chamado romance dentro do romance, que narra à sua maneira - a interação entre Jeshua e Pôncios Pilatos. Aqui, aproximo dessa narrativa algumas questões relacionadas ao nietzschianismo russo e a Nietzsche, tendo em vista hipóteses trabalhadas nos momentos anteriores deste estudo. Nesse percurso, as desenvolvo e aprofundo, principalmente a respeito de assuntos como a recepção de aspectos da filosofia alemã no contexto russo-soviético e o lugar complexo de $O$ Mestre e Margarida no modernismo.

Palavras-chave: Mikhail Bulgákov, O Mestre e Margarida, nietzschianismo russo, elemento fáustico, realismo socialista. 


\begin{abstract}
In this dissertation I propose an analysis of M. Bulgakov's novel The Master and Margarita (1940), considering the notions of human, fantasy and reality. For this purpose, I begin by an analysis of the first chapter of Bulgakov's novel, approaching it to socialist realist novel, aiming to find elements in which Bulgakov counteracts socialist realism. I suggest these elements have to do with ethical matters and with issues about how to represent the real, in a way that these matters and issues rest on the novel's thematic and formal heart. Afterwards, I propose to analyse the intermedium (entremeio) between The Master and Margarita's first chapter, which takes place in Moscow, and the second chapter, which is the novel inside the novel, the story of Pontius Pilate and Yeshua written by the Master, the character. At this point, I am concerned with three main themes: a. the function of the faustic in the novel and related matters, like the value issue in Goethe, Binswanger, Nietzsche and Heidegger as Nietzsche's reader; b. the way in which a novel is inside the other, since the link between one and another varies, posing an issue handled by several critics; and c. the singularity of the parodic procedure found in the novel, which leads me to embark on a study of Bakhtin's menippean satire in consonance with some points of his first texts that are concerned, for example, with the issue of the answerability. Finally, I analyse the The Master and Margarita's second chapter, the so called novel inside the novel, which tells - in its own ways - the interaction between Yeshua and Pilate. I articulate it here with some issues connected with the Russian Nietzscheanism and with Nietzsche himself considering assumptions that I've worked previously. In this route, I advance assumptions about issues like the reception of aspects of German philosophy in Russian-soviet background and The Master and Margarita's intricate place inside modernism.
\end{abstract}

Keywords: Mikhail Bulgakov, The Master and Margarita, Russian Nietzscheanism, faustic element, socialist realism. 


\section{Sumário}

Metafísicas literariamente teóricas e comparativamente literárias

Entremeios da filosofia e da literatura

"Isto não pode ser verdade" - a ficção (humana): a fantasia como sátira nos tempos dos realismos socialistas 25

Entremeios (do incidental): a paródia, o elemento fáustico e o problema da união dos romances - os espaços vazios como horizonte ético do literário

Jesus-rebus-Pilatos: a questão do real pela polifonia de métodos de representação.......107

Considerações finais

Referências Biliográficas 


\section{Metafísicas literariamente teóricas e comparativamente literárias}

Filosofamos em geral no Brasil? Essa é a primeira pergunta. Primeiramente quero excluir da discussão duas respostas possíveis. A primeira é a seguinte: naturalmente nós filosofamos, pois o filosofar é, como já dito, humano em geral. Cada homem duvida de suas condições e toma uma posição irônica, ou seja, distanciada delas. A outra corresponde ao seguinte: nós no Brasil filosofamos, e as faculdades de filosofia em nossas universidades e os seus textos ou de seus vizinhos, que há pouco começaram a surgir, comprovam isso.

Eu quero excluir essas respostas, mas por motivos opostos. É verdade que essas faculdades e textos são disciplinados, mas são eles também inspirados nesse espírito de rebelião que fariam deles antes de tudo filósofos? Minha pergunta pela existência em geral de uma filosofia no Brasil deve então ser a seguinte: há no Brasil um duvidar e distanciar verdadeiros, mas disciplinados? Assim formulada, essa pergunta não tem uma resposta muito fácil. Ela não é talvez em geral objetivamente existente.

Há em enorme quantidade duvidar e distanciar indisciplinado entre nós. (...) $\mathrm{O}$ intelectual, o literato e principalmente o advogado incorporam essa posição. Eles acoplam-se como literatura, como crítica literária ou como aperçus frouxo. Pode-se as indicar como ecleticamente selvagens. Trapos de temas só superficialmente lidos ou mesmo apenas superficialmente ouvidos são rapidamente remendados e se forma um todo aventuresco. (FLUSSER, 1994, p. 230).

O texto que vem a seguir não irá se mostrar como um todo acabado, uma espécie de ponto de chegada após três anos de pesquisa e estudo. Ao contrário, ele vale mais como pontos de partida, como o projeto que gostaria de ter redigido há três anos quando comecei a desenvolver este trabalho. Recentemente Viveiros de Castro escreveu Metafísicas canibais como um livro sobre um livro que ele queria ter escrito, mas que nunca escreveu. Esta dissertação não é sobre uma outra dissertação não escrita, mas pode ser vista como uma miríade refratária de múltiplos projetos para outras dissertações nunca escritas.

Não se trata de projetos, no entanto, do tipo que escrevemos para entrar na pósgraduação ou para conseguir financiamento, projetos de concorrência, com número de páginas definido, em que racionalmente elencamos as atividades a serem realizadas, e em que ofinal já está dado de antemão, bastando apenas desenvolver o percurso argumentativo de modo sustentável e coerente. Como pensar um projeto em que o caminho não esteja dado e em que o 
que o rege não é a lógica da utilidade? E em que o tempo para a sua realização não é o da razoabilidade, mas o que o próprio projeto exige?

Esta dissertação acabou se tornando uma espécie de projeto(s) para um estudo que nunca acontecerá, porque a lógica institucional-acadêmica contemporânea não tem lugar (e tempo) para o tipo de estudo que a partir desta dissertação-projeto seria exigido. O que tínhamos planejado realizar no projeto original desta dissertação nunca, de fato, foi cumprido: estivemos sempre como que a nos preparar para a partida, para a viagem, a nos aprofundar nas dificuldades para a instauração do percurso que queríamos seguir. Esta dissertação é uma grande preparação para um salto que nunca foi dado, ela é o projeto que gostaríamos de ter escrito.

(Talvez por isso a presença do diário de Herzog no nosso último capítulo, uma alusão aos que juntaram o mínimo de coisas necessárias em uma mochila e partiram. Ele não escreveu nenhum projeto para fazer isso).

Isso não quer dizer que simplesmente nos desviamos do nosso "objeto", que simplesmente estivemos a divagar sobre qualquer outra coisa menos aquilo mesmo que delimitamos como sendo sobre o que gostaríamos de estudar: estivemos a todo o momento às voltas disso, circunvolvendo-o, às vezes tão perto dele que mal conseguíamos vislumbrar seus contornos.

Estou tão preocupado em chegar lá onde havia prometido que chegaria - a saber, a um aprofundamento dos elementos da cultura alemã, em especial do nietzschianismo russo e do fáustico, no romance $O$ Mestre e Margarida de M. Bulgákov, o que nos daria elementos para refletir sobre a relação entre realidade e fantasia no romance -, que resolvi seguir a sugestão da banca de qualificação e suprimir o que então era o primeiro capítulo da dissertação. Talvez estivesse tão pouco claro a que servia aquela preparação da preparação - aquela primeira reflexão tateante e entremadura que buscava ainda reconhecer os pressupostos a partir dos quais me propunha a provocar pressupostos - que chegaram a sugerir que ela fosse parar na conclusão. Leiam um trecho daquilo vocês mesmos:

Neste primeiro momento, ao analisarmos o contexto de elaboração do romance $O$ Mestre e Margarida, buscamos a questão que nos permitirá abordar o romance segundo um viés determinado. Trataremos de circunvolver em torno do debate já existente a respeito de Bulgákov. Muito se diz que "tudo" sobre Bulgákov já teria sido clarificado - há análises, por exemplo, minuciosas sobre cada aspecto da parte talvez mais repleta de mistérios e charadas, o romance de Pilatos. Mas não compartilhamos tal tese um tanto exagerada, como se a obra de Bulgákov fosse ainda mais canônica do que os cânones, que não se cansam de ser revisitados.

Mesmo que se acreditasse que tudo em torno de Bulgákov já tenha sido esclarecido, ainda assim restaria o que dizer sobre a obra. A própria ideia do esgotamento do que se pode dizer sobre este romance revela o seu ponto contrário, já que se trata de uma forma bastante simplista e superficial de abordagem de uma obra literária. E, ainda mais, uma obra que atenta 
inclusive contra a própria forma do romance, recheada de ambiguidades que não necessariamente estão aí para serem resolvidas.

Por esse motivo, é necessário encontrar uma questão adequada para a análise literária da obra, tal como se escolhe o melhor roteiro de um percurso. Assim, estamos preocupados, aqui, com esse "aplainar do terreno" que iremos percorrer ao longo do trajeto desta pesquisa.

Ao proceder desse modo, inevitavelmente nos depararemos com questões "metaliterárias", ou seja, questões prévias de análises de uma obra literária, as quais serão aludidas e desenvolvidas conforme a argumentação exigir. Com isso, expõe-se desde já a não filiação a priori desta investigação a nenhuma metodologia analítica, embora ao mesmo tempo seja impossível negar que ao longo da trajetória acadêmica acabamos nos vinculando e nos aproximando de determinados autores mais do que de outros: o que se espera é que, caso ao fim e ao cabo de nossa análise nos filiarmos aos "-ismos" típicos da ciência (e a literária não fica para trás), essa filiação só será possível de ser estabelecida a posteriori. Faremos isso através das escolhas de interpelação do texto literário que forem sendo tomadas conforme seja necessário um posicionamento teórico, sem que com isso deixemos de expor como, a cada passo de uma aparentemente despretensiosa análise literária de um determinado romance, o todo das questões teóricas da literatura, a "metaliteratura", a Literaturwissenschaft (ou ainda, a literatura enquanto Wissenschaft), está sempre posto em questão. Há, então, uma relação circular e de codependência entre o objeto e o método de análise que pretendemos manter em evidência em sua tensão originária.

Ao reler esta passagem, parece-me, contudo, que já nesse tatear novel estava de algum modo circunvolvendo em torno do que queria tratar. O que ainda me dá o que pensar é: como chegar lá ao centro do círculo - no-nada - sem antes lidar com o modo como até então se havia tratado aquilo de que eu queria tratar? Era preciso então lidar com os problemas e relações mais comuns operadas pela crítica: a vida de Bulgákov, sua biografia, seu autobiografismo. Era incômodo perceber como, mesmo os críticos do romance que mais defendiam a necessidade de um estudo formal e imanente do romance, acabavam baseando seus argumentos muitas vezes em acontecimentos da vida de Bulgákov. E isso era especialmente incômodo quando ia parar na política, pois, muitas vezes, um problema de interpretação era resolvido aludindo-se à posição política do autor ou a determinada atitude que alguma vez ele teria tomado ou a algo que ele teria dito.

Ao proceder desse modo, eu queria - contraditoriamente - propor uma abordagem imanente radical contra a imanência de conveniência desses críticos, sugerindo a possibilidade de que o próprio romance e os procedimentos nele contidos fossem capazes de dar as chaves segundo as quais compreender, por exemplo, os problemas políticos que estão presentes nele. É isso o que está em jogo em algumas das partes desta dissertação, talvez de modo mais evidente na análise do texto do crítico literário italiano Vittorio Strada (2009). Em outras palavras: ao realizar uma preparação da preparação da análise propriamente dita da obra, vi-me refletindo sobre o que é analisar uma obra literária, o que é imanência, como começar uma análise, e isso porque, em última instância, minha intenção era sugerir que mesmo nesse plano, ainda incapaz 
de conceder inteiramente validade para a abordagem que queria propor (a saber, neste plano da relação da obra com a vida privada de seu autor), já seria possível promover um deslocamento de perspectiva, ao subverter as soluções encontradas e perceber todo um fundo não questionado de pressupostos operando, o que me permitiria dar validade aos meus problemas.

Foi com esse intuito que empreendi uma análise da carta que Bulgákov envia a Stálin e à alta cúpula soviética em 1930. Tratando-a como uma espécie de manifesto de sua atividade literária, eu havia sugerido explosiva e provocativamente falar em autoficção e não autobiografia de Bulgákov, porque com isso - acreditava - estaria desviando os problemas, mostrando como as soluções que deram para eles eram - é claro - insuficientes, porque obviamente - não levavam em conta o problema que eu queria tratar. Fiquei tentado a usar esse termo, autoficção - embora nem tanto a partir da teoria que o cunhou, com o que queríamos igualmente provocar tal teoria -, porque Bulgákov não apenas traz elementos de sua vida pregressa para sua prosa, mas também de seu presente, e, a partir do procedimento paródico, como o pastiche, transforma diversas pequenas partes do em torno de sua realidade em um todo ficcional:

Quando os estudos não o trazem, é possível facilmente identificar, no mínimo, alusões a questões de sua vida pessoal ou do cotidiano de sua época. A "realidade" - tomada em seu sentido mais corriqueiro - adentra sua obra, caracterizada por forte presença de elementos fantásticos, em boa parte por meio de aspectos e procedimentos de ficcionalização de sua vida cotidiana. Embora esses não sejam os únicos procedimentos literários em jogo em suas obras Bulgákov, no limite, explora múltiplos deles, como o fantástico, o paródico, o trágico etc. -, os entendemos como sendo os recursos literários de onde sua atividade literária parte. $\mathrm{O}$ fantástico nele presente é já, nesse sentido, uma tomada de consciência e uma extremização desse procedimento de ficcionalizar a si mesmo. A ficcionalização de si mesmo, ou a autoficção ${ }^{1}$ que encontramos na plêiade de escritos bulgakovianos é um alvorecer em um tempo muito anterior, no entanto, desse recurso literário atualmente tão em voga (altamente influenciado por aquilo que ocorre em Paris). O termo cai-lhe tão bem, que poderia, ele próprio, tê-lo cunhado.

A exploração da forma autoficcional muitas vezes também significa extrapolar a inserção da realidade da vida pessoal do autor no romance, ficcionalizando aspectos desta. Isso pode ser visto na carta a Stálin mencionada, em que um texto não pode ser visto como uma busca por uma autorrepresentação.

\footnotetext{
${ }^{1}$ Ver: (KLINGER, 2006). Nos permitimos usar anacronicamente aqui esse conceito que, mais do que demarcar um gênero literário propriamente dito, aponta para questões inerentes a determinadas formas literárias. Optamos por fazer isso, em primeiro lugar, porque sempre vale a pena quebrar genealogias mais ou menos estabelecidas, ao mostrar que o tipo de problema que teoricamente teria surgido tão contemporaneamente, tendo uma relação tão direta com o individualismo e o mercado contemporâneo, já estava presente em outros períodos da História, e foi utilizado com outros propósitos. Em segundo lugar, porque Bulgákov quer intencionalmente embaralhar vida e ficção, evidenciando e explorando a multiplicidade de realidades e temporalidades do presente, caindo-lhe muito bem o termo. Em terceiro lugar, por fim, porque essa ideia nos permite pensar e analisar procedimentos literários centrais de Bulgákov.
} 
Fui alertado, contudo, para ao menos dois problemas do que eu estava fazendo ali: 1. A carta a Stálin não era um texto ficcional, portanto não poderia ser analisada como um manifesto de sua atividade estética; 2. Você não está realizando uma abordagem imanente do romance. Por causa do segundo ponto, resolvi suprimir o primeiro capítulo, e escrevi o agora primeiro capítulo, em que algumas das questões do primeiro capítulo anterior são tratadas a partir de outra perspectiva: a da relação paródica com o realismo socialista. Foi a mudança do projeto sobre uma imanência (que chamo aqui de) radical para a própria realização dessa imanência radical - embora ainda em projeto.

Radical no sentido de que em sua radicalidade ela seria capaz de romper com a própria necessidade de imanência, seria capaz de mostrar que a imanência sempre carrega consigo um antes da análise, que permanece inquestionado e que uma abordagem imanente que fosse de fato até as últimas consequências teria que trazer à tona, tornando-o seu objeto. E tudo isso motivado - e aqui era o pulo do gato - pelos próprios problemas do objeto que ela analisasse!

E aí o porquê de eu escolher $O$ Mestre e Margarida como centro da circunvolução (este centro entendido como uma reformulação do que convencionalmente se chama objeto de estudo). Ocorre que, ao longo desses três anos, eu tive a oportunidade de conversar com alguns colegas sobre esta dissertação e que, em uma dessas conversas, surgiu um questionamento que vale a pena ser pensado aqui: por que estudar Bulgákov e precisamente O Mestre e Margarida? Ele não é inovador, me disseram; seus procedimentos já haviam sido realizados por outros autores muito antes dele; ele vive de uma nostalgia do passado e - o que não foi dito, mas imagino que estava ali, vigorando como aquilo-que-não-deve-ser-dito - é, portanto, conservador na forma, e não apenas politicamente (talvez as duas coisas tenham de ser necessariamente paralelas numa concepção como esta).

Parece-me que essa não é uma questão que só eu tive de enfrentar, já que é possível entrever em algumas análises a busca por mostrar como, apesar de tudo isso, há algo de novo, de diferente ou de próprio em $O$ Mestre e Margarida. Um dos casos é, por exemplo, a relação de louvor com o passado literário na época do rompimento com as tradições que apontava para uma teoria na literatura da recepção literária e uma interpretação literária da literatura (como se isso não tivesse sido feito antes, como em Cervantes e Púchkin, duas grandes influências para Bulgákov); ou, outro caso, em relação à prosa bulgakoviana de modo geral, a criação de novos gêneros literários, como a ficção científica satírica, como meio de justificar o interesse acadêmico por esse autor e dizer: há o novo aqui, fiquem tranquilizados. 
Mas podemos ficar nesta mesma dissertação: o primeiro capítulo que trata (não apenas) da relação paródica com o realismo soviético é, entre outras coisas, uma tentativa de pensar a questão política em Bulgákov - contra talvez até mesmo as próprias convicções de Bulgákov a partir de dois conceitos, um de sua época, e outro que só apareceria décadas depois da publicação do romance: a sátira menipeia de Bakhtin e a parresía, investigada nos últimos cursos de Foucault da década de 1980 (com o que acabamos implicitamente sugerindo uma aproximação desses dois autores e a questão da revalorização da tradição cínica da filosofia antiga por meio deste e de outros autores pós-década de 1960 - bem como pensar porque e como Bakhtin (e para nós Bulgákov) já está falando disso nas décadas de 1920 e 1930, bem como o significado disso -, outro dos projetos nunca levados a cabo, mas que ao mesmo tempo estão presentes do início ao fim dessa dissertação).

Acreditava conseguir fugir do clichê que ronda as interpretações de Bulgákov quanto a este tema ao apontar a possibilidade de uma visada a meu ver mais imanente e coerente: aí poderia ter campo aberto para indicar outra possibilidade, a de que a forma do romance talvez não fosse tão conservadora se a sua posição política não o fosse (e, no limite, esse argumento funciona de modo invertido: se a forma não é tão conservadora, talvez os que observam um paralelo entre forma e sociedade possam ver que a posição política de Bulgákov não é tão fácil de definir como conservadora no âmbito dessa fala cotidiana que esvazia o sentido das palavras). Essa questão (mais ética que) política, aliás, perpassou toda a redação da dissertação, e voltou a aparecer segundo diversos aspectos ao longo das reflexões nos outros capítulos, como a da responsabilidade como nexo entre arte e vida no jovem Bakhtin, a relação disto com alguns aspectos de sua obra posterior e com uma das críticas que se fez à sua teoria da carnavalização, a saber, a de que ela seria um complemento do status quo e não seria capaz de levar a qualquer rompimento da norma.

Com o tratamento dessa questão, aponto para a possibilidade de pensar que Bulgákov, nesse romance, está tematizando a própria literatura como um discurso em relação com o poder e que, nessa tematização metalinguística, seria possível entrever a sugestão de uma relação entre discurso, verdade, realidade e poder por meio dos conceitos acima assinalados. Ao meu ver, é isso que uma abordagem imanente radical que levasse em conta a sociedade da época de Bulgákov seria obrigada a constatar: que o romance é capaz de reproduzir e problematizar na sua forma os aspectos talvez os mais agudos de dominação da sociedade e do tempo em que foi escrito. Esse problema por si só poderia ser (e deveria ter sido) tratado de maneira muito mais detida e pormenorizada do que eu tratei, já que, nos diversos momentos em que essa questão 
veio à tona, o que eu fiz foi antes justificar a validade de propor uma leitura desse tipo do romance- ou seja, a possibilidade de fazer um projeto que comprovasse metodológica e cientificamente essa tese -, do que comprová-la efetivamente como tal.

Mas será que há, em geral, algo mais em jogo do que projeto para projetos? Não seria toda tese sempre ainda um projeto de pesquisa? Esse tatear circunvolvente talvez possa sugerir o caráter desnecessário de empreender uma comprovação como tal, valorizando o momento do ato interpretativo provocador e explosivo, ou seja, da interpretação que aponte para a possibilidade de um deslocamento do olhar (sempre a metáfora da visão) da obra. Como se esta fosse a famosa figura pato-coelho, é como se desestabilizássemos a interpretação da obra como coelho, apontando que ela também pode ser um pato, mas não nos decidindo e comprovando que ela é um pato sem ser coelho, e sim valorizando o momento de indecisão que pode fazer dela nem-pato-nem-coelho, mas talvez ainda alguma outra coisa.

Os juízos estéticos negativos sobre $O$ Mestre e Margarida com base na suposta ausência de novidade - e, portanto, de singularidade - do romance estão, assim, entre outras coisas, no pano de fundo da ideia de que esta dissertação é um projeto de projetos, de que aqui se encontra uma preparação da preparação que circunscreve sem nunca chegar ao lugar prometido diferentemente dos Holzwege de Heidegger que não prometem lugar nenhum, mas sim clareiras esporádicas e, no final, uma volta ao mesmo lugar, o que evidencia-se, como se sabe, pela tradução francesa do título: Chemins, qui ne mènent nulle part. Ao mesmo tempo em que esse lugar está sempre ali, presente, tão próximo e ficcional que nem parece que se está nele (talvez porque ele seja esse sempre estar indo para, esse projetar-se de um caminho e de um problema que é o próprio problema em si).

Pois que, para mim, O Mestre e Margarida foi desde sempre um romance que valia a pena ser estudado pelo seu potencial de desestabilizar pressupostos, não só os da escolha por um método de análise literária, mas também os de questões que, como essa, como toda questão, já colocam a resposta no momento mesmo em que são formuladas, deixando entrever seus pressupostos. No caso dessa, critérios estético-valorativos como o da novidade. Sempre me pareceu que a leitura desse romance coloca em jogo precisamente mentalidades como a do novo na arte - e especialmente esta, moderna e da época de Bulgákov (mas talvez para alguém com essa mentalidade, o novo é o que opera a crítica moderna das práticas estéticas do romantismo e da tradição estética até tal época. E uma obra moderna como essa não seria capaz de ser percebida por alguém que pensa assim como nova por não querer ser nova, uma obra que, ao 
mesmo tempo, recupera o romantismo, uma tradição filosófica marginal como a cínica e que reflete sobre o moderno que ela mesma é, não querendo ser).

Por isso, por exemplo, em determinado momento, a aproximação (que poderia quase passar despercebida) com $O$ retorno do real de Hal Foster, o qual está pensando (não só) como a potencialidade do construtivismo russo só teria sido compreendida décadas mais tarde. E sua reflexão tematiza justamente a questão da realidade, central no romance de Bulgákov (segundo nosso projeto nunca realizado). Percebi em $O$ Mestre e Margarida uma capacidade em potência de autoquestionamento, de pôr em questão a todo momento os sentidos das leituras que se estão fazendo dele de tal modo que aquilo que se põe em questão é algo ainda mais profundo, a saber, a própria ideia de leitura, de literatura, de crítica, de realidade, de ficção. Interessava-me esse potencial crítico - mais do que de rompimento - dos mais variados âmbitos dessa literatura. Potencial que indicava a possibilidade de se pensar na relação entre filosofia e literatura de modo bastante significativo: parodiando o nome da instituição na qual desenvolvi esse estudo e o título do livro acima citado de Viveiros de Castro, diria que o romance apontava para um pensamento da possibilidade de metafísicas literariamente teóricas e comparativamente literárias.

Nesse sentido, parecia-me - e ainda me parece - que o romance poderia ser situado $n a$ marginália do modernismo e do moderno (uma espécie de contramodernismo moderno), sendo moderno (contemporâneo a si mesmo) sem querer ser, ao mesmo tempo nostálgico do passado literário e dobrado (uma reflexão) sobre (no e para além d)o moderno. No primeiro capítulo deixado de lado, pensei em questões próximas a isso a partir do conceito de morto-vivo:

Ser satírico na URSS é "ATENTA[R] CONTRA O REGIME SOVIÉTICO”, afirma Bulgákov, a seguir, na epístola a Stálin, citando uma passagem de um artigo de V. Blium contra ele. Tal afirmação já é bem diferente da anterior, a qual permitia a possibilidade de uma época em que fosse aceitável ser satírico na URSS. Essa diferença surge não apenas porque haveria na frase do crítico uma identificação de sua atividade com a URSS em si, mas também, podemos pensar, porque a utilização do recurso formal da sátira significava justamente postular uma continuidade entre o velho e o novo mundo. Em seguida, ele se questiona sobre sua admissibilidade na URSS, com o que faz justamente a contraposição entre uma URSS que fosse equivalente ao Comitê Central de Repertórios (pode ser pensado como uma em que o projeto de poder deste vencesse) e uma outra. Seria este o seu auto-"retrato literário" (ANDRADE, 2002, p. 142) - ou automitologia de si -, no sentido da instauração de uma 'representação' de si em um texto 'extraliterário', procedimento oriundo de seu expediente autoficcional?

Por conta de todos esses motivos, Mikhail Afanássevitch Bulgákov conclui que "não há esperanças para minhas obras" e afirma que, "para mim, a impossibilidade de escrever equivale a ser enterrado vivo". O que quer dizer, ao que parece, exatamente o que ele diz a seguir em letras capitais: "PEÇO AO GOVERNO DA URSS ORDENAR, EM CARÁTER DE URGÊNCIA, QUE EU DEIXE O PAÍS EM COMPANHIA DE MINHA MULHER LIUBOVA EVGUÉNIEVNA BULGÁKOVA" (ANDRADE, 2002, p. 143). 
Mesmo sendo impossibilitado de ser escritor e estando, por isso, "enterrado vivo", Bulgákov dá mostras de como ele ainda poderia ser útil ao seu país - afinal, ainda está, para todos os efeitos, fisicamente vivo -, caso o "senso humanitário do poder soviético" não possa agir com "generosidade" e "deixar-me em liberdade". Trata-se de trabalhar em um teatro, onde ele já havia demonstrado ser um "especialista de excepcional qualidade". Neste momento de sua carta podemos ver como, em certa medida, parece ser mais odioso a Bulgákov sair da Rússia do que ser impossibilitado de ser escritor. Isso porque sair da Rússia significaria o mesmo que justamente não poder mais escrever, e ainda implicaria um afastamento da realidade do "seu" povo; enquanto que se manter na Rússia, mesmo que "enterrado vivo", mas podendo trabalhar em algum lugar, permitiria a ele, como vimos que de fato permitiu, escrever literatura e alimentar a expectativa de renascer, isto é, ser publicado, em vida ou, ao menos, após a morte.

Talvez o que seja mais próprio de Bulgákov dentro mesmo da tradição do romance russo moderno seja precisamente esse aspecto de "morto-vivo", que pode assumir diferentes sentidos: misturas de realidades, a relação entre o novo e o velho na Rússia, a problematização da maneira pela qual a tradição é absorvida, renovada e passa a vigorar a cada vez no novo, que é cada nova obra e a forma fragmentada em diversos romances de seu último romance.

Embora utilize o capítulo suprimido como uma maneira de refletir sobre esse estudo tal como o faz João Moreira Salles em relação ao longa que nunca produziu sobre o mordomo de sua família, no filme que recebeu o mesmo nome deste, Santiago (2007) -, este preâmbulo não é o capítulo sobre o capítulo suprimido e eu também não vou compará-lo ao homúnculo de Wagner, erroneamente atribuído a Fausto pelo personagem de Bulgákov. O que eu pretendia era, sinceramente, prevenir as expectativas do leitor, avisando que ele ficará frustrado caso espere que eu, como um guia de viagens literárias, o leve até algum lugar. Esta dissertação é constituída de fragmentos que se relacionam entre si de diversos modos (uma coisa leva à outra como em um pensamento que segue uma lógica não tão clara e distinta como a lógica tradicional), mas que se complementam, dialogam entre si, respondem uns aos outros e a questões que ficam no pano de fundo, instigando a reflexão. Igualmente, são muitas as temporalidades de escrita e de revisão desses fragmentos, sendo também muitas as coisas que foram sendo maturadas no processo de escrita e reescrita, de supressão e introdução desses fragmentos, o que pode contribuir ainda mais para uma impressão fragmentária e tateante.

Falo disso não como uma desculpa prévia ao leitor, mas como uma enunciação do tom que escolhi: sempre que possível, adotei como prática a indicação, por meio de notas, de leituras em que seria possível aprofundar os temas analisados, tangenciados, porque inesgotáveis, ainda mais em uma época em que tanto se produz academicamente. Em contrapartida, é também preciso deixar bem claro que em nenhum momento tive a preocupação de realizar uma exposição que facilitasse ou normalizasse o romance $O$ Mestre e Margarida, para que fosse melhor entendido pelo público em geral. Isso não quer dizer que não procurei ser o mais claro possível em minhas formulações, mas sim que não me guiava por uma vontade de explicar, 
simplificar e resolver a obra e as questões que ela coloca, mas, antes, por uma vontade de explorar, vivenciar e expor a complexidade e riqueza desse romance.

E aqui posso explicar o porquê da epígrafe, uma vez que ela enuncia e evidencia os perigos opostos deste empreendimento: o excesso e a ausência de rigor, a ideia de que era preciso justificar tudo logicamente segundo um método nos mínimos detalhes, e a ideia de que quanto mais fragmentado, desorganizado e tateante, melhor ficaria. Achar um ponto médio entre esses dois impulsos nem sempre foi e é fácil.

A epígrafe também põe outra questão que esteve no pano de fundo desta dissertação e que nem sempre fica evidente, a saber, a do pensamento brasileiro, nem tanto como uma questão nacional, mas local (ou, como diz Safatle, nem tanto como "estilo", mas como "campo" ${ }^{2}$ ): de certa forma, eu gostaria de que esta dissertação fosse entendida como uma resposta ao e uma voz do ambiente intelectual uspiano e quem sabe brasileiro, e não uma pesquisa somente extremamente específica ou técnica, preocupada somente com um estudo de Bulgákov por Bulgákov mesmo. Por estar antes aqui, neste ambiente, na instituição da teoria literária, e não ali, numa discussão específica dos estudos eslavófilos, em primeiro lugar, o não completo domínio da língua russa não foi um impeditivo para o andamento da pesquisa; e, em segundo lugar, boa parte do que foi escrito foi sendo construído, pensado e organizado em grupos de estudo, conversas, apresentações e aulas. Não se trata de uma conveniência, de fazer um mesmo

\footnotetext{
${ }^{2}$ Vale a pena recorrer a uma longa citação de Safatle, para perceber ao mesmo tempo a evolução da questão em torno de uma filosofia brasileira e a persistência de certos impasses sobre como se dar um ambiente de discussão que se possa chamar propriamente de filosófico, os quais já Flusser havia percebido em janeiro de 1967 no texto que citamos (e teria sido por conta de sua identificação como "de direita" graças a matiz heideggeriana de onde pensava a filosofia, embora não se definisse, e no momento do golpe de 1964 a definição política ter se tornado obrigatória, que, parece-me, suas críticas a perigos próprios da filosofia acadêmica ter sido descartada tão facilmente, o que ao mesmo tempo é sinal e causa da dificuldade de se formar um campo propriamente dito de discussão filosófica, o mesmo que Safatle no texto a seguir vem reivindicar fazendo alusão justamente à figura do filósofo não especializado, não meramente técnico, o desejado na época de Flusser pela esquerda e que, ironicamente, hoje parece cada vez mais ser visto como um problema a ser enfrentado (ver (MENDES, 2000). "Tudo isto nos leva a uma pergunta: para que serve e a quem interessa insistir atualmente na existência de 'filosofias nacionais'? Elas servem para, de fato, descrever o jogo de forças imanentes a experiências filosóficas singulares, experiências estas que se fazem, na verdade, através não do respeito, mas da desqualificação de tradições, do salto improvável em direção ao que não andava junto (como Deleuze e sua 'tradição' composta pelo inglês Hume, pelo francês Bergson, pelo holandês Spinoza e pelo alemão Nietzsche)? Ou elas servem para reiterar a existência de um espírito que só existe para dar alguma organicidade à monstruosidade institucional chamada de Estado-nação com seu símile intangível e 'imaterial', a saber, a 'cultura nacional'? É sempre possível recusar esta maneira um pouco selvagem de eliminar o problema apelando à irredutibilidade de um fato empírico sabido de todos. Pois queiramos ou não há filosofia francesa, alemã e anglo-saxã. Há livros sobre isto, há centros de pesquisa com tais nomes, há pessoas que reivindicam para si certo pertencimento, há disputas pela influência. É verdade, há tudo isto, mas é sempre possível se perguntar: que tipo de realidade é esta? Pois é fato que há bem uma realidade sociológica, mas talvez ela interesse mais à sociologia das ideias do que à filosofia propriamente dita. Pois ela talvez não descreva um 'estilo' ou o espaço de produção de singularidades de pensamento. Talvez ela descreva simplesmente um 'campo', ou seja, um conjunto de instituições, de meios de difusão, de regimes de adesão e exclusão, de promessas de benefícios simbólicos e materiais, de debates que levam os mais novos a repetirem práticas dos mais antigos caso respeitem a normatividade que até agora se consolidou." (SAFATLE, 2016).
} 
texto servir a dois propósitos; muito diversamente, adotei esse procedimento como estratégia, com a intenção de valorizar e implicar os momentos comunitários da vida acadêmica nos momentos de solidão, de leitura, estudo e escrita. E não como uma crítica à solidão da vida acadêmica, mas sim como um modo de mostrar a relação entre os problemas específicos com os quais me deparava no estudo de $O$ Mestre e Margarida e o ambiente intelectual circundante.

Daí também a variação entre a primeira pessoa do singular e a do plural: nos momentos em que considero afirmar algo singular, talvez íntimo, ou ainda algo sobre o que eu esteja duvidoso e passível de contraposição, preferi usar o singular (como agora); já nos momentos em que adoto um tom mais impessoal, performativo, e na sequência argumentativa, preferi o uso da primeira pessoa no plural, não como uma imposição de aceitação do que foi dito pelos outros contidos no "nós", mas por sentir a possibilidade de ter as veredas de meu pensamento acompanhadas por outros. Talvez essa variação seja fruto de uma tentativa de manter a tensão entre os momentos solitários e os compartilhados deste estudo. Tenho consciência, no entanto, do tabu que envolve essa questão e que deveria ter escolhido uma ou outra opção para normativizar o texto, mas temo que não seria possível fazer isso sem perder sua consistência, de modo que deixo feita mais essa ressalva ao leitor (não mais) desavisado.

Assim que dividi esta dissertação em três partes principais. Na primeira, inicio uma análise da obra a partir do seu primeiro capítulo, procurando pensar a relação do romance com sua época a partir de uma aproximação com a estrutura do romance do realismo socialista. Essa aproximação revela um jogo intrincado de inversão e distanciamento paródico dos elementos característicos desse gênero, que leva à reflexão e a uma abertura ao filosófico, a qual procuro pensar a partir da sátira menipeia de Bakhtin e da parresía de Foucault.

Na segunda parte, prossigo com a análise do romance, preocupado com o entre, o espaço vazio da passagem de um capítulo a outro, que tratei segundo duas de suas questões formais: não mais a proximidade com o realismo socialista, mas com o elemento fáustico, e também com a relação entre o romance propriamente dito e o romance dentro do romance. Por meio das questões que essa análise da relação com o elemento fáustico suscita, acabo enveredando numa investigação sobre a noção de paródia que é utilizada em sentidos muito diferentes pelos autores com quem estava dialogando. Em nenhum momento quis erguer uma nova teoria da paródia que vigorasse ao lado das outras, mas sim unicamente buscar os elementos que pudessem ressoar e ser significativos para a interpretação do romance, como certa concepção de história e de responsabilidade que poderia estar vigorando na noção de sátira menipeia de Bakhtin. 
De certa forma, adentrar nessa questão lança luz às análises da seção anterior. Percebemos ainda que uma das principais funções do elemento fáustico consiste em uma universalização dos problemas morais, éticos e políticos para os quais o romance se abre, fazendo com que a relação entre poder e literatura não fique circunscrita apenas à realidade soviética, mas ressoe como um problema humano em geral; já a estrutura de boneca russa do romance pareceu-nos ter em vista promover o distanciamento crítico e a atividade reflexiva do leitor a respeito, por exemplo, dos aspectos materiais do romance em sua relação com o poder e com o ético.

Na última parte desta dissertação realizei uma análise do romance dentro do romance (que, vale repetir, em nenhum momento tive a pretensão de que fosse exaustiva e esgotasse os problemas ali contidos), buscando apontar a presença de elementos nietzschianos para a representação literária da Paixão de Cristo, não como mera erudição, mas como modo de reforçar e aprofundar algumas das principais hipóteses que desenvolvi ao longo deste estudo. Esse aprofundamento seguiu até a hipótese de que talvez Bulgákov tenha promovido um experimento literário de contrapor métodos de representação literária - o que chamei (talvez de modo exagerado) de polifonia de métodos de representação da realidade -, com o que revisitamos de modo mais aprofundado questões de que tratei no primeiro capítulo. 


\section{Entremeios da filosofia e da literatura}

Não são poucos aqueles que se debruçaram sobre a relação entre literatura e filosofia, principalmente nos últimos tempos, o que não significa sobremaneira estar esta questão pacificada. Meu interesse no tema vem do problema da relação entre a filosofia e seus entremeios, sejam as filosofias ditas não ocidentais, sejam outros tipos de discursos que entremeiam as filosofias ditas tradicionais, como o discurso literário. Nesse sentido, entrevi em O Mestre e Margarida um modo muito particular e pouco explorado de pensar essa relação, pois: (a) ele traz em seu bojo uma relação profunda com um ambiente de discussão filosófica não ocidental que foi chamada de nietzschianismo russo - ao mesmo tempo ligado às vanguardas russas, ao renascimento religioso russo que ocorreu na virada do século, durante e após a Revolução Russa, à tradição literária russa (principalmente Dostoiévski) e a alguns aspectos do discurso oficial russos e soviéticos (o que não significa ler o romance a partir de Nietzsche e do nietzschianismo, mas em relação, discussão e antagonismo com estes); (b) a relação com esta tradição no romance leva especialmente ao desenvolvimento e aprofundamento do significado e sentido da paródia que estão ligados intimamente a uma reflexão sobre a relação entre literatura e filosofia, a partir da literatura, de um modo muito particular.

Que tipo de crítica e de pensamento pode haver em uma obra literária? É ela capaz de pensar a si mesma a partir do entremeio do pensamento dito racional em que está? Que tipo de procedimento formal é preciso para que isso aconteça? É ela capaz de pôr em questão esses mesmos procedimentos que a constituem? Se a literatura representa o real, haveria algum modo de a literatura representar o real avançando para uma reflexão sobre a representação e a realidade? Seria possível isso ocorrer sem que esta reflexão seja (somente) tematizada como um sobre o que a representação do real se dá, mas também como um a partir de que os índices de verossimilhança se constroem e moldam a obra?

Vale ressaltar que, de fato, o lugar particular do romance dentro dessa questão da relação entre filosofia e literatura que entrevi - e por isso desejei estudá-lo - se constitui expressamente a partir não meramente de si mesmo, mas da relação que estabelece com essas linhas que o transpassam (da tradição e de problemas herdados dela); o que significa dizer que este lugar singular, difícil, do romance somente pode ser observado por uma abordagem que explora a exploração do lugar entremeado de $O$ Mestre e Margarida seja dentro da literatura russo- 
soviética até então, seja no contexto mais geral da literatura e filosofia ocidental. A particularidade do romance, nesse sentido, só pode ser vista a partir da sua relação com a tradição e com o (seu) presente. Ela não é uma particularidade em si, mas na medida em que estabelece relação com estas duas instâncias, e em que, a partir destas relações estabelecidas, promove uma abertura de linhas de fuga possíveis, antes não aparentes nessas instâncias: sua particularidade pode ser entendida como uma espécie de ponto nodal, de prisma de inflexão, capaz de apontar para diferentes possibilidades de tradição antes veladas. Escolhi aproximá-lo, do lado da tradição, de Goethe e Gógol - este como principal representante da literatura russa; do lado do presente, de Bakhtin, os realismos socialistas e o nietzschianismo russo. Com isso, esperava apontar o fundo dos problemas internos de $O$ Mestre e Margarida, como o recurso à paródia e o problema da ligação entre os romances. Ao tematizar (formalmente!) os entremeios, as margens, as passagens e viradas, o romance tematiza a si mesmo, a seu tempo e à tradição literária russa. Ou poderíamos dizer o inverso: ao tratar de questões locais - de si mesmo, de seu tempo e da tradição literária russa e ocidental -, O Mestre e Margarida abre-se a questões universais, como a noção de humano, de verdade, de fantasia e de real.

No que se segue, então, não há qualquer pretensão de esgotar a análise da obra e abarcar a totalidade de problemas que ela desenvolve e que já foram tematizados nas reflexões sobre a relação entre filosofia e literatura, entre filosofia e (alguns de) seus entremeios, mas de analisar essa relação a partir e no centro circunvolutivo de $O$ Mestre e Margarida. 


\section{“Isto não pode ser verdade" - a ficção (humana): a fantasia como sátira nos tempos dos realismos socialistas}

O primeiro capítulo do romance $O$ Mestre e Margarida, "Nunca fale com pessoas desconhecidas", narra uma conversa na Moscou da "alta cultura" entre dois membros da intelligentsia soviética que, em determinado momento, é interrompida por um estrangeiro de boca "um tanto torta". A conversa diz respeito aos motivos pelos quais a Mikhail Aleksandrovitch Berlioz, dito presidente da MASSOLIT (uma das maiores associações literárias de Moscou no romance), não agradou a composição encomendada por ele a Ivan Nikolaievtich Poniriov - de pseudônimo Biezdomni -, de um poema sobre Jesus Cristo, por ocasião - presume-se - do feriado pascal.

Em seu aspecto geral, a relação entre os dois homens com aparência de literatos tem algo dos diálogos entre mestre e aprendiz da tradição ocidental. Nesse diálogo situado na praça do Patriarca - em plena URSS presumivelmente stalinista -, Berlioz e Biezdomni conversam sobre a existência da pessoa histórica de Jesus. Aqui, a relação mestre-aprendiz se assemelha à de uma aula expositiva e objetiva: Berlioz discorre largamente, recorrendo a um conhecimento histórico enciclopédico e objetivista, sobre a historicidade das religiões, comparando, por exemplo, a cristã a muitas outras, visando com isso demonstrar a inexistência histórica de Jesus. É possível perceber que nela não há uma produção ou construção conjunta de conhecimento, não há questões que inquietam aprendiz e mestre, não há, no limite, atividade do aprendiz, ele passivamente se informa de fatos históricos por Berlioz, o mestre formador:

Mas Berlioz queria demonstrar ao poeta que o mais importante não era o fato de ter sido Jesus bom ou mau, mas sim, saber que esse Jesus não existiu como pessoa e que tudo o que se fala dele não passa de simples invencionice, de um mito ordinário.

Cumpre assinalar que o redator era uma pessoa culta e se referia muito habilmente nas suas considerações a historiadores da Antiguidade, por exemplo, o famoso Fílon de Alexandria e o brilhante erudito Flavius Josephus, que jamais tinham mencionado a existência de Jesus. Mikhail Aleksandrovitch deu prova da sua grande erudição quando disse de passagem ao poeta que o trecho do Décimo Quinto Livro, do Capítulo 44, dos famosos Anais de Tácito, em que se fala da execução de Jesus, não passa de uma interpolação falsa, inserida mais tarde.

Tudo que o redator dizia era novo para o poeta e ele ouvia atentamente Mikhail Aleksandrovitch, tendo cravado nele os seus vivos olhos verdes. (BULGÁKOV, 1992, p. 14-5). 
Então, se é possível ver nessa argumentação erudita, mas informativa, a forma de um diálogo cuja estrutura evoca algo da dos diálogos entre mestre e aprendiz, temos de perceber também como Bulgákov faz com que este diálogo instaure uma relação de poder e dominação entre mestre e aprendiz. Ela fica caracterizada e acentuada pela incapacidade (formativa) de Biezdomni de averiguar por si mesmo a validade das informações proferidas por seu mestre.

Berlioz, assim, não apenas é o representante concreto da erudição, mas também dos interesses culturais e literários do poder soviético-stalinista (o que nunca é nominado no romance). Podemos perceber isso pelo teor de seu ensinamento: Biezdomni não deveria ter criticado Jesus Cristo, mas sim ter sugerido que Jesus Cristo - e o poder que representa - nunca existiu como pessoa concreta. Porém, o erro de Biezdomni não faz dele um outsider do poder soviético. Sua figura representa o tipo de agente cultural que esse poder, em determinado momento, quis formar para preencher o vácuo cultural que as mudanças sociais e políticas na Rússia estavam promovendo ${ }^{3}$.

Com efeito, a relação entre o formado, Berlioz, e o formando, Biezdomni, evoca a categoria do diálogo mestre-aprendiz, mas tem a especificidade do momento histórico do romance $O$ Mestre e Margarida, podendo ser vista como um dos desdobramentos ulteriores do problema enfrentado pelos populistas russos a partir do sexto decênio do século XIX ${ }^{4}$ cristalizado, por exemplo, no romance Pais e filhos (1862), de Turguêniev. Ao se colocar em perspectiva histórica o eco de uma estrutura dialogal mestre-aprendiz, pelo que é possível desnudar algumas referências determinantes que antes estavam veladas, conseguimos perceber que a escolha por iniciar o romance com ela não é sem propósito, mas indica uma preocupação elevada - embora aparentemente velada, cabendo ao leitor desnudá-la - com os desdobramentos históricos, principalmente com aqueles que geraram as formas de dominação cultural da realidade soviética que é representada na obra.

Além de com isso situar historicamente o romance - dotar de um tempo e espaço específicos: a década 1930 soviética em Moscou -, a ênfase na situação dialogal pode dispensar uma visada do romance de Bulgákov quanto à sua relação com os poderes vigentes alternativa à interpretação que privilegia os aspectos filosóficos e morais da obra. Não pode mais se tratar de interpretar a realidade soviética a partir de arquétipos como o do demônio, ou em termos do

\footnotetext{
${ }^{3}$ Para uma análise mais detalhada sobre a relação complexa e muitas vezes ambígua entre os escritores proletários promovidos pelas políticas culturais soviéticas em determinados períodos e o poder soviético durante as primeiras décadas da URSS, ver (ANDRADE, 2010a, p. 154 e ss.).

${ }^{4}$ Para um desenvolvimento completo das múltiplas complexidades históricas do período e seus desdobramentos até a Revolução Russa, ver (BERLIN, 1988).
} 
bem e do mal. Isto posto, a ênfase na prática dialogal não é de modo algum alérgica a toda problemática moral e filosófica presente na obra, por considerá-la "teologista" ou outro pecado similar. Mas quando vista de perto, essa ênfase no dialogal pode ser tomada como uma intensificação do desejo de discutir a problemática filosófica do romance, na medida em que ela surge de uma análise de sua forma estética, reformulando os termos ou o terreno em que tal problemática está posta.

Diferentes capítulos do romance se estruturam em forma dialogal, sendo que alguns deles parecem ainda estar estruturados justamente em diálogos formativos, ecoando a relação mestre-aprendiz, como o diálogo entre Jeshua e Pôncio Pilatos, no romance dentro do romance, e o entre o Mestre e Biezdomni (Sem-casa), no quarto do sanatório. O contraste entre eles revelará a existência de um modelo de formação que em alguns casos é preenchido e, em outros, não. A comparação entre as situações dialogais mestre-aprendiz poderá nos indicar um movimento interno do romance, ao apontar o preenchimento ou não dos critérios pelos quais se dá de modo pleno ou não a função de mestre e de aprendiz.

A fim de encontrar tais critérios, é preciso introduzir uma segunda hipótese-tese desse percurso: será que esse aspecto formativo do primeiro capítulo de $O$ Mestre e Margarida nos permite considerá-lo uma paródia do romance realista socialista? Se for possível, conseguiremos determinar mais claramente os polos do caráter formativo no romance, já que o romance do realismo socialista pode ser visto também como um caso especial de romance de formação:

The Socialist Realist novel might in effect be seen as a politicized variant of the Bildungsroman, in which the hero achieves greater harmony both within himself and in relation to his society. Such a comparison cannot be taken very far, however, because the Socialist Realist novel is so highly ritualized that the hero's progress is neither individual nor self-valuable ${ }^{5}$. (CLARK, 2000, p. 16-7).

Além disso, a autora também diz que "in Bolshevik fiction of the twenties one can find embryone examples of this developing trend in the conventional mentor-disciple pattern" 6 (CLARK, 2000, p. 144). A formação em O Mestre e Margarida passa pelo fato de o herói-

\footnotetext{
5 "O romance realista socialista pode, com efeito, ser visto como uma variante politizada do Bildungsroman na qual o herói atinge uma harmonia maior tanto consigo mesmo como em relação à sua sociedade. Tal comparação não pode, contudo, ir muito longe, já que o romance realista socialista é tão altamente ritualizado que o progresso do herói não é nem individual nem autovalorativo." (Tradução nossa).

6 "Na ficção bolchevique dos anos 1920 é possível encontrar exemplos embrionários em desenvolvimento dessa tendência no padrão convencional mentor-discípulo.” (Tradução nossa).
} 
aprendiz, Biezdomni, atingir de algum modo uma desarmonia com sua sociedade, bem como desenvolver certa individualidade e autonomia perante ela.

Biezdomni irá encontrar sua formação não por meio de Berlioz, mas em situações também em forma de diálogo mestre-aprendiz ao longo do romance, uma vez que a formação soviética personificada pelo crítico e funcionário soviético tenha se mostrado incapaz de cumprir sua finalidade com a chegada do demônio. Talvez um modo de pensar essa finalidade seja o percurso que vai do dogmatismo - a formação de Berlioz -, passa pela experiência negativa - a entrada do demônio e o contato com a obra e com as palavras do Mestre - e chega à renovação de visão de mundo - no epílogo, já professor universitário de história ${ }^{7}$. Podemos ver em jogo tal desenvolvimento, nesta passagem, já do trigésimo capítulo, quando Ivan Biezdomni começa a renovar sua visão de mundo após seu contato explosivo com o demônio:

Ivanuchka jazia imóvel, da mesma forma que na ocasião em que observara pela primeira vez a tempestade naquela casa onde havia encontrado seu repouso. Mas não chorava, como naquela vez. Quando escrutou bem o vulto escuro que irrompeu no seu quarto, da sacada, ele se levantou, estendeu as mãos e disse com alegria:

- Ah, é você! E eu estava aqui à sua espera. Até que enfim você chegou, meu vizinho.

O Mestre respondeu a isso:

- Estou aqui! Mas infelizmente não posso ser mais o seu vizinho. Vou embora para sempre e vim aqui apenas para despedir-me.

-Eu sabia; já o adivinhara - respondeu Ivan [...] (BULGÁKOV, 1992, p. 403).

Ivan Biezdomni é Ivan Nikolaiev Poniriev - para alguns ${ }^{8}$, o verdadeiro herói do romance, por ser o personagem mediano de modelo aristotélico que passa por uma transformação na luta entre as instâncias de "bem e mal" -, que cunhou um codinome artístico tal como muitos escritores popúttchik ${ }^{9}$ (o mais famoso deles, Maksim Gorkii, Máximo, o amargo), Bezdomnii, literalmente "Sem-teto" (e, em uma tradução espanhola, Desamparado ${ }^{10}$ ).

Ainda quanto ao nome de Ivan, entre os comentadores da obra, desprende-se enorme esforço para compreendê-lo a partir de referências à vida de Bulgákov. Fala-se de dois nomes

\footnotetext{
${ }^{7}$ Modelo bastante caricato do que Gerd Bornheim considera ser o percurso do desenvolvimento da experiência filosófica individual.

${ }^{8}$ Ver: (WEEKS, 1996).

${ }^{9}$ Popúttchik, companheiro de viagem, foi como Trotski chamou os escritores não filiados ao partido, mas que poderiam contribuir para a formação da nova cultura proletária, em seu Literatura e Revolução (1923).

${ }^{10}$ Ver (BULGAKOV, 1990).
} 
existentes na época: um Efim Alexandrovich Pridvorov e um Alexandre Ilitch Bezimenski ${ }^{11}$. Para além dessas referências extratextuais, pode-se dizer que a escolha deste pseudônimo tem relação com o lugar de Ivan na trama do romance. Isso por ser ele um sem-teto no sentido de que lhe falta uma compreensão autêntica do mundo, uma Weltanschauung, tratando-se simplesmente de alguém sem convicções próprias. Se analisarmos a questão espacial nas obras de Bulgákov (WEEKS, 1996, p. 143 e ss.) de modo a aplicarmos essa discussão a Biezdomni, então poderemos pensar que seu nome significa "homem sem espaço interno". Aos olhos de Bulgákov, isso poderia soar como uma metáfora do homem soviético em geral, e é significativo que seja justamente esse personagem que sofre as maiores mudanças no decorrer do texto.

A partir disto, Ivan pode consistir em um personagem paródia do realismo socialista, na medida em que a trama de $O$ Mestre e Margarida pode ser vista como a passagem de suas ações espontâneas a ações que ele toma de modo consciente. Essa passagem era a trama dos romances do realismo socialista, segundo Clark ${ }^{12}$ (CLARK, 2000, p. 3-24). Mas, aqui, a consciência que Ivan adquire com a ajuda do demônio não é a da conformação ao imaginário oficial do realismo socialista, mas a da capacidade de refletir e assumir uma postura crítica em relação à realidade que esse método de representação literária fantasiava como sendo o próprio real.

Podemos tentar entender isso vendo o quanto Ivan é, em um primeiro momento, moldado segundo essa (dia)lógica. Após a decapitação de Berlioz, Ivan sai correndo atrás da trupe diabólica que, nesse momento, ele considera ser composta por agentes estrangeiros que previram e causaram a morte de Berlioz. Nessa correria por Moscou, Ivan age de modo espontâneo. Ele tem atitudes não refletidas nem orientadas por consciência política e que são anárquicas e descoordenadas. O episódio todo pode ser visto, nesse sentido, como, ao mesmo

\footnotetext{
${ }^{11} \operatorname{Ver}($ SOKOLOV, 2006, p. 241).

12 "The subtext that does shape the master plot is another fundamental idea of Marxism-Leninism, one that is a somewhat déclassé and more abstract version of the class-struggle account of history. In this version, historical progress occurs not by resolving class conflict but through the working-out of the so-called spontaneity/consciousness dialetic. In this dialectical model, 'consciousness' is taken to mean actions or political activities that are controlled, disciplined, and guided by politically aware bodies. 'Spontaneity', on the other hand, means actions that are not guided by complete political awareness and are either sporadic, uncoordinated, even anarchic (such as wildcat strikes, mass uprisings etc.), or can be attributed to the workings of vast impersonal historical forces rather than to deliberate actions." (CLARK, 2000, p. 15). "O subtexto que conforma o enredo principal é outra ideia fundamental do marxismo-leninismo, uma ideia que é uma versão de certo modo marginal e mais abstrata da narrativa histórica da luta de classes. Nesta versão, o progresso histórico acontece não pela resolução do conflito de classes, mas através do exercício da dialética espontaneidade/consciência. Nesse modelo dialético, 'consciência' é tomada como ações ou atividades políticas que são controladas, disciplinadas e direcionadas por corpos politicamente conscientes. 'Espontaneidade', por outro lado, significa ações que não são completamente direcionadas por consciência política e que são esporádicas, descoordenadas, até mesmo anárquicas (como greves não autorizadas, revoltas da massa etc.), ou que podem ser atribuídas mais aos trabalhos de vastas forças históricas impessoais do que a ações deliberadas." (Tradução nossa).
} 
tempo, a experiência concreta da experiência negativa - a dúvida que coloca a normatividade às avessas - e a frustração da capacidade de lidar teórica, discursiva e conscientemente com a situação, como fica evidente quando, posteriormente, o personagem tenta relatar racional e articuladamente o ocorrido. Nessa espécie de queda, vai parar num sanatório por causa desse seu comportamento anarquista e descoordenado. O sanatório vale como um ambiente em que poderá ter tratada a sua espontaneidade com injeções, e, por meio de sessões terapêuticas, desenvolver sua consciência e capacidade reflexiva.

Sanatório - lugar para onde iam os dissidentes do regime quando não eram mortos ou enviados aos gulags, e ambiente que vale como uma espécie de universo paralelo (ou protegido) em relação aos jogos e vontades de poder do mundo exterior, lugar em que a efetividade do discurso é ao mesmo tempo permitida e esvaziada, lugar favorável para a reconstrução das bases conceituais de Ivan após o trauma da experiência negativa. Tendo sido atingido pelo gênio do mal da dúvida - momento negativo que inexiste na trama do realismo socialista -, Ivan agora encontra o personagem Mestre (ou é o Mestre que encontra Ivan?). É nesse momento que Ivan tem com o Mestre um diálogo que se assemelha ao do tipo mestre-discípulo, cujo caráter fica enfatizado em um momento posterior da trama, quando o Mestre volta ao sanatório para se despedir pela última vez de Ivan, e diz: “- Adeus, discípulo - disse o Mestre quase inaudível” (BULGÁKOV, 1992, p. 405). Esse primeiro diálogo entre Ivan e o Mestre tem características bem diversas das do diálogo anterior com Berlioz. Podemos constatar isso na passagem a seguir:

- Profissão?

- Poeta - respondeu Ivan, não se sabe por que, a contragosto.

- Oh, que tremenda falta de sorte eu tenho! - exclamou ele, mas se apercebeu imediatamente da indelicadeza que cometera, pediu desculpas e perguntou: E o seu nome, qual é?

- Biezdomni.

- Ai, ai... - disse o visitante franzindo a testa.

- Não gosta das minhas poesias? - perguntou Ivan com curiosidade.

- Acho-as definitivamente execráveis.

- E quais são as poesias que leu?

- Não li nenhuma das suas poesias! - exclamou nervosamente o visitante.

- Como pode falar, então?

- Ora bolas... - respondeu o visitante - como se eu não tivesse lido as poesias dos outros! Por outro lado... talvez aconteça um milagre! Está bem, estou pronto a acreditar na sua palavra. Diga-me o senhor mesmo, são boas as suas poesias?

- São monstruosas! - disse de repente Ivan, corajosa e francamente. (BULGÁKOV, 1992, p. 147-8). 
Se o Mestre avalia as poesias de Biezdomni de modo negativo - mesmo sem as ter lido! -, tal como Berlioz, a diferença aqui está em o critério ser outro: não o conteúdo da poesia (afinal, não se está falando de nenhuma poesia específica), mas a sua forma (e em especial a de poesia que autores com codinomes como Desamparado produzem). Outra diferença reside em que Ivan é capaz de dar um juízo sobre a forma da poesia, quando em sua conversa com Berlioz ele se colocava em uma posição inferior, incapaz de acompanhar e de avaliar o conteúdo de sua própria poesia.

É como se o Mestre aceitasse uma classificação dos juízos estéticos como subjetivos em busca de uma concordância a posteriori. E Ivan concorda e a fala é repentina, caracterizada pelo narrador como tendo sido feita com coragem e francamente (abertamente, откровенно). Seria a primeira vez que Ivan é capaz de autoavaliar esteticamente sua própria produção? Autoavaliar é uma espécie de autocompreensão e leva à (auto)consciência, mas a uma consciência entendida segundo outros critérios do que os do realismo socialista. Alguém capaz de se autocriticar é alguém que se idealiza menos, que se conhece melhor pelo que é do que alguém que se vê através dos óculos do que gostaria de ser.

É alguém que tem coragem de ser franco e perceber suas próprias fragilidades. É por isto que uma formação de um sujeito capaz de se (auto)criticar passa necessariamente pela necessidade de falar com coragem e francamente. E, para reforçar a ideia de que talvez tenhamos encontrado nessas características de sua fala repentina nesse momento dois possíveis critérios para a organização do desenvolvimento da formação de Ivan, vale a pena ver como são exatamente essas as características principais da parresía para Foucault 13: "A parresía é, portanto, em duas palavras, a coragem da verdade naquele que fala e assume o risco de dizer, a despeito de tudo, toda a verdade que pensa” (FOUCAULT, 2011, p. 13). Embora não vá proceder ao aprofundamento de que a noção foucaultiana merece - por exemplo, na relação entre a tradição socrática e cínica, a qual poderia se relacionar com um problema parecido em Bakhtin -, cito Candiotto (2010) para dar o horizonte do problema que quero mobilizar com a parresía: "a liberdade corajosa de enunciação precisa estar vinculada ao dever ético de falar a verdade, desde que o dever proceda daquela coragem" (CANDIOTTO, 2010, p. 150). Em seguida, procede a uma citação que vale a pena reproduzir por dar conta do que estamos tentando pensar que esteja colocado na questão da formação em O Mestre e Margarida:

\footnotetext{
${ }^{13}$ Quem primeiro aproximou Bulgákov de Foucault foi Weir, mas apenas do Foucault de As palavras e as coisas e de A prosa do mundo. Aqui vemos potencial para uma aproximação com o Foucault dos últimos cursos e vamos desenvolver essa ideia ao longo desta dissertação.
} 
A parrhesía é uma espécie de atividade verbal pela qual o falante tem uma relação específica com a verdade por meio da franqueza, uma certa relação com a própria vida por meio do perigo, um certo modo de relação consigo ou com os outros por meio de uma crítica (autocrítica ou crítica a outrem) e uma relação específica com a lei moral por meio da liberdade e do dever. Mais precisamente, a parrhesía é uma atividade verbal pela qual um falante exprime sua relação pessoal à verdade e arrisca a própria vida porque reconhece que 'dizer a verdade' é um dever que ajuda outras pessoas (bem como a si próprio) a viver melhor. (CANDIOTTO, 2010, p. 151).

Por conta da presença do diabo em Moscou - esse gênio maligno das questões e do conhecimento -, Ivan não se forma então segundo o modelo de consciência da burocracia soviética oficial personalizado por Berlioz, mas por um modelo autocrítico em que poderíamos ver ecoar, a partir de Foucault, algo de parresiástico.

Ou seja, se pensarmos que a formação de Ivan segue o modelo realista socialista da dialética espontaneidade-consciência, ela acaba se revelando uma paródia desse modelo ao levá-lo a se questionar sobre os critérios que embasam essa mesma dialética. Isso ocorre no momento em que o Mestre procura mostrar a Ivan, com uma fala franca, que este havia se encontrado com Satanás. Até então, Ivan havia experienciado a presença do demônio como a quebra da visão dogmática anterior, mas ainda não havia sido capaz de desenvolver uma explicação discursiva para o que estava acontecendo. É nesse diálogo que o Mestre irá conduzilo a uma elaboração racional dos últimos acontecimentos pelos quais passou e, aos poucos, Ivan começa a fazer ponderações que o vão levando a formar uma nova visão de mundo a partir de critérios oriundos do personagem Mestre, e não mais de Berlioz. Esse processo tem algo de cômico - comicidade, aliás, que não encontramos em Foucault - e ressalto aqui apenas a parte em que Ivan utiliza expressões idiomáticas de quem está ativamente seguindo um raciocínio de um outro e, com isso, se formando, o que significa tornar-se consciente:

Ivan bateu com força na sua própria testa com a palma da mão, e disse com voz roufenha:

- Compreendo, compreendo. No seu cartão de visita havia a letra 'W'.

'Mas que coisa!' Durante algum tempo, Ivan, totalmente perturbado, ficou em silêncio, escrutando com o olhar a lua que flutuava do lado de lá da grade. Depois disse:

- .Portanto, ele poderia realmente ter estado com Pôncio Pilatos? Já era nascido então. E ainda me chamam de louco! - acrescentou Ivan, apontando com indignação a porta. (BULGÁKOV, 1992, p. 150) (itálico nosso). 
Até este momento, Ivan ainda não está formado. Ele age com boas intenções, mas espontaneamente e de modo descoordenado, com o intuito de fazer coisas boas e remediar o mal que a visita de Woland poderia causar à sua cidade. Não à toa que ele termina sua formação em um sanatório, onde ainda é possível ver a realidade segundo seus próprios critérios de verdade, na medida em que eles estão deslegitimados como estando fora do padrão do que é o normal. A diferença entre os dois tipos de formação, a informativa e a crítica, - e o próprio fato de o Mestre estar em um sanatório - evocam as características do gênero da menipeia levantadas por Bakhtin da "representação de estados psicológicos-morais anormais do homem", e da menipeia como um gênero de contrastes, em que o personagem Mestre está em um sanatório e em que Ivan será formado justamente por ele:

Na menipeia aparece pela primeira vez também aquilo a que podemos chamar experimentação moral e psicológica, ou seja, a representação de inusitados estados psicológicos-morais anormais do homem - toda espécie de loucura ('temática maníaca'), da dupla personalidade, do devaneio incontido, de sonhos extraordinários, de paixões limítrofes com a loucura. [...] A menipeia é plena de contrastes agudos e jogos de oximoros: a hetera virtuosa, a autêntica liberdade do sábio e sua posição de escravo, o imperador convertido em escravo, a decadência moral e a purificação, o luxo e a miséria, o bandido nobre, etc. (BAKHTIN, 2013, p. 133-4).

Sendo a sátira menipeia um gênero de crítica de ideologias e de concepções préformadas, a paródia da estrutura do realismo socialista em $O$ Mestre e Margarida pode significar uma busca por desestabilizar as concepções estético-políticas da cultura soviética oficial dos anos 1930. Ao parodiar o tipo de formação do realismo socialista, a obra "questiona, numa dinâmica dialética, não só o modelo artístico sobre o qual é criada, como também o discurso ideológico e as componentes do acervo cultural da época de sua criação" (ANDRADE, 2010b, p. 258).

$* *$

Um outro aspecto da sátira menipeia presente em $O$ Mestre e Margarida é a fantasia. Para entender a sua presença no romance, é preciso perceber que ela surge da relação de Bulgákov com a tradição do realismo russo, tal como aponta Andrade:

A sátira bulgakoviana, como já se viu, tem suas raízes cravadas no realismo russo do século XIX. Não se trata, é claro, de simples imitação dos modelos tornados clássicos por Gógol, Saltykov-Schedrin, Dostoiévski, Tchékhov. 
Tampouco se trata de uma ruptura desses modelos, mas, como se verá nos subcapítulos seguintes, de uma continuidade deles, onde o velho permeia o novo, renova seu significado, adquire uma função diferente daquela original. (ANDRADE, 2010b, p. 254).

Se o realismo socialista é também uma crítica ao simbolismo e às vanguardas, as "raízes cravadas no realismo russo do século XIX” em Bulgákov apontam uma outra saída metodológica: elas indicam que a sátira de Bulgákov estava engajada em representar a realidade de seu tempo, mas que para isso era preciso renovar os métodos dessa representação, pois a nova realidade o demandava. Ter como base o realismo "crítico" do século XIX poderia ser visto como uma espécie de conservadorismo artístico, tal como afirma Andrade no mesmo estudo:

O intelligéntni (da intelligentsia) Bulgákov não pertencia a qualquer front e considerava o experimentalismo poético do front esquerdo tão artificial quanto o homo soviéticus em construção. Sua obra, impregnada da crença nos "belos princípios da vida", renovava a herança literária do passado e era ignorada pelos teóricos. Bulgákov interessava-se por questões filosóficas e preocupava-se com o destino de seu herói (o homem sem importância) na nova ordem. $\mathrm{O}$ dividido (entre duas épocas) Bulgákov encarava com pessimismo as transformações sociais decorrentes do regime. (ANDRADE, 2010b, p. 250).

Essa base no realismo "crítico" de Bulgákov - sua inserção no movimento da literatura fakta como uma resposta ao simbolismo russo e sua "tendência à idealização 'romântica' dos fatos sociais e históricos, bem como de seus heróis (anônimos ou não), ao abordar os acontecimentos da Revolução e da guerra-civil” (ANDRADE, 2010b, p. 253) - entra em conflito com a novidade da compreensão da relação entre realidade e arte: retratar a realidade de uma época em que a realidade é entendida como criada é contraditoriamente criar a realidade retratada. É o que afirma Clark, sobre o método de representação realista socialista nos anos 1930:

\begin{abstract}
Although these leaps were officially grounded in theory, once the leaper took to the air he was already in the realm of the fantastic. The thrust up from prosaic reality to somewhere "higher" became a key image of political culture in the thirties. All those paragons of the new master race, the symbolic heroes, were said to make such a leap, figurative or actual, and thus go "higher". (CLARK, 2000, p. 137) ${ }^{14}$.
\end{abstract}

\footnotetext{
14 “Embora esses saltos fossem fundados oficialmente na teoria, uma vez dado o salto, já se estava no reino do fantástico. A passagem da realidade prosaica para algo 'mais alto' se tornou a imagem chave da cultura política nos anos 1930. Sobre todos esses paradigmas da nova raça de mestres, os heróis simbólicos, afirmou-se que davam um salto deste tipo, figurativo ou atual, e que ficavam 'mais altos'.” (Tradução nossa).
} 
Ao "buscar inspiração em elementos dos velhos sistemas da herança literária, que interpretavam à luz das últimas novidades no domínio da estética literária" (ANDRADE, 2010b, p. 254), a prosa satírica de Bulgákov em O Mestre e Margarida leva essa relação entre velhos sistemas e novidades da estética literária ao limite, pois não compõe superficialmente sua obra com as obras da tradição (em geral russa, mas não só), conquanto as explora em suas contradições.

A posição do romance de Bulgákov é extremamente complexa, pois também é preciso levar em conta o que Weir sugere, a saber, que o romance está mais próximo de seu tempo - a sátira dos anos 1920 e o simbolismo - do que fazem parecer as muitas tentativas de que ele seja o elo que reconecta o realismo pré-revolucionário aos tempos pós-soviéticos:

From a late-twentieth-century perspective it is easy to see The Master and Margarita as a link between high modernism of the teens and twenties-preSovietized Russian literature-and the myriad postmodernisms of the eighties and nineties that lie in its distant wake. But the novel seems to regard its own position differently, as one caught between the contradictory aesthetic goals of romanticism and nineteenth-century realism, on the one side, and symbolism and 1920s satire, on the other. ${ }^{15}$ (WEIR, 2002, p. 24).

Se Meletínski via que Dostoiévski, ao continuar exatamente de onde Gógol parou, se afasta deste justamente na medida em que aprofunda psicologicamente o universo arquetípico de Gógol, e “desse modo, supera-se o conhecido 'marionetismo' dos tipos gogolianos, que coincidem com suas próprias “máscaras"” (MELETINSKI, 2002, p. 210), Bulgákov segue outra via de continuação de Gógol ${ }^{16}$, a qual, no entanto, acaba tendo o efeito semelhante ao de Dostoiévski de alargar o rol de atuação dos arquétipos de caos e cosmos e ao mesmo tempo, de modo paradoxal, de renová-los. Ao invés de interiorizar na subjetividade dos personagens a dialética entre caos e cosmos, o que não seria possível nem em uma realidade em que a fala franca e a discussão estão inviabilizadas mesmo em ambiente privado, nem na paródia, Bulgákov aplica-se no aprofundamento e exacerbação do método satírico gogoliano,

\footnotetext{
15 "De uma perspectiva do fim do século XX, é fácil ver $O$ Mestre e Margarida como um elo entre o alto modernismo dos anos de 1910-20 - literatura russa pré-soviética - e a miríade de pós-modernismos dos anos 1980 e 1990 de um despertar distante. Mas o romance parece encarar de modo diferente sua própria posição como tendo sido pego entre os objetivos estéticos contraditórios do romantismo e do realismo do século XIX, por um lado, e do simbolismo e da sátira dos anos 1920, por outro.” (Tradução nossa).

16 "Oferecendo uma análise literária da realidade russa num momento de reviravolta sócio-histórica aguda, Dostoiévski sintetizava nos limites essa análise, ampliando-a até as dimensões cósmicas do mundo, que de modo paradoxal levou ao renascimento dos velhos arquétipos com sua envergadura mitológico-cósmica e, ao mesmo tempo, ao seu extraordinário aprofundamento e generalização." (MELETINSKI, 2002, p. 280).
} 
parodiando a própria sátira gogoliana. São muito pertinentes quanto a isso as considerações de Andrade sobre o personagem-autor de "As aventuras de Tchítchikov":

\begin{abstract}
Para montar em seu poema a caricatura paródica do herói narrador-autor que é simultaneamente uma máscara verbal e literária de Gógol, Bulgákov sobrepõe uma série de imagens especulares que ora deformam ou conformam, ampliam ou reduzem, aproximam ou afastam, repetem ou invertem o objeto refletido. Como sonhador, ele é autor do sonho. Por sua vez, o sonho é paródia de uma determinada realidade que se presta como modelo para uma paródia da sátira de Gógol. Como autor do sonho, ele é autor da paródia e também seu narrador. Como narrador, autor de uma paródia satírica. Como autor, é o ator de si próprio que, antes de vender o livro, se alegrava com a leitura de Gógol nas noites sombrias de insônia e, agora, dormindo, sonha com ele. Como ator, deus ex machina que estabelece a ordem na paródia satírica. Como diabo, Gógol. Como Gógol, é Bulgákov. Como Bulgákov é o Gógol de sua época, e portanto, "que embaixo de cada olho desse filho do diabo cresça um calombo do tamanho de um bonde!" [...]. (ANDRADE, 2010b, p. 273).
\end{abstract}

Nessa paródia da sátira, encontramos um aprofundamento crítico em relação aos próprios polos que compõem a dialética entre caos e cosmos, entre mal e bem, entre espontaneidade e consciência, entre desordem e ordem etc. - polos que cumprem suas funções de polos na dualidade da dialética, mas que não se equivalem, fazendo com que a relação entre o conteúdo dessas dialéticas seja difícil: esses polos ou máscaras são, ao mesmo tempo, aniquilados e renovados no exercício crítico da sátira e da paródia.

O próprio texto-paródia “As aventuras de Tchítchikov” (BULGÁKOV, 2010) pode ser tratado como um exemplo desse aprofundamento de Gógol diferente do de Dostoiévski. Em um sonho extravagante, Tchítchikov, herói do romance Almas mortas de Gógol, vai parar na realidade "atual” de Bulgákov, após um "diabinho gozador" abrir as portas "à entrada do reino das trevas sobre a qual tremeluzia uma lâmpada perpétua com a inscrição "Almas mortas" (BULGÁKOV, 2010, p. 15). Se quem abre a porta é o diabinho gozador, que podemos ver como personalização poética do satírico - o que dá a chave de como o retorno de Tchítchikov ao espaço da Rus (agora adjetivada soviética) deve ser compreendido -, podemos ver o reino das trevas, o reino dos mortos, em sua multivocidade como uma espécie de baú mágico no qual se guardam os tipos sociais, como bonecos prontos a serem utilizados em outras histórias, e toda sorte de coisas de antigas "apresentações". A inscrição "Almas mortas", como a etiqueta em uma proveta química, diz a quem abrir aquele baú que tipo de substância encontrará ali - e não apenas substância em formato de personagem, pois como pontua Andrade, tanto a própria forma do texto-paródia quanto o discurso do narrador são tomados parodicamente do poema 
gogoliano ${ }^{17}$ : até mesmo a alusão ao reino dos mortos (ao invés, por exemplo, da imagem do baú mágico aqui sugerida) é, claro, já uma referência gozadora que joga com a multivocidade - que Gógol já utilizava - da expressão "almas mortas”. Ao abrir o baú, o reino dos mortos, o escritor tem de lidar com o diapasão entre texto parodiado e texto-paródia nos mais diferentes aspectos.

Assim, enquanto o "sonho extravagante" resolve alguns problemas da prosa, em $O$ Mestre e Margarida essas soluções serão igualmente satirizadas, sem solucionar nada: a história de Jesus vai sendo intercalada no decorrer do romance ora saindo da boca de Woland, ora em sonho de Ivan, ora ainda será encontrada escatologicamente por Bieguémot; no limite, será o slogan-paródia "os manuscritos não queimam” a solução satírica para esse problema, e não o sonho (embora o epílogo utilize uma solução parecida com a do sonho de "As aventuras...": Ivan, agora professor universitário de história, volta ao banco da praça do Patriarca todos os anos no plenilúnio festivo da primavera e conversa francamente consigo, depois vai para casa e sonha com a história de Jeshua). Em contrapartida, também o narrador deus ex machina que Andrade analisa na citação acima deixa de ficar aparente em $O$ Mestre e Margarida, embora seus recursos estejam distribuídos ao longo das várias situações do romance. Se bem que o narrador do romance esteja em terceira pessoa e se assemelhe com o narrador de Almas mortas de Gógol ao fazer comentários em primeira pessoa de modo inadvertido - ao contrário do narrador de As aventuras de Tchítchikov, o qual não faz longas digressões sobre a Rússia ${ }^{18}$-, a função de deus ex machina, por exemplo, é dada a Woland e sua trupe. Além dos nomes com que o narrador vai chamando seus personagens - Woland, no primeiro capítulo, é chamado (fausticamente, é claro) de estrangeiro, desconhecido, professor e estudioso -, evidenciando que o narrador compartilha da subjetividade de seus personagens, em outras passagens - e talvez de modo mais evidente na que vem a seguir - temos um dos muitos exemplos em que o narrador toma posição indo além de sua função de narrador onisciente em terceira pessoa:

\footnotetext{
17 (ANDRADE, 2010b, p. 259): “Em 'As aventuras de Tchítchikov' (1922), Bulgákov toma como modelo Almas Mortas de Gógol. Por trás da linguagem direta e simples do texto, que lembra o feuilleton dos jornais da época, por trás de uma aparente falta de acabamento literário, disfarçam-se relações extremamente complexas, intra e extratextuais. A começar do título escolhido por Bulgákov, que é o primeiro título da obra de Gógol. Brincando com Púchkin que classificara o poema Evguéni Oniéguin como romance, Gógol resolveu chamar sua obra satírica em prosa de poema, talvez para reforçar sua dimensão épica. Bulgákov faz o mesmo. Gógol dividiu Almas Mortas em capítulos. Bulgákov divide 'As aventuras de Tchítchikov' em 'dez pontos com prólogo e epílogo'. Cada 'ponto' deve ser entendido como um momento especial do desenvolvimento de algo. Em dez pontos Bulgákov capta momentos especiais do texto-modelo e, com eles, constrói sua paródia. Esses momentos sempre se referem à ação do enredo de Almas Mortas". E (p. 265): "Outras vezes, é parodiado o discurso do narrador gogoliano".

18 (ANDRADE, 2010b, p. 259-60): "Não são diretamente parodiadas as longas digressões de Gógol sobre a Rússia e seus comentários sobre o caráter das personagens, uma vez que esse tipo de procedimento não caberia na estrutura de um sonho".
} 
Não sabemos que outras coisas extraordinárias aconteceram naquela noite em Moscou, e é claro que não faremos tentativas de descobrir, mesmo porque já é hora de passar à segunda parte desta história verídica. Siga-me, leitor! (BULGÁKOV, 1992, p. 237).

E, em seguida, no início da Segunda Parte:

Siga-me, leitor! Quem lhe disse que não existe neste mundo o amor verdadeiro, fiel e eterno? Que cortem a esse mentiroso a sua língua suja!

Siga-me, leitor, siga só a mim e vou mostrar-lhe tal amor!

Não! O Mestre estava enganado quando disse amargamente a Ivan, no hospital, já passando da meia-noite, que ela o esquecera. Isso não aconteceu. Ela não o tinha esquecido.

Em primeiro lugar, vamos revelar o segredo que o Mestre não quis revelar a Ivan. [...] (BULGÁKOV, 1992, p. 237).

E em Gógol:

Feliz o escritor que, passando ao largo das personagens enfadonhas, repugnantes, que nos repelem com o seu triste realismo, aproxima-se das personagens que mostram a elevada dignidade humana; o escritor que, no grande torvelinho das imagens cotidianas, soube escolher apenas as poucas exceções, que não modificou jamais a elevada afinação da sua lira, jamais desceu dos seus altos cumes até os seus irmãos humildes e apagados, e, sem tocar a terra, mergulhou inteiro nas suas imagens tão distantes dela e tão exaltadas. [...] (GÓGOL, 2008, p. 171).

Além disso, outro elemento importante da atuação do narrador são os títulos satíricos dos capítulos que evidenciam o caráter ficcional do texto, expondo contraditoriamente uma quebra na verossimilhança, visando um efeito cômico. Desse modo, ao parodiar a prática satírica de Gógol, Bulgákov provê de interpretação a tradição literária russa; ao ser o Gógol de sua época, exige que não vejamos a história do desenvolvimento literário como uma evolução contínua em que cada escritor surge negando o anterior. Não há harmonia entre base metodológica de representação realista e "estilização estética" em O Mestre e Margarida, mas conflito. A representação realista dos "velhos sistemas da herança literária" não cumpre sua função de verdade nesta nova realidade. O método está desencontrado de seu conteúdo ${ }^{19}$. E é

\footnotetext{
${ }^{19}$ Quanto ao embate aludido de procedimentos literários ou artísticos, nunca é demais indicar que havia, de fato, diversos embates desse tipo no interior dos debates teóricos sobre arte, ciência, literatura etc. nos anos que se seguiram à revolução. Um deles, análogo ao aqui mobilizado, é o que se deu no interior do VChUTEMAS em torno de noções como "composição" e "construção". Sobre isso, ver (MISLER, 2012, p. 384): "In effeti sin dall'inizio del 1921 si era già creata una fratura anche all'interno di questo gruppo d'avanguardia, fra architetti $<<$ razionalisti $\gg$ (Nikolaj Ladovskij, Nikolaj Dokučaev e altri) e teorici costruttivisti (Rodčenko, Konstantin
} 
deste conflito, deste desencontro, que surge o fantástico e a ficção científica satíricos - esta última não presente em $O$ Mestre e Margarida, mas em outros textos importantes de Bulgákov -, a fim de que o método possa ser atualizado e se adequar à verdade da nova realidade. Desse modo, se podemos dizer que Bulgákov, além de "ter retomado e atualizado os procedimentos típicos do assim chamado realismo crítico da tradição literária do século XIX, criou um novo gênero: a ficção científica satírica" (ANDRADE, 2010b, p. 251-2), podemos dizer também que isso não se deu de modo pacífico, harmônico, superficial, uma mera brincadeira formal, uma volta ao passado, alienação ou como uma estilização bulgakoviana, mas sim por o autor ter levado às últimas consequências, consciente e criticamente, suas influências de métodos representacionais da realidade, bem como a singularidade da verdade da realidade de sua época em sua própria prosa.

Poder compreender essa retomada e atualização como o comprometimento consciente com esse conflito de Bulgákov pode nos mostrar como tal conflito, ao mesmo tempo, assume caráter literário e extraliterário. Se o novo gênero criado por Bulgákov responde aos problemas da evolução do método literário no interior da prosa russa, não podemos afirmar também que o fantástico satírico - bem como a "ficção científica satírica", aqui não tratada - pode cumprir uma função de atentar, não contra o gosto burguês, mas sim contra o gosto soviético oficial?

“Isto não pode ser!...” (BULGÁKOV, 1992, p. 12) pensa, perturbado, o crítico - Berlioz - ao ter uma visão extraordinária de um "homem transparente, de aspecto muito esquisito", em cuja fisionomia "desenhava-se o escárnio", após tomar o seu pileque. Mas, afirma o narrador onisciente, aquele homem, "infelizmente, existia". Existia de que maneira? podemos nos perguntar. Que tipo de existência pode ter a ficção dentro da ficção? E quem é esse narrador onisciente que afirma tal existência de modo tão categórico? Sabemos pelo desenvolver do livro

Medunecskij, Aleksej Gan, ecc.) sull'interpretazione del significato di $<<$ composizione $>>$ e $<<$ costruzione $>>$ ". "Com efeito, desde o início de 1921 já havia sido criada uma fratura no interior desse grupo de vanguarda entre arquitetos 'racionalistas' (Nicolai Ladovski, Nicolai Docutchaev e outros) e teóricos construtivistas (Rodtchenco, Constantin Medunecski, Aleksei Gan etc.) sobre a interpretação do significado de 'composição' e 'construção'." (Tradução nossa). Com essa aproximação, queremos mostrar como não se trata de mera arbitrariedade de nossa interpretação perceber essa contradição de método literário que se situa no próprio âmago da forma (difícil) literária de Bulgákov, mas surge como uma questão presente e proeminente da época de Bulgákov que, no seu caso particular, acaba tomando a forma particular que aqui estamos analisando. No caso do romance, esse embate assume corpo no interior mesmo do realismo socialista: uma espécie de composição do real que o constrói. Nossa posição é que Bulgákov é capaz de perceber essa contradição no interior da forma literária oficial soviética e explorá-la de forma satírica, a fim de promover reflexões de caráter ético no leitor. 
que tal narrador tem razão - de alguma forma, na ficção de Bulgákov, a fantasia realmente existe. E quem são, afinal, os desconhecidos estrangeiros que pululam nessa realidade pacata inautêntica dos cidadãos soviéticos?

Antes de tentar responder a estas questões, cabe-nos perguntar o que pode ser, na visão do perturbado crítico. Para isso, precisamos discutir o teor da conversa que ele trava com o jovem poeta. Ela versa justamente sobre a afirmação, em uma poesia - provavelmente por ocasião da semana santa -, da possibilidade e necessidade da existência ou não de Jesus Cristo. Com sua voz de tenor, ele desenvolvia sua argumentação erudita - "[penetrando] labirintos onde apenas uma pessoa muito erudita se arriscaria sem correr o risco de quebrar o pescoço" (BULGÁKOV, 1992, p. 16) - no sentido de negar a existência real de Jesus Cristo enquanto pessoa, não apenas enquanto o símbolo encarnado do poder extra-humano. Ele seria apenas mais um personagem ficcional criado por essa religião chamada cristã, uma entre tantas outras que poderiam ser chamadas de Offenbarungsreligion, mas que teria sua proeminência por ter sido por tanto tempo acreditada no mundo ocidental.

É precisamente no momento em que compara o mito de Jesus com o de outras religiões, como a asteca, que aparece a "primeira pessoa humana" na alameda. Essa pessoa humana é o estrangeiro desconhecido com quem não deveríamos conversar e que é tão difícil de ser descrito: cada um o experiencia à sua maneira. Ele é múltiplo, assumindo um aspecto diferente para cada olhar diferente.

Essa "pessoa humana" é a ficção em carne e osso. Por um lado, ela encerra em si mesma, em sua própria existência material, o próprio projeto mitológico de um Jesus inexistente sobre quem Berlioz discorre - e, portanto, é uma refutação "viva" da teoria do crítico soviético no nível de "realidade" dos personagens do romance. Por outro, ela só pode adentrar concretamente a realidade porque o crítico coloca em dúvida a própria realidade do real ao afirmar a irrealidade do que existe, ou seja, a inexistência de uma pessoa humana como Jesus Cristo foi, de modo independente do que num momento posterior tenha sido mítica e literariamente construído sobre ele pela tradição.

Em outras palavras, a maior justificativa formal para a sua aparição material na "realidade" de Berlioz é que essa "realidade" de Berlioz é, como ele mesmo estava até então defendendo, "construída" ou "criada". Ou melhor, poderíamos dizer que isso acontece porque, em seu discurso positivo sobre a realidade, está compondo uma nova história da tradição ocidental cristã; e, por conseguinte, ao reescrever a história, está perigosamente flertando com a ficção nesse terreno de "fatos", "verdades" e "positividade" que é a história, e, ainda mais, 
querendo que estes fossem trabalhados no discurso poético de Biezdomni - ou seja, fazendo ainda uma perigosa relação entre arte e verdade, entre ficção e história. Trata-se de uma ingenuidade, incongruência ou insuficiência de sua compreensão teórica da história e da literatura que abre espaço para o "questionamento cético", o qual ocorre como a efetivação do fantástico e da literatura na realidade - e é altamente estranho e instigante que o fazer cético, ao contrário da compreensão superficial que normalmente temos deste, tenha algo que ver com tornar real o extraordinário.

Podemos tentar entender isso por duas vias. Uma delas é a partir das especificidades da literatura oficial da década de 1930 soviética que Bulgákov parodia. Nela, houve um desenvolvimento maior de símbolos convencionais na literatura oficial que tornava cinzenta a fronteira entre textos ficcionais e não ficcionais. Isso é particularmente claro nas biografias, algumas das quais foram chamadas de romance. Clark afirma que:

In the thirties the distinction between fiction and nonfiction, between a factual biography and a fictionalized one, became fainter than ever before. One did not just find, as in earlier Bolshevik biographical writing (such as Furmanov's Chapaev), a definite ordering and selection of the real-life material to fit the patterns of Marxist-Leninist historiograph. All biographies were now standardized so that every subject's life, in both fiction and nonfiction, fit mythicized patterns. A case in point would be Vs. Ivanov's Parkhomenko (1938-39), an account of the Civil War commander of that name. This work was called a novel, and it was published elsewhere as biography. Whether classified as fiction or non fiction, all biographies were now fantastic: the Gleb Chumalovs of fiction now dominated nonfiction, too. (CLARK, 2000, p. $123)^{20}$.

\footnotetext{
20 "Nos anos 1930 a distinção entre ficção e não ficção, entre biografia fatual e ficcionalizada, se tornou mais fraca do que nunca. Não se encontra, como na escrita biográfica bolchevique anterior (como Chapaev de Furmanov), uma ordenação e seleção definida do material da vida real adequando-se aos padrões da historiografia marxistaleninista. Todas as biografias agora eram estandardizadas de tal modo que todo o conteúdo da vida, tanto na ficção quanto na não ficção, se adequava a padrões mitologizados. Um caso deste tipo seria Parkhomenko (1938-39) de Vs. Ivanov, um relato do comandante da Guerra Civil que tinha esse nome. Chamaram esta obra de romance e foi publicada alhures como biografia. Classificadas como ficção ou não ficção, todas as biografias eram agora fantásticas: os Gleb Chumalovs da ficção agora dominavam também a não ficção." (Tradução nossa). Quanto a isso, vale a pena citar a seguinte passagem de Andrade: "A partir daí consagrou-se uma primeira definição geral de realismo socialista, devidamente inserida no universo do pensamento marxista-leninista. O novo método, também conhecido pela sigla 'sotsrealizm' (sotsialistítcheski realizm), devia representar a realidade conjunta, presente e passada, à luz da luta pelo socialismo, e sua característica distintiva devia ser uma mentalidade proletária de partido. Acontece que na ditadura do proletariado era o Partido quem estabelecia totalitariamente as prioridades da 'luta pelo socialismo' e forjava a 'mentalidade proletária'; portanto, a realidade soviética refletida pelo realismo socialista era deturpada em virtude da propaganda, das táticas e estratégias empregadas para a obtenção dos objetivos estabelecidos. Aliás, o falseamento da própria realidade e dos fatos históricos estavam na ordem do dia, servindo ao culto da personalidade de Stalin, fortalecendo o regime e o Partido. Assim, grosso modo, a realidade em vigor era a decretada pelo Partido e ai de quem ousasse enxergar a realidade de fato. O processo de endeusamento do todo-poderoso pai de todos os proletários do mundo, do deus-vivo, erigia a igreja do stalinismo, guiava corações e mentes, criava mecanismos inquisitoriais de controle da realidade presente, passada e futura, instituindo uma versão atualizada dos tribunais do Santo Ofício. Esse culto à personalidade adquiriu proporções
} 
Se Clark está analisando as biografias de pessoas que viviam em 1930, pode-se dizer que o que Bulgákov faz é aplicar esse modelo de biografia à biografia de Jesus Cristo: o poema sobre Jesus Cristo de Biezdomni transita nessa zona cinzenta em que biografia se torna ficção, em que a realidade é transposta em convenção, símbolo, ícone. Berlioz não apenas professa uma palestra do tipo dialogal mestre-aprendiz. Ele também está determinando o que pode e o que não pode ser realidade, ele está determinando os critérios de verdade do discurso, e os critérios são não a realidade mesma, mas o seu próprio discurso enquanto o discurso de alguém inserido no organismo cultural oficial. Esta aplicação tem de ser vista como um ato paródico de ridicularização e afastamento em relação a esse mesmo procedimento da cultura oficial.

Ao mesmo tempo, esse procedimento de embaralhar realidade e ficção é também satirizado com a entrada inesperada de Woland, entrada que promove uma quebra no tipo de diálogo mestre-aprendiz e, com isso, também um distanciamento crítico em relação à mistura entre realidade e ficção e à determinação oficial dos critérios de verdade. Talvez a função da ficção Woland aqui seja a mesma do gênio maligno de Descartes: se uma ficção é capaz de abalar minhas certezas, então é porque essas certezas não estão suficientemente fundamentadas. Ou ainda, em caráter ao mesmo tempo mais amplo e mais restrito, Woland - e, por que não, também o gênio maligno cartesiano - surge a fim de provocar uma ideia filosófica, o que é uma das características mais importantes do gênero da menipeia para Bakhtin:

A particularidade mais importante do gênero da menipeia consiste em que a fantasia mais audaciosa e descomedida e a aventura são interiormente motivadas, justificadas e focalizadas aqui pelo fim puramente filosóficoideológico, qual seja, o de criar situações extraordinárias para provocar e experimentar uma ideia filosófica: uma palavra, uma verdade materializada na imagem do sábio que procura essa verdade. Cabe salientar que, aqui, a fantasia não serve à materialização positiva da verdade, mas à busca, à provocação e principalmente à experimentação dessa verdade. (BAKHTIN, 2013, p. 130).

Mais amplo, porque insere a prosa de Bulgákov em um gênero literário com raízes na antiguidade; mais restrito, porque essas considerações foram escritas e pensadas no mesmo contexto social e cultural no qual Bulgákov desenvolveu sua prosa. Bulgákov se aproxima do gênero da sátira menipeia tal como pensado por Bakhtin: algo particular, mas que ao mesmo tempo o coloca dentro de uma longa linhagem de desenvolvimento histórico literário. De

mitológicas e fixou-se como o traço distintivo da sociedade soviética nas décadas de 1930-1940, exercendo sua influência nefasta também na literatura e nas artes" (ANDRADE, 2010a, p. 161). 
qualquer modo, se for verdade que Woland quebra o tipo de diálogo mestre-aprendiz, provendo um distanciamento crítico em relação à doutrinação, com o que a provoca filosoficamente, também pode ser verdade que, ao menos em certo aspecto, a escolha por Jesus Cristo, caso tenha sido arbitrária, tem, no mínimo, a função de afrontar o gosto soviético. Ou seja, ela dá particularidade - as décadas de 1920 e 1930 soviéticas - à efetivação do gênero (sátira menipeia) operada por Bulgákov ao criar uma situação provocativa em relação ao poder oficial $^{21}$.

Já em uma segunda via, seria compreender a aparição de Woland a partir do paradigma do fáustico. Se as noções de história e ficção são constituintes de qualquer tentativa de definição e compreensão do que é próprio do ser humano, esse visitante desconhecido, mestre em magia negra, é talvez aquele que mais profundamente entre em contato com as profundezas do humano nos mais recônditos lugares e nos mais variados tempos - mesmo que não as tenha entendido por completo. O visitante que acompanha Fausto da porta da cidade até seu escritório, na figura de um cachorro negro, talvez não seja tão inesperado para o erudito germânico, mas o êxito de seu empreendimento naquele contex to depende do mesmo que na sua passagem soviética - ser, ou ao menos se achar, capaz de compreender intimamente o humano.

Tal personagem aparece em Moscou contraditoriamente como um elemento humanizante, na medida em que é evidentemente ficcionalizante e pleno de contradições. Mas essa contradição de sua aparição não se limita a isto: ela é também o fantástico que dá o teor de verdade dessa "espécie de "neorrealismo"” (ANDRADE, 2010b, p. 254); Woland interrompe o diálogo mestre-aprendiz e com isso instaura não o fim da formação, mas o começo da crítica (paródica) desta formação; nega (a realidade, a formação etc.) afirmando, afirma (o mau, a existência do fantástico) negando, fazendo jus à epígrafe do romance.

Em Bulgákov, a combinação de fantástico e realismo leva a uma abertura a questões filosóficas, sejam elas éticas, morais ou metafísicas ${ }^{22}$. A negação crítica e a paródia da fala do

\footnotetext{
${ }^{21}$ Embora o romance soviético devesse ser "A sort of eclectic summa of all great literature, [...] the only kinds of writing to be specifically excluded were so-called formalist writing (e.g., parody, experimentalism, and varieties born of literary self-consciousness), decadent or erotic writing, 'pessimistic' literature, and writing colored by the values of rival world systems, such as Christianity" (CLARK, 2000, p. 36). "Uma espécie de summa eclética de toda a grande literatura, [...] os únicos tipos de escrita especificamente excluídos eram a assim chamada escrita formalista (como paródia, experimentalismo, e variedades nascidas da autoconsciência literária), a escrita decadente ou erótica, a literatura 'pessimista' e a escrita tingida por valores de sistemas-mundo rivais, como o cristianismo." (Tradução nossa).

${ }^{22}$ Andrade, ao analisar essa abertura ao filosófico nas novelas Os ovos fatais e Um coração de cachorro, afirma: "Em ambas as novelas [Os ovos fatais e Um coração de cachorro, mas podemos dizer que também em $O$ Mestre e Margarida], ele [Bulgákov] combina o realismo e o fantástico decorrente dos experimentos científicos, acrescentando às imagens e situações um sentido filosófico. [...] Desse modo, o confronto dos pro e contra a respeito das posições filosóficas suscitadas por questões éticas e morais da época, assim como a discussão dos
} 
'mestre' Berlioz, tanto em seu conteúdo como em seus parâmetros de verdade, transformam a formação de Biezdomni de modo inexorável: "nunca fale com pessoas desconhecidas" pode significar, então, como vemos a seguir, que a formação plural e de múltiplas vozes constitui uma formação crítica, ao ruirem as narrativas com questões como: “- Mas permita-me perguntar - voltou a falar o visitante estrangeiro, após uma reflexão inquietante - o que vamos fazer com as provas da existência de Deus, cujo número, como é sabido, é igual a cinco?" (BULGÁKOV, 1992, p. 18).

Ao longo desse processo de crítica da (in)formação, podemos ver que a primeira reação de Ivan é a de se agarrar à visão de mundo inicial, sem vontade de se abrir à experiência negativa, revelando, com isso, um dos pilares da ordem do discurso oficial de Berlioz: “- Deverse-ia agarrar esse tal de Kant e metê-lo em Solovki por uns três anos, por causa do tal argumento! - soltou inesperadamente Ivan Nicolaievitch” (BULGÁKOV, 1992, p. 18).

Desse modo, do ponto de vista da relação dialogal deste primeiro capítulo do romance, Woland impõe uma mudança no tipo de diálogo: como um professor que entra na sala de um outro (ou em um domínio narrativo e discursivo de um mestre), torna o aprendiz em plateia de uma aparente disputa filosófica. É claro que tudo ocorre de modo paródico, e não há, de fato, grandes discussões filosóficas sobre o que quer que seja. O que há é uma aparência satírica dessa discussão, dessa situação dialogal, o que é suficiente para expor a contraposição ou negação da estrutura narrativa e do critério de verdade do discurso professoral e informativo de Berlioz - discurso que, por sinal, também era mera caricatura satírica.

Os próprios critérios de verdade de Woland não são muito melhores do que a coerção do cidadão que discorda do discurso oficial a ficar preso em Solovki por três anos: seu café da manhã com Kant, o óleo de girassol que Annuchka comprou e derramou, ser especialista em magia negra...

Nesse sentido, Woland não nega, por um lado, seu arquétipo diabólico; por outro, assume, de certo modo, como o sobre-humano que é, um ar aristocrático de um emigrado místico (ou seja, daqueles membros da intelligentsia que deixaram a Rússia após 1917) que faz uma "visitinha" ao seu país de origem (como se isso fosse possível, e mais - satirizando com isso tanto a chegada de Lênin à Rússia, inúmeras vezes representada na literatura e cinema soviéticos, como o status deste antirrevolucionário de estar fora de seu lugar na normalidade da

problemas sociopolíticos contemporâneos, inserem novamente a sátira bulgakoviana no universo da sátira menipeia e, portanto, da literatura carnavalizada [...]. E o fantástico contribui para isso, não como a encarnação definitiva da verdade, mas criando situações excepcionais em que a verdade é submetida à prova" (ANDRADE, 2010b, p. 293-4). 
vida soviética). Isso se evidencia, entre outros momentos, no episódio (diabólico e fáustico) dos cigarros e suas diversas marcas ainda durante essa conversa entre Berlioz, Ivan e Woland, no ar místico do personagem, em sua propensão (paródica) à discussão pretensamente filosófica, e em sua premonição ou determinação mística de quando, onde e como se daria a morte de Berlioz.

Woland, ao romper com o âmbito do diálogo mestre-discípulo, cumpre seu papel de elemento fantástico no interior da prosa de Bulgákov, ao funcionar como elemento crítico das imperfeições seja sociais, seja do discurso oficial, levando à autorreflexão, como se fosse um verdadeiro daimon socrático:

Oriundo de um processo de hiperbolização próprio da sátira, ele [o fantástico] visa não só ao efeito cômico, mas presta-se como instrumento de revelação das imperfeições sociais e, paradoxalmente, como elemento de conscientização do leitor acerca dessas imperfeições (ANDRADE, 2010b, p. 288).

Em relação às estruturas dialogais do romance, a aparição de Woland faz o diálogo mestre-discípulo se transformar em uma disputa filosófica entre Berlioz e Woland, como já anteriormente mencionado. Mesmo que isso se dê de maneira satírica e superficial, a aparição da figura fáustica de Woland coloca em jogo, no conteúdo dos diálogos que compõem o romance, as precedências filosóficas dos problemas do método representacional que Bulgákov renova. Nisso, vemos como o tema mobilizado por Woland assume um caráter de época - as grandes questões da virada do século XIX para o XX: a desvalorização de todos os valores, a morte de deus, o sentido da vida.

Por meio do fantástico, chegar às "últimas questões" é ainda outra característica central do gênero da menipeia, como já vimos. Trata-se de lançar luz não apenas ao como da "sátira bulgakoviana [inserir-se] no universo da sátira menipeia" (ANDRADE, 2010b, p. 293), mas também ao porquê disso, por meio das considerações de Bakhtin, contemporâneo de Bulgákov. Teria Bulgákov lido ou se apropriado de alguma forma de Bakhtin, ou essas semelhanças se dariam mais propriamente por ambos compartilharem do mesmo ambiente cultural?

Malgrado a dificuldade de responder a essa questão, pode-se dizer que em $O$ Mestre $e$ Margarida o fantástico com função satírica põe em discussão um aspecto próprio ao humano: os procedimentos de constituição e verossimilhança das narrativas. Os temas da morte de deus, do sentido da vida, em suma, da condição humana, do embate de posições filosóficas (satirizadas) sobre o homem no diálogo entre Woland, Biezdomni e Berlioz carregam em seu 
bojo o problema do discurso, da narrativa, da verossimilhança, da verdade etc. Eles acabam levando o leitor a questionar as relações de poder e os critérios de verdade que estruturam os discursos e as relações entre linguagem e realidade:

- Eis, porém, a questão que me preocupa: se Deus não existe, pode-se perguntar quem é que governa a vida humana e toda a ordem na terra?

- É o próprio homem quem governa - respondeu apressadamente Biezdomni, com um ar zangado; mas a pergunta, a bem da verdade, não havia ficado bem clara para ele. (BULGÁKOV, 1992, p. 19).

Nos deparamos, nesta citação, com Ivan respondendo à questão fundamental de Woland apressadamente e sem refletir, como um bom aluno repete as falas de seu professor. A passagem lembra vagamente um diálogo tchekoviano de falas que não conduzem ao diálogo, mas ao isolamento ${ }^{23}$, e isso não à toa: não é tanto a condição humana que está verdadeiramente em jogo aqui, mas o baixo rigor dos critérios de verossimilhança do discurso de aprendiz de Ivan, o que é evidenciado nesse deslocamento da resposta em relação à pergunta. A fraqueza da formação de Ivan é também a do discurso de seu mestre, Berlioz, pelo que Woland ganhará a disputa filosófica. Se a questão “Quem governa a vida humana e toda a ordem na terra?" pode ser vista como uma pergunta pela causa final da existência - qual o sentido da existência humana e de todas as outras coisas, se Deus não existe? -, ela, ao mesmo tempo, aparece satirizada, tendo sido retirado o seu teor sério e teórico. Isso fica ainda mais evidente na réplica de Woland à resposta escolar de Biezdomni:

- Desculpe-me - respondeu suavemente o desconhecido - mas para governar é preciso possuir, no fim das contas, um plano preciso para um prazo pelo menos razoável. Quero perguntar, portanto, como o homem pode governar se ele é incapaz de elaborar um plano mesmo para um prazo ridiculamente curto, mil anos, digamos, e nem sequer pode dar uma garantia sobre o seu dia de amanhã? (BULGÁKOV, 1992, p. 19).

\footnotetext{
${ }^{23}$ Bakhtin diz ser muito característico "da menipeia as cenas de escândalos, de comportamento excêntrico, de discursos e declarações inoportunas, ou seja, as diversas violações da marcha universalmente aceita e comum dos acontecimentos, das normas comportamentais estabelecidas e da etiqueta, incluindo-se também as violações do discurso" (BAKHTIN, 2013, p. 134). Sobre Tchékov, ver: (SZONDI, 2011, p. 40-6, aqui especificamente p. 45): "O que aqui aparece como diálogo, apoiado no motivo da má-audição, é no fundo o monólogo desesperado de Andrei, que tem como contraponto as falas igualmente monológicas de Ferapont. Se na fala sobre um mesmo tema normalmente se mostra a possibilidade de um entendimento genuíno, aqui ela expressa sua impossibilidade. A impressão de divergência é tanto maior porque se destaca sobre um fundo de simulada convergência. O monólogo de Andrei não nasce do diálogo, mas surge, ao contrário, por meio de sua negação. A expressividade desse "diálogo de surdos" se funda sobre o contraste dolorosamente paródico com o verdadeiro diálogo, que ele assim relega ao plano da utopia". Essas últimas palavras sobre o contraste dolorosamente paródico com o verdadeiro diálogo ecoam neste diálogo entre Biezdomni, Woland e Berlioz.
} 
Fantástico, ironia, estranhamento e hiperbolização se misturam nessa fala de Woland pelo primado da contingência frente à racionalidade, nesta fala em que o trágico - a falta de sentido da vida humana - se traveste de cômico ao ser dito por um personagem que não se define por sua finitude temporal, ou seja, pela morte. Esta será o tema com que essa discussão irá continuar, mais uma vez nesse duplo significado sério e satírico. O dilema da causa final da existência não se resolve em existencialismo, ou seja, na inversão filosófica presente no jargão sartriano de que "a existência precede a essência" - o que seria, é claro, um anacronismo -, mas em terror, grotesco e fantástico: Woland canta o modo exato pelo qual Berlioz irá morrer nessa mesma noite. Por um lado, a confirmação de sua fala premonitória é a confirmação da vitória e do poder de Woland: nem o discurso oficial pode com o sobrenatural - que paradoxalmente não passa de uma máscara carnavalizada do regime stalinista, só que grotescamente hiperbolizado e, com isso, satirizado. Por outro lado, a morte específica de Berlioz é metonímia satírica da condição humana: é então do acaso, da fortuna, da contingência, - do demônio - a última palavra sobre o governo dos homens?

A sátira aparece mais uma vez quando Woland inse também aí uma contradição: o acaso governa os homens, mas o acaso sendo o demônio, que ele mesmo é, não pode ser para ele verdadeiramente um acaso, mas sim algo querido pela sua vontade. O cômico: o demônio é acaso em si, mas não para si. O demônio: vontade de acaso. Assim, sugerindo que a última palavra é a da sua vontade - da vontade do acaso -, Woland, de modo mefistofélico - o que obviamente não é de se surpreender -, procura reduzir o que é universal ao que é privado, ou seja, o que poderia ser voltado para o bem de todos - embora já deturpado, a saber, o gosto de mandar, o egoísmo de poder - ao egoísmo individualista, a vontade de poder à vontade de sobrevivência, num arroubo ironicamente preexistencialista ao modo de Tolstói, de Ivan Ilitch:

- Com efeito - neste momento o desconhecido virou-se para Berlioz imagine, por exemplo, que o senhor começa a governar, a mandar nos outros e em si próprio e, de um modo geral, toma gosto e, de repente... hum... hum... fica sabendo que tem um sarcoma no pulmão... - então, o estrangeiro deu um sorriso doce, como se a ideia do sarcoma no pulmão lhe fosse muito agradável - sim, um sarcoma - repetiu ele a palavra sonora, semicerrando os olhos como um gato - e lá se foi o seu governo! Nenhum destino, exceto o seu próprio, o interessa mais. (BULGÁKOV, 1992, p. 19).

Sarcoma no pulmão ou ferida no rim, mal que acomete Ivan Ilitch, a particularidade de se tratar da morte específica deste homem aqui leva o humano a se preocupar consigo mesmo, mas para o diabo essa preocupação não se abre a uma reflexão universal sobre a existência do ser humano, como ocorre com o personagem de Tolstói ou em Ser e Tempo (HEIDEGGER, 
2012), uma das influências do existencialismo sartriano, e sim ao egoísmo individualista. Particular é também a situação da questão do humano no interior das décadas de 1920 e 1930 soviéticas para a cultura oficial: ao invés da sugestão do fim da ficção "homem", como pediria Foucault mais tarde em As palavras e as coisas (FOUCAULT, 2007), assistimos na URSS a invenção de um homem - de cuja alma justamente o escritor deveria ser o engenheiro - que iria

se tornar incomparavelmente mais forte, mais sábio e mais sutil. Seu corpo será mais harmonioso, seus movimentos mais rítmicos, sua voz mais melodiosa. As formas de sua existência adquirirão qualidades dinamicamente dramáticas. A espécie humana, na sua generalidade, atingirá o talhe de um Aristóteles, de um Goethe, de um Marx. E sobre ela se levantarão novos cumes. (TROTSKI, 2007, p. 196).

Se, então, a formação do realismo socialista enquanto literatura de estado oficial visa, ao lado de políticas e propagandas oficiais, bem como de outras manifestações culturais, à constituição de uma outra ficção "homem", podemos nos perguntar: para onde a sátira paródica desta formação leva esta ficção, ao corroer a estrutura dialógica mestre-aprendiz e ao dar soluções estéticas inovadoras para os problemas de métodos representacionais no interior do desenvolvimento da prosa russa? 


\section{Entremeios (do incidental): a paródia, o elemento fáustico e o problema da união dos romances - os espaços vazios como horizonte ético do literário}

Enquanto no capítulo anterior analisamos brevemente alguns aspectos da relação paródica entre $O$ Mestre e Margarida e o romance realista socialista a partir de uma análise de algumas situações dialogais, procurando indicar o papel do fantástico no interior da renovação do método representacional operado por Bulgákov, veremos agora como esse mesmo elemento fantástico nos põe frente a frente com a dimensão paródica do elemento fáustico, sobre a qual tratamos mais detidamente neste capítulo. A paródia do romance realista socialista e do fáustico se combinam - ao lado da paródia da realidade soviética, bem como de outros elementos que não pudemos analisar mais detidamente, como a relação com autores russos modernos como Gógol, Dostoiévski, Saltikov-Schiedrin etc. -, pois, em geral, a prosa de Bulgákov não parodia uma única obra, um único arquétipo ou uma única realidade. Segundo Andrade,

Não há mais a parodização de uma única obra, de um único autor. O recurso é ampliado para outros autores e obras, bem como para situações da realidade histórica da época, fundadas no choque entre os velhos e os novos costumes e ideias, que são utilizados como elementos composicionais de um texto satírico original, não paródia de outro texto. O princípio de que se pode parodiar tudo. (ANDRADE, 2010b, p. 274).

Se em "As aventuras de Tchíchikov" encontramos a influência central da prosa de Gógol, nem sempre é possível definir o que é mais central em um texto satírico de Bulgákov, mas em outros estas se invertem e se mesclam. Assim como no texto-paródia de Gógol o título e a epígrafe remetem diretamente às Almas mortas de Gógol, O Mestre e Margarida também faz referência clara ao fáustico em seu título e em sua epígrafe. Mas se, por vezes, podemos identificar o elemento fáustico na prosa de Bulgákov, nem sempre ele está ali de modo claro ou direto: muitas vezes seu lugar é lateral, funcionando como elemento de composição das características gerais de personagens criados centralmente a partir de características de outras categorias literárias ou da vida em geral ou soviética. Ao fazer isso, o fáustico aparece como elemento que ajuda a elaborar o ambiente fantástico.

Enquanto podemos ver características fáusticas, por exemplo, tanto no professor Preobrajénski, personagem de Um coração de cachorro, como também em Piérsikov, o cientista de Os ovos fatais, nenhum deles é tão distintamente marcado como um personagem 
arquetipicamente fáustico como Woland e Margarida, por exemplo, o são (a começar pelos seus nomes). Nessas novelas, podemos dizer que a função geral do fáustico é a de ser um dos componentes que dão um tom satírico ao fantástico vertido em ficção científica, ao mesmo tempo que a dotam de uma profundidade filosófica.

No relatório médico do assistente do professor Preobrajénski - paródia, é claro, de um relatório científico propriamente dito -, por exemplo, vemos o assistente comparar este com Fausto (embora o mais "correto" seria compará-lo com Wagner): "Um novo campo se abre à ciência: sem qualquer retorta de Fausto, um homúnculo foi criado. $\mathrm{O}$ bisturi do cirurgião trouxe à vida um novo ser humano. Professor Preobrajénski, sois o Criador (borrão)" (BULGÁKOV, 2010, p. 195). Ao lado do religioso, o fáustico entra no clímax do relatório, quando o experimento extraordinário obtém êxito, servindo, assim, como um elemento que busca interpretar os acontecimentos relatados novos e extraordinários a partir de formas já conhecidas. Mas essa comparação acaba apenas dando mais vigor para a mistura de ciência, religião, literatura e magia, concedendo ainda mais teor satírico à ficção científica.

Nesta passagem também pode ser observado de modo bastante explícito como Bulgákov aproxima a questão do humano com o arquétipo fáustico - o que, aliás, também é realizado em O Mestre e Margarida; em outras obras, contudo, o fáustico está nem tanto no arquétipo dos personagens, mas principalmente na composição de situações em que sonho, percepção subjetiva e realidade se embaralham, como na seguinte passagem de $O$ romance teatral, em que o narrador em primeira pessoa sonha que Mefistófeles lhe faz uma visita:

La porta si spalancò e rimasi impietrito per terra dallo spavento. Era lui, senza alcun dubbio. Nella penombra, alto, sopra di me, apparve un volto con un naso imperioso e sopracciglia marcate. Le ombre giocavano e a me era sembrato che sotto il mento squadrato spuntasse la punta di uma barba nera.Il cappello era messo sulle ventitré fino a scoprire un orecchio. La piuma, per la verità, non c'era. Per farla breve, davanti a me stava Mefistofele ${ }^{24}$. (BULGÁKOV, 2007, p. 65).

Essa visita em sonho antecipa a visita de um personagem importante, que, como um deus ex machina de outros textos de Bulgákov (As aventuras de Tchítchikov, por exemplo), irá solucionar um impasse no desenvolvimento da trama do romance. Nesta passagem, o elemento

\footnotetext{
24 "A porta se escancarou e permaneci petrificado de espanto. Era ele, sem qualquer dúvida. Na penumbra, alto, acima de mim, apareceu um vulto com um nariz imperioso e sobrancelhas marcadas. Os ombros mexiam-se e me pareceu que sob o manto alinhado despontava a ponta de uma barba negra. O cabelo, penteado para um lado, a ponto de descobrir uma orelha. A pena, a bem da verdade, não havia. Para encurtar a história, diante de mim estava Mefistófeles." (Tradução nossa).
} 
fáustico tem a função de antecipar e reforçar o acontecimento determinante para a trama, bem como de dar arquetipicamente a importância devida a esta personagem na economia da obra.

Embora, portanto, não seja a única vez que o fantástico é preenchido por elementos fáusticos em Bulgákov, provavelmente apenas em $O$ Mestre e Margarida ele é uma influência determinante na composição do fantástico. Para ter uma dimensão dessa influência, basta ver como o elemento fáustico atua do título do romance a nomes de personagens, passando pela epígrafe e por cenas incorporadas parodicamente.

De modo semelhante com o que acontece em relação a Gógol em As aventuras de Tchítchikov, esta influência central dá uma das principais chaves com que o romance pode ser decifrado. Embora seja evidente que o fáustico não é o único elemento parodiado na obra Gógol continua sendo, de modo evidente, um deles, por exemplo -, vale assinalar que a sua importância é tanta, que até mesmo dentro do romance é determinante ter conhecimento do arquétipo fáustico: aqueles que conhecem suficientemente a história da literatura e sabem da função do demônio nos dramas fáusticos levarão vantagens definitivas em seus enfrentamentos com a trupe diabólica. Um exemplo é o diálogo já aludido anteriormente entre o Mestre e Ivan:

- Mas quem é ele, afinal? - perguntou Ivan, excitado, agitando os punhos cerrados.

$\mathrm{O}$ visitante compadecido pôs a mão no ombro do desventurado e disse:

-Poeta infeliz! Mas a culpa é toda sua, meu caro. Não podia portar-se com ele de uma forma tão ousada, descarada até. E agora você pagou por isso. E ainda deve dar graças que tudo isso tenha lhe custado relativamente pouco.

- Mas quem é ele, afinal? - perguntou Ivan excitado, agitando os punhos cerrados.

[...] - Ontem no lago do Patriarca, o senhor encontrou-se com Satanás. [...] Pois é... Mesmo a fisionomia que o senhor descreveu... Olhos diferentes, sobrancelhas! Desculpe-me, mas talvez o senhor nem sequer ouviu a ópera Fausto? [...] Pois é, pois é... não é de se admirar! Mas Berlioz, repito, surpreendeu-me. É que ele não só era uma pessoa lida, mas também muito astuta. (BULGÁKOV, 1992, p. 149-50).

$* *$

Assinalada a validade do tema no estudo da obra, precisamos tratar da paródia no âmbito da relação com o fáustico antes de adentrar na análise comparativa de texto, já que esse tópico tem certa relevância entre os comentários especializados do romance. Há alguns mal-entendidos que precisam ser esclarecidos, bem como algumas posições que precisam ser tomadas e reforçadas, antes que avancemos para a análise propriamente dita. Com isso, teremos 
oportunidade de abordar mais detidamente a noção de paródia, extremamente importante para o estudo de $O$ Mestre e Margarida.

Como considerar seu caráter fáustico? Deveria o romance de Bulgákov ser tão facilmente compreendido como uma paródia do Fausto de Goethe? Em 1987, Barratt explora essa questão ao criticar a aceitação ingênua e inquestionada de que estamos lidando com uma paródia do arquétipo fáustico clássico - o título do capítulo que trata do tema em seu livro, Between two worlds: a Critical Introduction to "The Master and Margarita" ${ }^{25}$, deixa isso bem claro: "Beyond Parody: the Goethe Connection" ${ }^{26}$, título que, aliás, é o mesmo do artigo em que retoma o tema em 1996.

Embora encontremos mudanças no percurso argumentativo entre um texto e outro, a questão que os guia e a interpretação dela nos dois textos parece ser a colocada pelo mais antigo deles: "to what extent is The Master and Margarita to be considered a 'Faustian' novel? What is at issue here is not so much the individual characters and their respective fates, nor even the plots of the two works, but such larger abstractions as theme, philosophy and vision" 27 (BARRATT, 1987, p. 270). O de 1996 já parte dessa questão, dando, em sua frase inicial, um encaminhamento a ela: "The first (and deepest) level of similarity between The Master and Margarita and Goethe's Faust lies in their overall cosmology" 28 (BARRATT, 1996, p. 113). Seu expediente, em ambos os textos, será o de estabelecer uma ligação paródica entre uma obra e outra, da qual, no entanto, não segue logicamente que os temas e visões de mundo de ambas sejam distintos: "I shall attempt to demonstrate below, it is quite possible to read The Master and Margarita as 'parody' at the first level without attributing a parodic thrust to the novel as a hole" ${ }^{29}$ (BARRATT, 1987, p. 271). Pelo contrário, se seu argumento estiver correto, diz Barratt, então deveríamos ver "Bulgakov's novel as one of the most complex and imaginative reworkings of the Faust theme since Goethe himself" 30 (BARRATT, 1987, p. 271). Ou seja, haveria níveis em que a paródia funcionaria invertendo as características fáusticas do texto

\footnotetext{
25 "Entre dois mundos: uma introdução crítica a 'O Mestre e Margarida'." (Tradução nossa).

26 “Além da paródia: a conexão com Goethe.” (Tradução nossa).

27 “Quanto podemos considerar $O$ Mestre e Margarida um romance 'fáustico'? O que está em questão aqui não é tanto os personagens individuais e seus destinos, nem mesmo as tramas das duas obras, mas abstrações maiores tais como tema, filosofia e visão." (Tradução nossa).

28 "O primeiro (e mais profundo) nível de similaridade entre O Mestre e Margarida e o Fausto de Goethe reside em suas cosmologias gerais.” (Tradução nossa).

29 “Irei tentar demonstrar a seguir que é bem possível ler O Mestre e Margarida como 'paródia' no primeiro nível sem atribuir uma essência paródica ao romance como um todo.". (Tradução nossa).

30 "O romance de Bulgákov como uma das retomadas mais complexas e imaginativas do tema fáustico desde o próprio Goethe.” (Tradução nossa).
} 
original - que ele assume ser o texto goethiano -, e níveis em que não há essa inversão, e, portanto, para ele, a paródia não estaria sendo operada. Tendo essa argumentação como a base a partir da qual realiza um estudo comparativo de diversos aspectos fáusticos no romance de Bulgákov - como o papel do demônio, o herói e a heroína, bem e mal, cosmologia geral etc. , sua conclusão é a repetição da mesma frase nos dois textos:

It's here that the basic similarity with Goethe's Faust resides. Where Goethe tells us that to strive is to err, Bulgakov implies that to strive is to fail. In each case it is the striving that proves in the end to be the crucial thing. For both authors, therefore, even the most grave human failing do not automatically warrant the punishment demanded by the naive apocalyptic mind, for such failings are viewed as an inevitable consequence of life in an imperfect world ${ }^{31}$ (BARRATT, 1996, p. 115) (BARRATT, 1987, p. 290).

Entretanto, e sem deixar de destacar a capacidade de elucidar o movimento do romance de Bulgákov ao mesmo tempo próximo e distante do Fausto de Goethe, talvez seja preciso aprofundar mais a noção de paródia - em busca de uma que possa dar conta por si só desse movimento -, bem como alargar e problematizar o sentido do fáustico em $O$ Mestre $e$ Margarida, não se limitando ao drama goethiano, com o que as próprias categorias - aspectos literários como personagens, enredo, situações, e aspectos filosóficos, visão de mundo e moral - desse movimento paródico-não-paródico serão problematizadas.

Além da questão do tipo de relação entre O Mestre e Margarida e o Fausto de Goethe, é preciso assinalar que, embora a epígrafe seja oriunda do Fausto do autor alemão, o romance tem relações com outras obras da tradição fáustica e dramática em geral. É possível encontrar principalmente a presença da ópera de Gounout, à qual Bulgákov teria assistido repetidas vezes (ANDRADE, 2002, p. 25) e também a da de Hector Berlioz (1803-1869), o músico romântico "real". A presença de elementos fáusticos em Gógol, em Dostoiévski e outros autores também pode marcar $O$ Mestre e Margarida.

\footnotetext{
31 "É aqui que reside a similaridade básica com o Fausto de Goethe. Onde Goethe nos diz que empenhar-se é errar, Bulgákov sugere que empenhar-se é falhar. Em ambos os casos é o empenho que no final é o crucial. Para ambos os autores, portanto, até mesmo a falha humana mais grave não garante automaticamente a punição exigida pela concepção apocalíptica ingênua, já que tais falhas são vistas como uma consequência inevitável da vida em um mundo imperfeito." (Tradução nossa).
} 
O fáustico não apenas remete a um ambiente cultural e operístico típico da elite cultural russa e europeia de fin de siècle, como vale também como um recurso formal utilizado por Bulgákov que acentua o tom cômico e, em alguns casos, grotesco no decorrer da obra. A relação estabelecida pelo narrador com diversas óperas dá plasticidade e comicidade à narrativa, exatamente como ocorre no momento em que Ivan Biezdomni está indo nu à sede da MASSOLIT, após sua malfadada tentativa de ir atrás da trupe diabólica que teria causado a morte de Berlioz, e de todas as janelas e reentrâncias, que se encontravam abertas, "vinha o berro rouco da polonaise da ópera Evgeni Onegin" (BULGÁKOV, 1992, p. 60). No último parágrafo do quarto capítulo, o narrador afirma: "E em todo este seu difícil percurso teve que suportar o martírio da orquestra onipresente que servia de acompanhamento a uma pesada voz de baixo que cantava o seu amor a Tatiana" (BULGÁKOV, 1992, p. 61). O narrador estabelece o acompanhamento musical de fundo do motivo satírico do homem que percorre Moscou nu na entrada da noite de primavera, introduzindo uma dimensão parodística musical na mídia escrita e explorando os limites entre o som diegético e extradiegético. Com isso, acentua e dramatiza a experiência negativa pela qual o personagem nu está passando nesse momento da narrativa, ao mesmo tempo em que introduz uma mediação de caráter cômico com essa experiência.

Mas as análises do romance exploram essa relação especificamente entre ele e a tragédia de Goethe: levados pela indicação do nome dos personagens, tende-se a querer pensar em que os personagens do romance russo diferem dos personagens homônimos de Goethe. Em alguns casos, não há homônimos, o que dá pano para muita manga: quem seria o Fausto em $O$ Mestre e Margarida? Ao focarem este problema, acabam se limitando à Primeira Parte da tragédia e ao drama amoroso, deixando de lado uma série de outras possíveis relações entre as duas obras.

Após Berlioz perder a cabeça, a trama da parte moscovita do romance gira em torno da busca por uma moradia para e pela trupe diabólica, assim como do pretenso motivo de sua visita: o show de magia negra que realiza no Teatro de Variedades. Enquanto são expostas e aprofundadas cômica e grotescamente questões da realidade soviética surgidas no primeiro capítulo no estabelecimento dos seres fantásticos no antigo apartamento de Berlioz, o show de magia negra evidencia e satiriza a ideologia soviética oficial, explorando a relação paródica entre técnica e magia, que se desdobra também na relação entre mudança material e criação de um novo humano. Essa exploração ocorrerá, entre outras coisas, por meio da criação mágica de dinheiro, que retoma o início da Segunda Parte de Fausto.

No teatro, logo após o número circense dos ciclistas, Jorge Bengalski, o animador, anuncia que "o famoso artista estrangeiro, Monsieur Woland, vai apresentar um show de magia 
negra!” (BULGÁKOV, 1992, p. 133). Em seguida, as cortinas se separam, “deslizando com ligeiro barulho em sentidos opostos" e entra o mágico, "acompanhado pelo seu ajudante compridão e pelo gato que andava sobre as patas traseiras" (BULGÁKOV, 1992, p. 133). Woland ordena uma poltrona, que surge no palco não se sabe de onde, e então faz uma pergunta fáustica a Koroviev-Fagot, o seu ajudante compridão: “- Diga-me, estimado Fagot [...], na sua opinião, a população moscovita mudou muito?” (BULGÁKOV, 1992, p. 134).

Koroviev, que é neste momento pela primeira vez chamado de Fagot, responde que sim, que ela mudou muito. Ao que Woland responde: “- Você tem razão. Os citadinos mudaram bastante... Refiro-me ao seu aspecto externo, da mesma maneira que toda a cidade, aliás. Do vestuário nem se fala, mas surgiram esses... como é mesmo... bondes, automóveis...”. A conversa prossegue até chegar ao ponto central. Woland diz:

- Mas é claro, o que me interessa sobretudo não são os ônibus, os telefones ou outra...

- Aparelhagem - sugeriu o de xadrez.

- Exatamente isso, agradeço - pronunciou o mágico lentamente, em voz baixa e grave - mas eis uma questão muito mais importante: será que esses cidadãos mudaram no seu íntimo? (BULGÁKOV, 1992, p. 134-5).

Como uma investigação mágico-científica, o show de magia negra irá prosseguir na tentativa de responder a essa questão, fazendo surgir notas de rublos nos bolsos da plateia que aos poucos se convence de que aquilo não é exatamente apenas um truque de magia já manjado, mas magia de verdade. O mais impressionante é que isso não os assusta, porque o que interessa mesmo é que o dinheiro, como a magia, também é autêntico.

Podemos ver uma relação direta desta cena com o projeto mefistofélico de recuperação econômica do Império, que ocorre no Primeiro Ato da Segunda Parte do drama alemão. Nela, Mefistófeles faz do "Papel, em vez de ouro e prata, um bem" (GOETHE, 2008b) (v. 6120). Logo após o ato de Mefisto, o Imperador distribui a nova quantidade exorbitante de dinheiro entre seus sequazes, exigindo: "Membros da Corte ora com dons contemplo./ Dê-me cada um de seu emprego o exemplo" (v. 6143-4). O exemplo, no entanto, não é muito animador: "Dia e Noite andarei me divertindo" (v. 6145). O Imperador chega à conclusão então de que não houve mudança alguma no íntimo das pessoas, sendo possível ver nessa prova da essência imutável humana a conexão da função do motivo do dinheiro nas duas obras: "Julguei ver de altos feitos novo afã;/ Mas vos conheço: era esperança vã./ Vê-se que com o tesouro todo, pois,/ Sempre continuareis sendo o que sois.” (v. 6151-4). A única exceção é o bobo da corte e, em certo 
sentido, o Mestre. Enquanto aquele compra terras com os dons que ganhou, o segundo, tendo ganhado na loteria, passa a usar seu tempo para escrever a narrativa de Pilatos.

Para Binswanger, o Bobo se mostra como o único que percebeu o caráter irreal do papelmoeda que o alquímico Mefistófeles cria para sanar as dívidas do imperador ao querer ver "materializado" o seu valor, se precavendo assim da necessariamente vindoura inflação (BINSWANGER, 2011, p. 73-5). Ele é o único que age levando em conta um dos critérios de valor do papel-moeda - o lastro material do ouro enterrado. Em O Mestre e Margarida parece estar em jogo o outro dos critérios de valor que dá valor ao papel-moeda: em Fausto, a assinatura do imperador; no romance russo, o aval dos órgãos oficiais personificados por Berlioz e pela burocracia estatal do teatro de variedades. Vale dizer que são essas as instâncias atormentadas pelas forças demoníacas durante sua passagem por Moscou. Aqui parece estar em questão mais o lastro como o lugar de fala que gera valor do que o problema econômico do valor propriamente dito: o lastro como aquilo que cola a especulação do terreno da possibilidade futura no presente do que existe.

A questão do lugar de fala remete não somente à desconstrução paródica das instâncias burocratizadas de produção de verdade e de garantia de seu valor, mas também à discussão inicial entre Woland e Berlioz a respeito da existência de deus. Heidegger defende que a expressão nietzschiana “deus está morto" está diretamente correlacionada à questão do critério de valor moral e de verdade da tradição metafísica (HEIDEGGER, 2002, p. 250-1). Dizer que deus está morto significa denunciar, do ponto de vista do problema do lastro acima aludido, a invalidez da assinatura do imperador; no caso do que Heidegger e Nietzsche chamam de tradição metafísica ou platônica, o caráter de hipóstase da régua (deus) do eterno que mede e dá valor ao temporal, do infinito ao finito, do bem ao mal, e assim por diante:

O dito "Deus morreu" significa: o mundo supra-sensível está sem força atuante. Ele não irradia nenhuma vida. A metafísica, isto é, para Nietzsche, a filosofia ocidental compreendida como platonismo, está no fim. [...] A metafísica é o espaço histórico no qual se torna destino que o mundo suprasensível, as ideias, Deus, a lei ética, a autoridade da razão, o progresso, a felicidade da maioria, a cultura, a civilização, percam a sua força edificadora e se tornem nulos. Chamamos esse desmoronamento essencial do suprasensível a sua decomposição. (HEIDEGGER, 2002, p. 251-5).

A assinatura é um problema da criação do papel-moeda no Fausto que, embora Binswanger não analise em seu Dinheiro e magia, é fundamental para pensar a noção de valor: se a régua - a assinatura - com a qual posso dar realmente valor ao que tem valor é ficcional, significa que o que garante que determinada ficção seja posta no lugar do critério do valor de 
real tenha de ser o poder daquele que é capaz de determinar qual afinal é a medida das coisas que valem como reais. Uma possibilidade de conservação dessa estrutura conceitual seria (e)levar o homem a se tornar ele mesmo a hipóstase. É isso que faz Sartre, para Heidegger, que recusa o humanismo e é isso também o que Foucault está acusando no final de As palavras $e$ as coisas: recusa e acusação que se dão por entenderem que seria preciso não apenas aceitar a morte de deus como a morte do critério de valor, mas também e principalmente como a transvalorização e declínio do valor de todos os valores, ou seja, como uma necessidade de se romper com a estrutura metafísica judício-valorativa. Com isso, é o real enquanto real que está em jogo, cuja essência Heidegger, interpretando Nietzsche, vê na vontade de poder como o princípio de onde a instauração de valores sai e se mantém, porque essência da lógica de asseguramento e acúmulo de "domínio" própria ao que é vivo (HEIDEGGER, 2002, p. 264-6): "a essência da vontade de poder é, enquanto essência da vontade, o traço fundamental de tudo o que é efetivamente real" (HEIDEGGER, 2002, p. 272).

Quando Berlioz afirma que Jesus não existiu, ele está não apenas defendendo um ponto de vista, mas assinando o papel (não mais moeda aqui - mas talvez uma carteirinha que garante privilégios no clube do escritor, ou seja, que tem valor material), colocando a si mesmo como representante de uma instituição oficial como critério de valor da verdade. De certo modo, a operação paródica da entrada de Woland é então tanto uma expressão de poder (Nietzsche falaria em vontade de poder) que só pode ocorrer no âmbito da pura ficção - e esse elemento fantástico é tipicamente uma marca moderna do romance, que se afirma e se mostra como ficção (ficção, nesse caso, entendida como falsidade) -, como também um desmascaramento dessa assinatura burocrática oficial. É por isso que Woland afirma que "não é preciso nenhuma prova".

Mas o interessante de $O$ Mestre e Margarida é que o problema não para simplesmente aí. Em primeiro lugar, é preciso uma prova: o papel-manuscrito do romance do Mestre, ou seja, a materialidade ou lastro (analisados por Binswanger) do texto e seus critérios de produção e de circulação; em segundo lugar, essa exposição paródica dos critérios de verdade do discurso oficial soviético desemboca em uma importante mudança de concepção, a saber, a de temporalidade. Abandonar o "humano" como critério de valoração de verdade significa abandonar o ideal de progresso eterno que caracteriza o mundo moderno, o qual pode ser visto como "a vitória parcial da economia sobre o tempo" (BINSWANGER, 2011, p. 151). É esse ideal de "[transformar] bens em valores monetários que sobrevivem à passagem do tempo" (BINSWANGER, 2011, p. 151) que move Fausto a expulsar Elêmon e Baucis de sua choupana 
e que fará com que a utopia do Mestre seja a de descansar em uma "choupana". Se Fausto vê a forma arcaica de economia dos anciãos como "um estorvo decisivo ao progresso rumo à economia moderna" (BINSWANGER, 2011, p. 157), o romance do Mestre é também um estorvo decisivo rumo à valorização do valor soviético oficial, porque ambos situam-se fora da estrutura de valorização ${ }^{32}$.

Há ainda uma outra consequência em relação à temporalidade nesse processo de expor a ficcionalidade da assinatura - a de romper com a temporalidade do presente e da presença. Poderia ser que $O$ Mestre e Margarida sugerisse então uma volta ao critério de valor tradicional, a não morte de deus. Com o romance dentro do romance do Mestre e com a existência explicitamente ficcional do demônio, pode parecer que as coisas estão definidas aí. Mas a narração de um Jesus histórico não convencional sugere que tenhamos algum cuidado aqui. Mesmo sem adentrar propriamente no romance dentro do romance (o que reservamos para o último capítulo), podemos dizer que se trata de uma reapropriação do passado que busca ressignificá-lo na potencialidade de outros futuros.

Na relação entre Jesus e Pilatos tematizada no romance do Mestre, podemos entrever a possibilidade existente no passado de responder responsavelmente ao problema da crise do valor dos valores - ou seja, à morte de deus -, ao se confrontar com o poder da assinatura. Como fica evidente no diálogo (que será analisado no próximo capítulo) em que Jeshua diz a Pilatos que este está com dor de cabeça, o lastro ou a assinatura de Jeshua são suas ações (éticas) e as consequências desses seus atos (de fala). É isso o que percebe Berdiaev comentando a defesa de liberdade de consciência operada por Dostoiévski e sua visão de cristianismo em seu Dostoievsky: an interpretation (1934), que data da mesma época em que $O$ Mestre e Margarida estava sendo redigido: "In Christ there is no forcing of conscience [...]. He used no coercion to make us believe in him as in God, he had not the might and majesty of the sovereigns of this world, the kingdom that he preached was not here" 33 (BERDIAEV, 2009a, p. 78-9). Mas a diferença fundamental de $O$ Mestre e Margarida em relação a Berdiaev é que, no romance, Jesus não nos "faz acreditar nele como Deus", mas faz as pessoas, e principalmente Pilatos, acreditarem simplesmente nele graças a algo não convencional de suas atitudes. Nessa pequena

\footnotetext{
32 "A economia de Filêmon e Baucis, a forma modesta de economia determinada pela natureza, precisa ser destruída. Fausto a vê como um estorvo decisivo ao progresso rumo à economia moderna, que ele escolheu, já que o impede de encontrar a felicidade em sua visão de progresso eterno.” (BINSWANGER, 2011, p. 157).

33 “Em Cristo não se força a consciência [...]. Ele não usou da coerção para nos fazer acreditar nele como em Deus, ele não tinha o poder e majestade dos dominadores deste mundo, o reino que ele pregava não era daqui." (Tradução nossa).
} 
diferença pode residir talvez o que há de mais significativo do romance de Bulgákov em relação ao seu tempo.

Berdiaev engajava-se na disputa da inversão dos termos deus-homem e homem-deus que ocupou muitos dos expoentes russos desde Dostoiévski - que teria cunhado os termos em russo -, fazendo uma defesa de Cristo como o deus-homem. Deus-homem é visto como Cristo, o deus que se tornou homem, contra o que ele e outros autores viam no ideal niilista iniciado lá nos idos 1860 com Bazárov, um dos personagens centrais de Pais e filhos, do homem-deus, o homem que se torna deus ${ }^{34}$. Do ponto de vista do problema da assinatura e da morte de deus como a morte do valor de todos os valores acima aludido, Berdiaev parece, nesse sentido, ainda

\footnotetext{
${ }^{34}$ Há diversos estudos sobre isso que cito aqui a seguir e que ajudaram a desenvolver o caminho de argumentação desta dissertação, mas que não foram diretamente citados. Sobre a influência de Nietzsche nos "buscadores de deus", i.e. aqueles que buscavam manter deus como valor dos valores, (GRILLAERT, 2008). Esse estudo é capaz de mapear bem o desenvolvimento histórico da discussão sobre os temas deus-homem e homem-deus desde Dostoiévski, bem como sugerir como a presença de Nietzsche fora importante para reorganizar o contexto do debate. No último capítulo, ainda explora a relação de Berdiaev com a noção de Übermensch de Nietzsche, e por isso pode valer como um dos textos-base para quem quer estudar nem tanto apenas a influência de Dostoiévski sobre Nietzsche, mas também o caminho contrário, a presença de Nietzsche sobre os russos em contexto dostoievskiano. Já o artigo de (KRASICKI, 2002) sugere que essa tradição da renascença religiosa russa já apontava para o abandono do "humano" e do humanismo, a contrapelo da filosofia alemã da mesma época, e situa a discussão acima aludida dentro de questões do pensamento nietzschiano e heideggeriano. Por fim, (MEERSON, 1995) é capaz de mapear o ambiente kantiano e neokantiano desses autores russos da renascença religiosa (que teriam influenciado Bakhtin e Bulgákov) que também compunha o contexto da discussão que travavam. Essa discussão é praticamente desconhecida no Brasil, em parte graças ao pouco (ou nenhum) espaço para estudos de filosofias não europeias nos departamentos de filosofia (e quando há algum espaço, este está tomado pelo estudo de autores da tradição oriental oriundos principalmente da Î́ndia, China e Japão), em parte devido talvez a razões de interesse dos estudantes de cultura russa. Um exemplo recente disso ocorreu por ocasião do XV Encontro Nacional da Associação Brasileira de Literatura Comparada (ABRALIC), no qual houve uma fala no grupo de trabalho 23 "Estudos da literatura russa no Brasil: Crítica, comparatismo, tradução" que buscava relacionar a noção de niilismo na Rússia e no Brasil. Nesta tentativa, a expositora deixou de lado toda a tradição desses autores pósDostoiévski. Outro exemplo, oriundo dos departamentos de filosofia, da necessidade de um aprofundamento nesses autores pode ser visto em (GIACOIA JÚNIOR, 2006) que traça a relação entre Nietzsche e Dostoiévski, apontando a importância de Dostoiévski para uma interpretação psicologizada de noções como de ressentimento em Nietzsche, mas deixando de lado completamente como uma tradição dostoievskiana recepcionaria e responderia a Nietzsche. Embora esse tema seja um objeto apenas oblíquo ou paralelo aos estudos desta dissertação, espero poder apontar aqui para a necessidade de estudos desses autores que abordem de uma maneira bastante particular e significativa noções como as de humano, humanismo, socialismo, catolicismo, anarquismo etc. - Bulgákov (assim como Bakhtin), com toda certeza, viveu num ambiente em que esses autores vigoravam (ele, por exemplo, assistiu a um curso de Florenski sobre sua concepção ao mesmo tempo cristã ortodoxa e científico-matemática a respeito da perspectiva e da quarta dimensão) e $O$ Mestre e Margarida carrega em seu bojo a presença deles. Como veremos a seguir e principalmente de forma mais detida no terceiro capítulo, procuro reivindicar um lugar independente para Bulgákov (e também para Bakhtin) entre os dois lados do debate, ao mesmo tempo que reconheço a importância dessa presença para o modo particular e significativo com que Bulgákov lida, por exemplo, com o problema do humano, ou ainda com o elemento fáustico. Poucos comentadores aproximam o romance desse momento da história das ideias da Rússia - os três principais críticos com quem dialogamos neste estudo (Barratt, Strada e Weir) não o fazem; quando o fazem, deixam de lado uma análise formal do romance de maneira mais detida. Aqui, procurei desenvolver a análise literária em paralelo ao apontamento de algumas questões da história das ideias russa (uma espécie de relação entre literatura e sociedade em que sociedade é compreendida não a partir da sociologia e da política, mas da história das ideias), o que nem sempre foi possível realizar da forma como gostaria. Esta nota visa preencher (como uma sombra sugestiva) a lacuna que senti durante o processo de finalização do texto desta dissertação de exposição do horizonte de ideias no qual o romance ao mesmo tempo está inserido e ao qual se contrapõe, de alguma maneira.
} 
garantir a estrutura dual que pode ser preenchida ou pelo deus-homem, Jesus, ou pelo homemdeus, Anticristo. Ele diz, por exemplo, que

The thing which Dostoievsky and Nietzsche knew is that man is terribly free, that liberty is tragic and a grievous burden to him. They had seen the parting of the ways in front of mankind, one road leading to the God-man, Jesus Christ, the other to self-deification, the man-god. ${ }^{35}$ (BERDIAEV, 2009a, p. 62-3).

A pequena mudança de $O$ Mestre e Margarida aponta para a possibilidade de uma superação desse dualismo teológico e de dação de sentido; superação pela transformação da questão moral do bem e do mal em um problema ético da assinatura do papel-ficção. Além disso, porque a história de Jesus não é um sonho, como em Dostoiévski, mas um romance dentro do romance, que aparece exatamente tal como ele teria sido escrito por seu escritor ficcional, o Mestre, ela nos permite ver a possibilidade de futuro(s) contido(s) no passado que pode(m) ser ativado(s) através da sua interpretação, o que, aliás, é exatamente o que as boas novas (os evangelhos) fizeram - aí a hermeneuticidade (não tão ortodoxa) do romance entrevista por Weir. Esta possibilidade que desloca o tempo do presente e da presença metafísica do progresso (o "é" ôntico das afirmações em que se baseia toda a metafísica e a física enquanto ciências do que é) é a abertura de imponderabilidade do futuro apontada por Woland: a abertura poética a rosa do asfalto - da ficção-fantasia do ser humano, do que pode ser (do humano), e é também uma restituição da finitude e do direito de morrer ao ser humano.

Embora a ficção-fantasia seja vista como aquela arte capaz de instaurar e ressignificar valores, ao mesmo tempo esta capacidade já está mediada pelo problema da verdade compartilhada num âmbito em que a verdade tem como critério a vontade de poder. Com Jeshua "desconstruído" das interpretações evangelistas (e, ao mesmo tempo, sendo construído enquanto uma interpretação apócrifa dela) - o que Heidegger já admitia ser possível ao diferenciar Christientum de Christlichkeit ${ }^{36}$ - O Mestre e Margarida põe a questão do lugar de

35 “O que Dostoiévski e Nietzsche sabiam é que o homem é terrivelmente livre, que a liberdade é trágica e um fardo penoso para ele. Eles viram a partição dos caminhos na frente da 'humanidade', uma via que levava ao Deushomem, Jesus Cristo, e o outro à autodeificação, o homem-deus.” (Tradução nossa).

36 “Daí também que o niilismo, no sentido de Nietzsche, de modo nenhum se confunda com o estado, representado de um modo meramente negativo, de já não se poder crer no Deus cristão da revelação bíblica, tal como Nietzsche por cristianismo não compreende a vida cristã que havia em tempos, no curto tempo antes da composição dos Evangelhos e antes da propaganda missionária de Paulo. O cristianismo é para Nietzsche o fenômeno histórico e político-mundial da Igreja e da sua reivindicação de poder dentro da configuração da humanidade ocidental e da sua cultura moderna. O cristianismo, neste sentido, e a cristandade da fé no Novo Testamento não são o mesmo. Também uma vida não cristã pode afirmar o cristianismo, e usá-lo como fator de poder, tal como, ao contrário, uma vida cristã não precisa necessariamente do cristianismo. Daí que uma confrontação com o cristianismo não 
fala e da efetividade ética da fala e daquele que fala como um "passo posterior" (no sentido mais cru de Fortschritt) do próprio preparar da questão do niilismo de Heidegger interpretando Nietzsche e com isso se aproxima do Foucault que pensa a parresía e, como estamos tentando pensar aqui, também de Bakhtin.

$* *$

Levando em conta o motivo carnavalesco que perpassa todo o Primeiro Ato da Segunda Parte de Fausto, percebemos que há um campo pouco explorado da relação entre $O$ Mestre $e$ Margarida e a Segunda Parte do drama alemão que pode abrir diversas perspectivas comparativas.

Mantendo-nos nas relações entre os personagens a fim de dialogar com a crítica anterior, é possível, nesse sentido, defender que a relação de Woland e de Margarida com o drama alemão é muito mais complexa do que normalmente se percebe quando os associamos diretamente com Mefistófeles e Gretchen. Vale lembrar aqui que o procedimento paródico da prosa de Bulgákov é o de um jogo complexo de relações múltiplas em que a relação entre o parodiado e o que parodia não pode ser entendida como uma relação apenas dual, de "inversão", mas sim como uma relação múltipla e complexa entre diversos textos ou realidades que se conectam e se desconectam, que se aproximam e se afastam.

E o Primeiro Ato da Segunda Parte do drama de Goethe é um lugar privilegiado para encontrar outros elementos que compõem o Mefisto russo. Nesta cena, Mefisto aparece mascarado como $\mathrm{O}$ Avarento e, em determinado momento, dá a forma de falo a um metal, já que "a mímica [...] é insuficiente" (v. 5779). Com isso, associa o ouro à sexualidade, sugerindo serem esses elementos que determinam a imutabilidade da essência humana. Esse é de fato um tema caro à obra de Goethe, mas ele não está presente de modo central no romance russo. Isso nos leva a perceber que, diversamente do que pode parecer, o fato de a paródia expandir a mera relação de inversão de apenas um texto em Bulgákov não quer dizer que tudo e qualquer coisa são conectados nessas relações múltiplas. Além disso, há diferenças significativas entre Woland e Mefisto que têm de ser mais bem tematizadas pela crítica.

seja de modo nenhum e necessariamente um combate contra o que é cristão, da mesma maneira que uma crítica da teologia não é ainda uma crítica da fé, de que a teologia deveria ser a interpretação. Movemo-nos sempre nos terrenos dos combates das mundividências enquanto desprezarmos estas diferenciações essenciais." (HEIDEGGER, 2002, p. 254). 
Ao contrário de Meu Fausto (1945) de Valéry, o tema da luxúria, sugerido pelo nome Lust, a mais próxima de ser a Margarida valeriana, é então muito pouco explorado em $O$ Mestre e Margarida. Helles, a ajudante de Woland, símbolo da luxúria em Moscou, tem papel apenas secundário na trama. A aproximação do Mestre com a Margarida não é em momento algum explorada como uma vontade de luxúria do Mestre que posteriormente teria se elevado a um amor mais espiritual, intelectual ou artístico do que carnal. Além disso, as cenas de nudez e de vaidade de Margarida expõem uma experiência do corpo e da sexualidade em outra chave conceitual em relação à Gretchen. Talvez a principal diferença esteja em que Margarida não parece sentir uma relação de culpa com seu corpo e sua sexualidade, dando a entender que amor e sexualidade, corpo e espírito, são compreendidos mais como complementares do que como opostos:

- Isto que é creme! Que creme! - gritou Margarida lançando-se na poltrona. As fricções não alteraram só o seu aspecto físico. Agora, em todo o seu ser, em cada partícula de seu corpo, fervia a alegria, que ela sentia como bolinhas que a picavam. Margarida sentia-se livre, livre de tudo. (BULGÁKOV, 1992, p. 251-2).

Sendo então o corpo não experienciado a partir da perspectiva do falo, a Margarida russa está longe da Lust de Valéry como aquela Margarida de sua época que recupera fundamentalmente a questão da sexualidade da Margarida goethiana. Mas isso não quer dizer que então Woland e Margarida não devem mais nada ao drama de Goethe. Um dos temas centrais do romance de Bulgákov é a relação entre fantasia e realidade, e nem Woland nem Margarida escapam desse problema do ponto de vista de sua genealogia. Woland é quem leva a fantasia a Moscou e a personifica. Na mascarada do drama alemão, é o Mancebo-Guia quem usa a máscara da Poesia, dizendo: "Eu sou o Pródigo, a Poesia/ Meus bens esbanjo; sou o Poeta,/ Que em derramar dons se completa" (GOETHE, 2008b, p. 143) (v. 5572-5).

No Teatro de Variedades, Woland não apenas cria magicamente papel-moeda, mas também mercadorias que serão distribuídas entre a plateia, tal como o faz o Mancebo-Guia que "lança à multidão" a riqueza que "provém da força da imaginação, do caráter ficcional da poesia":

Vês-me a estalar o dedo agora, logo cintila o carro afora.

Ricos colares desenrolo!

(continuando a estalar os dedos à roda) Pérolas para a orelha e o colo, Espelhos de ouro, diademas, 
Ricos anéis, preciosas gemas.

Também dôo uma ou outra chama,

A aguardar onde ela algo inflama (GOETHE, 2008b, p. 144).

E o Arauto, em seguida, descreve o que acontece com tais riquezas:

\author{
A turba como pega e agarra! \\ Quase que no doador esbarra. \\ Como num sonho as gemas solta, \\ E tudo a safra apanha em volta. \\ Mas ora um novo truque observo: \\ Por mais que alguém pegue no acervo, \\ O prêmio não é muito bom! \\ Vai voando embora o rico dom, \\ Em pó desfazem-se os tesouros, \\ formigam-lhe na mão besouros (GOETHE, 2008b, p. 144) (v. 5582 a 5601).
}

O mesmo se passa em Moscou com o papel-moeda e as riquezas distribuídas por Woland, causando todo tipo de mal-entendido e embaraço pela cidade. Em certa medida, podemos dizer então que Woland é uma mistura de Knabe Lenker (Mancebo Guia) e Mefistófeles: é também a alegoria da Poesia - da fantasia - e distribui seus "bens", que desaparecem por não serem materiais. A sátira bulgakoviana, nesse sentido, parece empenhada em escrachar não o gosto burguês, mas soviético.

Já quanto à Margarida, podemos ver ressoar nela a disputa entre as flores oriundas da natureza e as artificiais, da fantasia. O Mestre e a Margarida se encontram pela primeira vez porque ela "levava nas mãos", segundo o Mestre, "flores repugnantes, de uma inquietante cor amarela" (BULGÁKOV, 1992, p. 153). A relação entre os dois se inicia quando o Mestre responde, de modo sincero, com uma negativa, à pergunta dela se ele gosta das flores que ela tem nas mãos.

É essa sinceridade entendida como o aspecto natural e fresco dos botões de rosa frente à fantasia artificial das flores artificiais que vai levar à aproximação entre os dois, já que ele não se sente acanhado de dizer que não é que não goste de flores em geral, mas sim, em particular, dessas, e que, na verdade, dentre os vários tipos de flores, gosta de rosas. Talvez porque, como dizem os Botões de Rosa do drama goethiano, "Ao brotar o ar de verão,/ da rosa abre o botão./ Quem iria dispensar tal felicidade?/ No âmbito da Flora rege/ A promessa, a concessão/ Igualmente olhar e sentido e coração" (GOETHE, 2008b, p. 98-9) (v.5152-7). Transpondo para o romance russo "a promessa e a concessão" que seguem em paralelo a olhar, sentido e coração, podemos entender que o amor (olhar, sentido e coração) que ocorre entre o 
Mestre e a Margarida está em ligação íntima com a sinceridade e franqueza (a promessa e a concessão) da relação entre eles.

A paródia do fáustico em $O$ Mestre e Margarida, mesmo se circunscrita unicamente ao drama de Goethe, se mostra mais complexa do que uma mera inversão dos papéis e do sentido geral da obra parodiada. Na seguinte passagem, Andrade contrapõe dois sentidos de paródia a partir de uma contraposição do prefixo grego para entre seus sentidos de contra, anti e de ao lado de, junto de:

No processo da parodização, os modelos artísticos são destruídos e, paradoxalmente, renovados. No caso da obra literária - como resume F. Kothe à luz de teóricos do formalismo russo -, a paródia "é um texto que contém outro texto em si, do qual ela é uma negação, uma rejeição e uma alternativa. [...] A paródia é um texto duplo, pois contém o texto parodiado e, ao mesmo tempo, a negação dele". Tem-se aqui a definição do termo como "contracanto". Mas há um significado da palavra, ao qual os teóricos do assunto quase nunca dão a devida importância e que está ligado a outra possibilidade de tradução do prefixo grego para como "ao lado de", que permite pensar também numa intimidade, num acordo entre os textos (ANDRADE, 2010b, p. 258).

Se Barratt não chegou a pensar a possibilidade de a paródia significar uma intimidade, acordo entre os textos, ele foi capaz de perceber esse movimento em $O$ Mestre e Margarida e explicá-lo a partir dos instrumentos teóricos que tinha à mão. Não importa tanto aqui afirmar uma noção de paródia sobre a outra, mas perceber como mesmo uma análise que pensa a paródia apenas como "contracanto" precisou perceber que a inversão só se dava em um plano, mas não em outro.

Haroldo de Campos sugere, em 1981, uma "outra possibilidade para a tradução do prefixo grego para" ${ }^{37}$ (CAMPOS, 2005, p. 73). É Bakhtin quem está por trás dessa sugestão e que terá lugar central para a interpretação de Fausto por Haroldo de Campos. Deus e o Diabo

\footnotetext{
37 “Utilizei este conceito etimológico de paródia (do gr. pará, junto, ao lado de; óde, ode, canto) em minha introdução crítica (1966) a Oswald de Andrade - Trechos escolhidos, R. Janeiro, Agir, 'Nossos Clássicos', 1967. Escrevi então: 'Um dos principais recursos, no Miramar, é a paródia (da qual se valeram também Joyce e Thomas Mann, as duas grandes admirações de Oswald de Andrade no romance moderno). Paródia que não deve ser necessariamente entendida no sentido de imitação burlesca, mas inclusive na sua acepção etimológica de canto paralelo'." (CAMPOS, 2005, p. 73).
} 
no "Fausto" de Goethe (CAMPOS, 2005) tem um lugar chave aqui porque põe em diálogo promissor a obra de Goethe e o ambiente cultural soviético de 1920 e 1930.

Trata-se de uma noção de paródia muito próxima à de outros comentadores de $O$ Mestre e Margarida. Andrade (2010b, p. 259) aproxima o procedimento paródico de Bulgákov ao que Tiniánov chama de estilização (deixando de lado o que o próprio Bakhtin fala sobre estilização, ainda em outro sentido), a saber, a correspondência entre os planos do parodiado e do parodiante. E aproxima isso da sátira menipeia. Já Weir também vê a paródia em Bulgákov de um modo complexo: "Parody, as I use the term, is a form of imitative citationality that does not necessarily seek to discredit the work it targets, but always engages the values present within that target”38 (WEIR, 2002, p. 26). Ele também aproxima a obra de Bulgákov de concepções sobre o romance de Bakhtin, embora não estruture sua análise numa possível relação mais complexa entre o teórico e o escritor, sem chamar o romance de sátira menipeia.

Do "movimento plagiotrópico da literatura", por Mefístófeles entoar uma canção de Shakespeare, à consideração da análise bakhtiniana da cena da mascarada carnavalesca na obra de Goethe, Haroldo de Campos (2005, p. 79) vê algo ainda mais radical do que o teórico russo: para ele, "no Fausto - já na Primeira Parte, muito antes, portanto, da explícita cena da mascarada no Palácio Imperial destacada por Bakhtin - o texto se deixa, de cabo a rabo, sacudir por um indisfarçável estremeção carnavalesco" (CAMPOS, 2005, p. 79). Em sua busca pelos momentos de ruptura do Fausto, a argumentação de Haroldo de Campos vê na carnavalização - talvez por vezes de modo exagerado - potencial para pensar o transformativo da obra de Goethe.

Com isso, questiona a diacronia pela sincronia, ou seja, deslocando ideias de seus lugares e textos de seus contextos, produz uma contraditória abertura que permite entrever a complexa trama da paródia em Goethe e Bulgákov. O uso da paródia por Bulgákov tem algo de mefistofélico, mas também de carnavalesco. Em Haroldo de Campos, o carnavalesco

\footnotetext{
38 "Paródia, tal como uso o termo, é uma forma de 'citacionalidade' imitativa que não necessariamente quer descreditar a obra parodiada, mas que sempre se envolve e se relaciona com os valores desta." (Tradução nossa). E na nota relativa a essa frase: "like many other critical terms, 'parody' can be construed to mean many things. I am less interested in fixing the meaning of the term once and for all than I am in suggesting what it is not. I agree with Linda Hutcheon when she refuses to grant the parodying text absolute semantic authority over its target. [...] Thus parody, in the sense in which I am using it, does not force the reader to agree with the values of the parodying text and, indeed, may call upon the reader to suspect those values" (WEIR, 2002, p. 121). "Como muitos outros termos críticos, 'paródia' pode ser construída para significar muitas coisas. Estou menos interessado em determinar o sentido do termo de uma vez por todas do que em sugerir o que ele não é. Concordo com Linda Hutcheon quando ela se recusa a conceder ao texto que parodia autoridade semântica absoluta sobre o parodiado. [...] Assim, paródia, no sentido em que estou usando, não força o leitor a concordar com os valores do texto que parodia e, de fato, pode solicitar ao leitor suspeitar de tais valores." (Tradução nossa).
} 
transcende o mefistofélico, mas ambos também compartilham uma dupla precedência desde o ponto de vista da relação desses dois termos com Bulgákov: podemos arriscar que $O$ Mestre $e$ Margarida é carnavalesco porque mefistofélico, mefistofélico porque carnavalesco. Como Haroldo de Campos questiona a diacronia pela sincronia.

Além de ser um procedimento que permite uma recepção literária em literatura capaz de transpor criticamente tanto o tema quanto o plano das obras parodiadas para dentro da obra que parodia, essa noção de paródia mefisto-carnavalesca não inversiva pode ter consequências também para o problema moderno da relação entre arte e vida ao aproximar estética não de moral - como em Gógol e, em certo sentido, Dostoiévski ${ }^{39}$-, mas de ética (como sugerimos no primeiro capítulo).

Em "Arte e responsabilidade", de 1919, o problema de Bakhtin é como pensar uma responsabilidade do acontecimento: se no mais das vezes o humano se deixa levar pela mecanicidade externa de suas atividades, em uma aceitação irrefletida da normalidade do cotidiano, não há a mais profunda responsabilidade no atrevimento da arte de se distanciar do caráter corriqueiro da vida? É esta a questão de fundo quando ele afirma que "quando o homem está na arte não está na vida, e vice-versa” (BAKHTIN, 2015, p. XXXIII). Mas como pensar a relação entre esses dois âmbitos de modo consequente? Para Bakhtin, só há um nexo entre o tempo da criação e o tempo da "prosa do dia a dia" por meio da responsabilidade: eu devo responder com minha vida a fim de que seu "todo" não permaneça inativo. No entanto, essa responsabilidade à kantiana tem para Bakhtin seu correlato em uma culpa que é dupla: a arte tem culpa pela trivialidade da vida e o "homem da vida" pela "esterilidade" - pela não contaminação - da arte. A culpa da arte aparece não apenas porque ela não é capaz de contaminar completamente a vida de acontecimento, mas também por dar à vida o horizonte do acontecimento. Sem este, a normalidade não poderia nem ao menos almejar uma ruptura. Ao rompê-la, tem culpa o artista que não leva em conta o significado disso, usando, por exemplo, a desculpa da inspiração artística para justificar o descolamento de responsabilidade da arte em

\footnotetext{
${ }^{39}$ Grosso modo, pode-se dizer que a paródia tem função moralista em Almas mortas (1842) de Gógol - obra concebida para que fosse uma das partes da Divina Comédia russa -, ao expor os desvios de caráter do homem russo tendo como baliza os pecados capitais cristãos. É claro, no entanto, que é possível encontrar aspectos de crítica social no que Gógol chamou de poema. Em Crime e castigo (1866), Dostoiévski também dá ênfase a uma saída moral no âmbito da subjetividade humana e do comportamento individual ao explorar as consequências da ausência de deus como uma baliza do que é permitido fazer. Talvez seja o caso de ver Bulgákov promovendo uma virada ética - ao lado de Bakhtin, que quer ver o nexo entre arte e vida como responsabilidade ao apontar o caráter dialógico na obra de Dostoiévski. No comentário desta nota, partimos das análises que faremos no decorrer do texto. No último capítulo, analisaremos com mais vagar - embora evidentemente sem esgotar o tema - a possível diferença entre Bulgákov e Dostoiévski.
} 
relação à vida. Ao mesmo tempo, aqueles que trabalham em vistas da mecanicidade são culpados por fecharem a vida ao acontecimento da arte.

O jovem Bakhtin aponta que só uma responsabilidade radical pode responder a esse rasgo instaurado pela arte: agir na vida contando com a arte, criar respondendo pela vida. Essa resposta aparentemente razoável e concebível para sua época camufla o lugar incomum de Bakhtin, lugar da possibilidade de perceber o típico problema modernista da relação entre arte e vida em termos de responsabilidade do acontecimento.

Assim, por exemplo, o crítico e teórico inglês T. J. Clark lê esse breve texto percebendo esse lugar incomum de Bakhtin, mas tomando-o como pura expressão do horizonte de expectativas dos primeiros anos da década de 1920 soviética. Ao se perguntar sobre em que lugar El Lissitzki estaria no debate sobre "arte e responsabilidade" do período com seu "Propaganda em quadro na rua", sugere que ele estaria em uma posição radicalmente crua e contraditória em relação à responsabilidade, o que seria, em parte, uma repetição dos argumentos de Bakhtin: "Puts art on the streets. Not to be afraid to adopt the hectoring, acusatory tone of Trotsky's speech" ${ }^{40}$, mas, ao mesmo tempo, não ter "illusions about the enormity of the task" ${ }^{41}$, pois

any art that believed it could pose the question in less than apocalyptic terms was fooling itself utterly and dooming itself to the worst kind of failure - the failure of pretended praticality in a situation where practice (and value, and representation, and production, and all the vulgar prose of life) was precisely the category in doubt. ${ }^{42}$ (CLARK, 1999, p. 263).

Para Clark, esse lugar de El Lissitizki colocaria um fim ao estado de coisas modernista, ou seja, à dicotomia entre arte e vida. No entanto, para isso, é preciso que a noção de vida seja quebrada em duas. Por um lado, vida vira rua na aproximação que Clark faz de Bakhtin com El Lissitzki e Trotski. Por outro, vira a pretensa praticidade almejada pela arte propagandística. A complexidade do argumento de Clark aponta para a questão de como pensar a arte tomando a vida quando esta já está previamente tomada pelo tempo do acontecimento. Talvez com uma arte propagandística que finja praticidade. Ou seja, talvez levando à arte o aspecto da

\footnotetext{
40 "Colocar a arte nas ruas. Não ter medo de adotar o tom acusador, intimidador, do discurso de Trótski." (Tradução nossa).

41 “[...] Ilusões sobre a enormidade da tarefa." (Tradução nossa).

42 ، “....] Qualquer arte que acreditava poder colocar a questão em termos que não apocalípticos estava se enganando completamente e se condenando ao pior tipo de fracasso - o fracasso da pretensão de praticidade, em uma situação na qual precisamente a categoria de prática (e de valor, e de representação, e de produção, e de toda a prosa vulgar da vida) estava em questão." (Tradução nossa).
} 
praticidade da vida, tornando a arte prática. Mas o aspecto prático da vida que adentra a arte, nesse caso, faz desta uma propaganda. É claro, no entanto, que nem a Revolução pode ser tomada completamente como um acontecimento na vida, nem a arte de El Lissitzki havia sido completamente dominada pela vida prática, ou seja, havia se tornado propaganda. Assim, mesmo com a divisão da noção de vida em duas outras noções, ocorre tanto a manutenção da impossibilidade de redução da arte à vida e vice-versa em diversos níveis da contraposição entre elas, como também dos próprios termos da contraposição (arte e vida) que não são completamente renovados ou ressignificados, o que está de acordo com o que Bakhtin veicula em seu texto.

Não é por meio da aniquilação dos âmbitos de arte e vida que Bakhtin pode estar além do estado de coisas modernista, mas sim pela noção de responsabilidade. Contudo, aqui, a noção de responsabilidade foi compreendida de modo cru, como uma responsabilidade nem tanto revolucionária, mas já partidária, no sentido de uma apropriação a posteriori do acontecimento revolucionário por um determinado grupo político e artístico, quando se compreende o âmbito da vida a partir do lugar da propaganda. Aqui está a outra parte do argumento de Bakhtin que El Lissitzki não recupera: a propaganda artístico-política não instaura uma relação responsável entre o acontecimento da arte e a vida, mas procura apropriar-se (ou tomar posse) do acontecimento que tomou a vida por meio da normalização da arte. Ao fazer isso, reinstaura uma relação de poder que não pode ser de modo algum denominada de responsável. E, com isso, tanto a noção de arte como a de responsabilidade como tal, presentes no texto de Bakhtin, perdem o incomum de seu lugar.

Talvez o que está em jogo aqui seja a multivocidade dos termos. O próprio Bakhtin, em outro texto ainda da década de 1920, “O problema do conteúdo, do material, e da forma na estética literária" (1924), apesar de ainda adotar certa retórica positivista, sistematiza uma crítica teórica filosófica à teoria formalista da literatura, na qual repõe a questão de outro modo, aproveitando-se dessa multivocidade dos termos da dicotomia.

Nesse texto, sua acusação principal aos "novos" teóricos da literatura ${ }^{43}$ de seu país refere-se ao fato de que eles não seriam capazes de pensar filosoficamente o problema que se

\footnotetext{
${ }^{43}$ Nossa intenção, aqui, não é a de tratar da disputa mesmo entre Bakhtin e os formalistas, mas sim a de reconstruir os argumentos de Bakhtin em vista do problema da responsabilidade colocado por ele em seu primeiro texto. Não se trata, portanto, de tomada de posição por Bakhtin, mas de um estudo crítico de seus argumentos. Por isso, acabamos deixando de lado a possível resposta formalista a Bakhtin. Além disso, para alguma noção do contexto em que essa disputa se deu e o lugar de Bakhtin nas inúmeras críticas que foram feitas aos formalistas no período, ver (CLARK, K., HOLQUIST, M., 2014, p. 186-196): "The widespread reaction against Formalism broke down into a right and a left wing. The right wing was made up of all those who based their objections on one or another of the traditional schools of criticism, such as those biographical or historical approaches that had been taught in
} 
colocaram. Ao analisarem somente a forma e o material, bem como ao tentarem compreender a literatura desde o ponto de vista da ciência natural ou da linguística, eles deixam de lado o problema da relação da forma e do material com o conteúdo, o mundo, a realidade e os valores éticos.

É claro que uma abordagem da literatura que só lide com o conteúdo não pode ser chamada de científica para Bakhtin, mas a abordagem formal que abre mão de pensar a unidade entre forma e conteúdo, entre arte e vida, está abdicando de problematizar filosoficamente a fundo a questão que eles mesmos se colocaram e, com isso, é falha:

[...] o desejo de construir uma ciência a todo custo e o mais rápido possível sempre acarreta uma grande queda do nível da problemática, um empobrecimento do objetivo submetido a estudo, e até a substituição desse objeto (no nosso caso, da obra de arte literária) por outra coisa bem diferente. [...] Construir uma ciência sobre este ou aquele domínio da criação cultural, mantendo toda a complexidade, plenitude e originalidade do objeto, é um trabalho extremamente difícil. (BAKHTIN, 2010, p. 10).

A reivindicação de Bakhtin em relação aos formalistas, então, não é tanto a de não perceberem o fundamento de sua escola na estética romântica alemã - tal como sugere Todorov $^{44}-$, ou talvez sim, mas apenas na medida em que isso signifique que o problema está

the university before the Revolution. The most powerful arguments from the right were mounted less by literary critics than by philosophers, such as Gustav Spet or Alexander Smirnov, or by those who were thoroughly at home in philosophy. Bakhtin had a certain affinity with this camp, if only because he fully subscribed to its charge that the Formalists' ingenious interpretations of particular works lacked a theoretical base in a full-blown aesthetics. This was the characteristic charge of the Formalists' right-wing opponents. The attack from the left, chiefly mounted by such eminent Marxists as Trotsky and such representatives of sociological criticism as P. N. Sakulin, maintained that the Formalists ignored social and political factors in their work. Although Bakhtin shared many of these left-wing reservations as well about the Formalists, the philosophical poverty behind their methodological practice is chiefly what occupies him in 'The Problem of Content'" (CLARK, K., HOLQUIST, M., 2014, p. 1889) . "A ampla reação contra o formalismo quebrou-se em uma ala esquerda e em uma direita. A ala direita era composta de todos aqueles que baseavam suas objeções em uma ou outra das escolas tradicionais da crítica, tais como aquelas abordagens históricas ou biográficas que eram ensinadas na universidade antes da Revolução. O argumento mais potente da direita provinha menos de críticos literários do que de filósofos, tais como Gustav Spet ou Alexandre Smirnov, ou ainda por aqueles que se sentiam completamente em casa na filosofia. Bakhtin tinha certa afinidade com este campo, no mínimo porque ele subscrevia completamente à sua acusação de que as interpretações ingênuas dos Formalistas de obras particulares careciam de uma base teórica estética desenvolvida de modo completo. Essa era a acusação característica contra os formalistas oriunda de seus oponentes da ala direita. $\mathrm{O}$ ataque da esquerda, perpetrada principalmente por marxistas eminentes como Trótski e representantes da crítica sociológica, tal como P. N. Sakulin, sustentava que os formalistas ignoravam fatores sociais e políticos em suas obras. Embora Bakhtin também compartilhasse de muitas dessas reservas da ala esquerda sobre os formalistas, a pobreza filosófica por trás da prática metodológica dos formalistas fora o que completamente o ocupara em ' $\mathrm{O}$ problema do conteúdo'." (Tradução nossa). Em relação a esta longa citação, o que estamos tentando explorar é em que medida, para Bakhtin, criticar a pobreza filosófica dos formalistas é igualmente criticar a falta de elementos sociais e políticos - éticos - em seus trabalhos, ou seja, em que medida há uma inseparabilidade dessa crítica, que é o que faz de sua posição e de sua crítica aos formalistas extremamente atual.

${ }^{44}$ Ver: (TODOROV, 2015, p. XVII): "Portanto, Bakhtin não critica a própria oposição entre arte e não arte, entre poesia e discurso cotidiano, mas o ponto onde os formalistas procuram situá-la. [...] A crítica de Bakhtin incide, 
em erigir uma teoria de modo (contraditoriamente) filosoficamente ingênuo, uma teoria que não seja capaz de levar às últimas consequências seus pressupostos:

A posição científica desses trabalhos não é satisfatória porque, afinal de contas, ela é condicionada por uma atitude incorreta ou, na melhor das hipóteses, metodicamente imprecisa, da poética por eles elaborada para com a estética sistemático-filosófica geral.

[...]Não se pode superar a discordância metodológica no campo do estudo da arte por meio da criação de um novo método - um a mais a tomar parte no conflito geral dos métodos, que exploraria somente a seu modo o caráter fatual da arte - mas sim, por meio da argumentação sistemático-filosófica do fato e da singularidade da arte na unidade da cultura. (BAKHTIN, 2010, p. 14).

Com uma retórica cientificista que posteriormente irá abandonar, porque contradiz sua própria reivindicação, o ainda jovem Bakhtin não está interessado em fundamentar filosoficamente o formalismo ou em alargá-lo, mas sim em pensar mesmo algo radical que já estava indicado naquele seu primeiro texto: a unidade, o nexo entre arte e vida, entre forma material e conteúdo ético. Esse nexo agora aparece como perfazendo uma unidade na cultura. Trata-se de pensar filosoficamente, então, o papel que apenas a arte é capaz de exercer no campo da cultura, e não simplesmente de criar uma nova vertente para se somar às muitas já existentes.

Com sua reivindicação, põe-se em um lugar complexo e crítico: em sua discordância em relação ao formalismo, não se trata, portanto, de uma crítica superficial ao seu materialismo, mas sim de uma condenação do próprio desejo de criação de uma nova escola ou "método" por si mesmo, uma criação que, filosoficamente ingênua, não é capaz de ir além da superfície dos problemas filosóficos já contidos nas escolas já em disputa.

Mesmo assim, ainda seria possível parecer que Bakhtin propõe uma extensão do formalismo que segundo ele só seria capaz de realizar bem a segunda tarefa; entretanto, seria preciso uma verdadeira reviravolta na "estética material" para que ela atendesse às reivindicações bakhtinianas preocupadas com o nexo entre arte e vida, agora entendido também como nexo entre forma e conteúdo (valor, ética). É por isso que, para ele, é importante postular, entre outras coisas, a diferença entre as formas arquitetônicas e composicionais - entre forma

portanto, sobre os formalistas, mas não sobre o âmbito da estética romântica de que são oriundos. O que ele lhes censura não é seu 'formalismo', e sim seu 'materialismo'; poderíamos até dizer que Bakhtin é mais formalista do que eles, se tornarmos a dar à 'forma' seu sentido pleno de interação e de unidade dos diferentes elementos da obra (sentido que também não está totalmente ausente entre os formalistas); é esse outro sentido que Bakhtin tenta reencontrar, introduzindo estes sinônimos valorizados: 'arquitetônica' ou 'construção"'. Como podemos ver, para Todorov, Bakhtin está meramente contrapondo uma posição filosófica por outra - é claro que, no limite, Bakhtin chegará a uma posição filosófica; mas mais do que tudo, sua posição ainda mais radical é a de reivindicar que qualquer posicionamento filosófico tomado - seja 'formalista', seja 'materialista', ou qualquer outro - implica problemas filosóficos que devem ser enfrentados, e não normatizados e deixados de lado. 
do conteúdo e forma do material -, bem como exigir que se devesse, mesmo que não fosse seu objeto principal de análise, ao menos ter em vista a experiência estética fora da arte. Com isso, o problema do formalismo é ainda mais profundo, e atinge a interioridade de seu método: ele, além do mais, também não é capaz de compreender como o próprio material atua no interior da obra:

A estética material não pode estabelecer a diferença essencial entre o objeto estético e a obra exterior, entre a articulação e as ligações no interior deste objeto e as articulações e ligações materiais no interior da obra; por toda parte ela mostra uma tendência de misturar estes elementos. (BAKHTIN, 2010, p. 21).

Os formalistas então não dão conta nem da arte que adentra a vida, nem - o que é mais problemático para uma teoria estética - da vida ou conteúdo que adentra a arte.

Assim, não se trata de recusar a análise da forma e do material em nome da análise do conteúdo, muito menos de fundamentar um novo método de análise literária a partir do momento do conteúdo; mas sim de reivindicar justamente que não se opere uma redução filosoficamente ingênua do problema complexo da relação desses três momentos da obra de arte.

É nesse sentido que Bakhtin irá forjar o conceito de objeto estético para pensar a obra de arte desde o ponto de vista singular da estética. O objeto estético é "o conteúdo da atividade estética" e, como tal, um objeto material, claro, mas que não se reduz a este seu aspecto: ele é "uma totalidade de valores expressa pela forma material quando combinada com outros valores, como o político e o religioso" (CLARK, K., HOLQUIST, M., 2014, p. 189). Ele é a obra de arte que se apresenta para nós desde uma observação de seu conteúdo, sendo assim diferente da obra de arte vista a partir da forma e da matéria, mas que, ao mesmo tempo, é determinada por forma e matéria, assim como forma e matéria o são uma pela outra e pelo conteúdo.

E é por isso que uma análise estética tem como tarefa todas essas três visadas: 1. a que se ocupa com o que ele chama de estrutura arquitetônica da obra, que é a que vê a obra enquanto objeto estético, preocupada em compreendê-la desde um ponto de vista artístico-contemplativo. As outras duas são: 2. a compreensão da estrutura da forma, totalmente independente do objeto estético propriamente dito, como o fenômeno da língua; e 3. a obra exterior, o material, nome que ele dá para o método teleológico de organização composicional do material.

Bakhtin deixa claro em diversas passagens que não diferenciar esses três momentos da tarefa da análise estética é o déficit da estética materialista, a qual, ao fazer isso, acaba 
confundindo a análise do material com a análise do objeto estético propriamente dito, mais por conta da virtude do próprio pesquisador do que do método que por si só restringiria a análise a uma positivação científica da obra de arte:

Estritamente falando, a estética material só tem acesso total à segunda das tarefas de análise estética indicadas por nós, que é, em suma, o estudo ainda não estético da natureza da obra, como objeto das ciências naturais ou da linguística. Ela não pode realizar satisfatoriamente a análise da obra como conjunto composicional com fim definido, em virtude da ausência da compreensão da singularidade do objeto estético. Naturalmente, esse objeto provém da contemplação estética viva do pesquisador, mas sem nenhuma análise crítica nem tomada de consciência metódica. (BAKHTIN, 2010, p. 23).

Ao confundirem o que Bakhtin chama de formas arquitetônicas e formas composicionais, ou seja, ao confundirem a análise da forma do conteúdo com a análise da forma do material, os formalistas misturam a forma da obra, como aquilo que Bakhtin chama de individualização estética da obra, com a forma da obra como material organizado, ou seja, como entidade teleológica composicional. Em outras palavras: analisar a forma da obra a partir de seu material nos faz compreendê-la como uma coisa feita segundo determinados fins e que cabe ao seu interprete percebê-los; mas haveria um outro momento da análise - e é esse que Bakhtin está reivindicando aqui -, que analisa o próprio conteúdo da obra de arte como sentimentos, valores morais e físicos, "acontecimentos nos seus aspectos de vida particular, social, histórica" (BAKHTIN, 2010, p. 24). O problema de não levar esse momento da análise do conteúdo em conta é que, no limite, esse método não é capaz de perceber a relação de uma estética específica, como a literária, com a visão estética fora da arte e com a estética geral, pois

as formas arquitetônicas principais são comuns a todas as artes e a todo o domínio da estética, elas constituem a unidade desse domínio. Entre as formas composicionais das diferentes artes existem analogias determinadas pela comunidade das tarefas arquitetônicas, mas é aqui que as particularidades dos materiais assumem seus direitos. (BAKHTIN, 2010, p. 26).

E é aí que está o centro da crítica bakhtiniana à abordagem, por exemplo, da história da literatura dos formalistas: o problema não é colocado como uma contraposição entre diacronia e sincronia históricas, ou até é, mas apenas na medida em que a sincronia significa um esgarçamento do horizonte histórico do método materialista, na medida em que se restringe a pensar a evolução apenas de uma arte, a literária, e apenas do ponto de vista de sua técnica. Deixando de lado o conteúdo que transcende a forma literária em inúmeras manifestações 
culturais, os formalistas perdem a própria possibilidade de pensar a história da literatura propriamente dita como a história da relação do conteúdo com a forma, que é a história particular da literatura em relação ao todo da cultura.

Entre outros motivos, é então porque a história da literatura ficaria em si mesma mal compreendida que ele enfaticamente ressalta como é indispensável pensar essa arte específica em sua relação com a estética geral. Isso mesmo reconhecendo que não é possível nem basear uma estética literária a partir do esteticismo que encontra uma experiência estética não na arte, mas na vida, nem pensar a história da literatura sem uma elaboração estética desta mesma arte. No entanto, é indispensável, mesmo assim, não abrir mão desse momento de transcendência do campo estético específico porque apenas a estética geral "vê e fundamenta a arte na sua interdependência e interação essenciais com todos os outros campos da criação cultural, na unidade da cultura e na unidade do processo histórico da sua transformação" (BAKHTIN, 2010, p. 26). Ao se limitar à forma composicional, a estética material pode, no melhor dos casos, perceber "apenas" a evolução sincrônica de determinada técnica de uma arte dada, mas isso de modo algum pode ser visto como dotado de história:

\footnotetext{
A estética material que isola na cultura não só a arte, mas também as artes particulares, e que toma a obra não em sua vida artística, mas como uma coisa, um material organizado, é capaz, no melhor dos casos de estabelecer apenas o quadro cronológico das modificações dos processos técnicos da arte dada, pois uma técnica isolada não pode absolutamente ter história. (BAKHTIN, 2010, p. 27).
}

O que Bakhtin quer demonstrar é que o déficit de reflexão filosófica da estética materialista leva não apenas a dificuldades em seu próprio interior, como no conceito de forma, mas que também tem como consequência problemas na sua concepção de história da literatura: só com essa exigência de complexificação teórica do escopo de uma estética literária particular que uma tal estética literária pode ocorrer; igualmente, só uma história da literatura que leve em conta uma ampliação do horizonte histórico pode dar conta da história da literatura como tal.

As consequências das diferenças de concepção histórica de Bakhtin e dos formalistas ficam extremamente evidentes justamente nos estudos sobre a paródia e o cômico através da análise das obras de Dostoiévski (e outros). Enquanto Tiniánov em "Dostoiévski e Gógol (para uma teoria da paródia)", de 1921, restringe o campo de estudos à literatura de língua russa de um determinado período, pensando a evolução literária em termos quase de uma evolução darwinista de erros e acertos, Bakhtin, em contrapartida, em seu estudo da poética de 
Dostoiévski, de 1929, está pensando sua singularidade dentro do desenvolvimento da cultura carnavalesca desde a Antiguidade, na evolução e percurso do diálogo socrático e da sátira menipeia como gêneros em que ocorre a evolução histórica do dialogismo:

\begin{abstract}
Ocorre que a combinação do caráter aventuresco com a aguda problematicidade, o caráter dialógico, a confissão, a vida e a pregação não era, em hipótese alguma algo absolutamente novo e inédito. Novo era apenas o emprego polifônico e a assimilação dessa combinação dos gêneros por Dostoiévski. A combinação propriamente dita tem suas raízes na remota Antiguidade. O romance de aventuras do século XIX é apenas um ramo [...] da poderosa e amplamente ramificada tradição do gênero [...]. Consideramos necessário estudar essa tradição precisamente até as suas fontes. [...] Essa digressão histórica nos ajudará a entender de modo mais profundo e mais correto as peculiaridades do gênero, do enredo e da composição das obras de Dostoiévski [...]. Além disso, achamos que essa questão tem importância mais ampla para a teoria e a história dos gêneros literários. (BAKHTIN, 2013, p.120-1, grifo nosso).
\end{abstract}

É nesse sentido que Bakhtin afirma que "para entrar na História" com H maiúsculo "é preciso deixar de ser apenas si próprio" (BAKHTIN, 2010, p. 27). Essa afirmação, que reivindica a história como algo dialético, leva Bakhtin a defender que só é possível pensar diacronicamente a história da literatura a partir do que hoje chamaríamos de multidisciplinaridade: só um estudo multidisciplinar que levasse em conta o todo da cultura seria capaz de entrar na história, já que colocaria em jogo a relação de determinados conteúdos - objetos estéticos - com variadas formas materiais de apreensão desse conteúdo.

Ao fazer isso, a prosa de Dostoiévski é contraposta a um outro que é ele mesmo, ou ele mesmo é um outro novo, atual e renovado desse outro:

Por sua natureza mesma, o gênero literário reflete as tendências mais estáveis, "perenes" da evolução da literatura. O gênero sempre conserva os elementos imorredouros da archaica. É verdade que nele essa archaica só se conserva graças à sua permanente renovação, vale dizer, graças à atualização. $\mathrm{O}$ gênero sempre é e não é o mesmo, sempre é novo e velho ao mesmo tempo. O gênero renasce e se renova em cada nova etapa do desenvolvimento da literatura e em cada obra individual de um dado gênero. Nisso consiste a vida do gênero. Por isso, não é morta nem a archaica que se conserva no gênero; ela é eternamente viva, ou seja, é uma archaica com capacidade de renovar-se. O gênero vive do presente, mas sempre recorda o seu passado, o seu começo. É o representante da memória criativa no processo de desenvolvimento literário. É precisamente por isso que tem a capacidade de assegurar a unidade e a continuidade desse desenvolvimento. (BAKHTIN, 2013, p. 121).

É esse arcabouço histórico, ou melhor, essa visada particular da história da literatura que podemos compreender ao percorrer alguns dos principais momentos do pensamento de 
Bakhtin, que faz com que a sua noção de sátira menipeia se diferencie substancialmente das noções de paródia e de estilização de Tiniánov. O próprio nome "menipeia" já revela essa preocupação com o lado histórico e cultural do procedimento satírico de Dostoiévski, preocupação da qual Tiniánov passa ao largo e que tem como fundo o problema da responsabilidade como nexo entre arte e vida.

Mas é justamente em relação a esse problema da responsabilidade colocado desta forma que Bakhtin mais gera polêmica: ronda a figura de Bakhtin certa ideia de que, por teorizar a comicidade e o riso, seria estranho a ele a reivindicação de responsabilidade do acontecimento. A questão aqui é pelos limites do acontecimento cômico: seria ele capaz de instaurar, de fato, um nexo entre arte e vida? ${ }^{45}$

Para Safatle, no texto "Sobre o riso que não reconcilia: Notas a respeito da 'Ideologia da ironização"” (2008), não: tal acontecimento não é capaz de romper "a forma ingênua, o mais das vezes mecânica" (BAKHTIN, 2015, p. XXXIII) com que o artista e o homem estão unificados. Concebendo a multivocidade das noções de arte e vida a partir da dicotomia Lei/anomia (normatividade sócio-político-jurídica/caráter subversivo), Safatle defende que a teoria da cultura carnavalesca de Bakhtin perpetua o establishment, porque pensada a partir de festas populares da Idade Média que não seriam capazes de romper com o status quo ao suspenderem o domínio da Lei:

Se a relação fosse realmente de oposição, seria difícil explicar como o ordenamento jurídico é capaz de se reconfigurar imediatamente após o período de anomia, sem que tal período implique em necessidade de reorientação dos processos de normatização. Ou seja, eles retornam tal como eram antes. Assim, para além da tentativa bakhtiniana de entificação de um certo caráter subversivo do riso popular que teria no carnaval seu espaço social privilegiado, riso popular que seria uma das raízes do cinismo grego, devemos insistir na complementaridade entre posição da norma e sua ironização paródica (SAFATLE, 2008, p. 8).

\footnotetext{
${ }^{45}$ Vale ressaltar que não é fortuita a busca por aproximar o que Clark e Holquist chamam de "a arquitetura da responsabilidade" de Bakhtin (a série de textos da primeira fase de Bakhtin na qual ele de diversos modos está pensando o problema da responsabilidade) com seus estudos sobre Dostoiévski: "With the exception of The Architectonics of Answerability, this book [Problemas da poética de Dostoiévski] absorbed Bakhtin's attention for a longer time than any other work" (CLARK, K., HOLQUIST, M., 2014, p. 239) ("Com exceção da Arquitetônica da responsabilidade, esse livro absorveu a atenção de Bakhtin por um período mais longo do que qualquer outra obra"; ou ainda: "Dostoevsky's polyphony illustrates the concept of autorship that Bakhtin had proposed at a more abstract level in 1919 in The Architectonics and again in 1924 in "The Problem of Content, Material, and Form in the Verbal Work of Art” (CLARK, HOLQUIST, M., 2014, p. 242) ("A polifonia de Dostoiévski ilustra a concepção de autoria que Bakhtin propôs em um nível mais abstrato em 1919, nas Arquitetônicas, e novamente em 1924, em 'O problema do conteúdo, do material e da forma na obra de arte verbal"”). (Traduções nossas).
} 
É digno de nota que há ao menos uma possibilidade de defender o caráter subversivo da teoria bakhtiniana concordando com a ideia de Safatle de que a ironização paródica do carnaval seria complementar à "posição da norma": trata-se de distinguir entre carnaval e teoria da carnavalização. Com isso, seria possível entender esta como uma tentativa de pensar a cultura oficial stalinista não como seu contraponto, mas como a sua definição que a desmascara. É isso que sugere Groys a seguir:

[...] Se se encontra no "monologismo" de Bakhtin, igualmente e com razão, uma metáfora para a cultura stalinista oficial, o carnaval não é, contudo, nenhuma "alternativa democrática" àquela, conquanto seu lado irracional e destrutivo. A descrição de Bakhtin do carnaval lembra acima de tudo a atmosfera dos processos espetaculosos stalinistas com seus incríveis "coroamentos e destronamentos". (GROYS, 2009, p. 223).

Aqui, trata-se de pensar o carnaval enquanto período de anomia complementar à Lei em um momento em que essa dicotomia foi invertida: a própria lei contém em si a suspensão carnavalesca de si mesma. Nesse caso, seria possível considerar que a teoria de Bakhtin está pensando o nexo entre arte e vida a partir da categoria de responsabilidade, acusando "a atmosfera dos processos espetaculosos stalinistas", ela sim, de irresponsável, porque carnavalesca.

Mas outra possibilidade de defender o caráter subversivo da posição bakhtiniana subversivo enquanto modo de entender a responsabilidade como nexo entre arte e vida (como foi possível a T. J. Clark ver uma resposta ao debate da relação entre arte e responsabilidade no fato de El Lissitzki levar a arte à rua) - é pensar que, em alguns casos, é responsável reivindicar certa irresponsabilidade, que nesses casos há um dever de irresponsabilidade. É Derrida quem reflete sobre a responsabilidade que envolve a literatura que tem como pressuposto a licença dada "ao escritor para dizer tudo o que queira ou tudo o que possa, permanecendo, ao mesmo tempo, protegido de toda censura, seja religiosa ou política" (DERRIDA, 2014, p. 52):

A liberdade de dizer tudo é uma arma política muito poderosa, mas pode imediatamente se deixar neutralizar como ficção. Esse poder revolucionário pode tornar-se muito conservador. $\mathrm{O}$ escritor pode, igualmente de fato ser considerado irresponsável. Ele pode, eu diria até que deve, às vezes, reivindicar certa irresponsabilidade, pelo menos no tocante a poderes ideológicos, de tipo zhdanoviano, por exemplo, que tentam cobrar dele responsabilidades extremamente determinadas perante os órgãos sociopolíticos e ideológicos. Esse dever de irresponsabilidade, de se recusar a responder por seu pensamento ou por sua escritura diante de poderes constituídos, talvez seja a forma mais elevada de responsabilidade. (DERRIDA, 2014, p. 53). 
É possível então pensar que determinados casos exigem uma responsabilidade irresponsável e que o carnaval, tal como pensado por Bakhtin, pode ser um deles. O próprio ambiente cultural soviético das décadas de 1920 e 1930 em que Bakhtin desenvolve seu pensamento pode ser outro desses casos, mas agora não como uma teoria capaz de corroer o poder soviético ao evidenciar seu monologismo dialógico, mas sim como uma capaz de corroêlo ao evidenciar as estruturas da relação promíscua entre discurso, verdade e poder.

Tal contextualização segundo os casos de seu uso é o que Safatle não faz, já que está pensando a retomada do cinismo ${ }^{46}$ no capitalismo pós-moderno através de Bakhtin, passando ao largo do contexto sociopolítico da escrita de Bakhtin. Sem esse esforço de entender sincronicamente Bakhtin, pode acontecer que sua força diacrônica seja mal compreendida. Diferentemente de meramente dar prazer ao governante que tende à tirania ${ }^{47}$ que não instauraria uma quebra entre tempo da arte e tempo da vida, nem muito menos um nexo de responsabilidade entre eles, trata-se aqui de entrever através da contextualização da carnavalização de Bakhtin tanto internamente ao pensamento bakhtiniano em relação ao seu percurso teórico (a evolução de sua produção), quanto externamente em relação ao contexto da cultura soviética dos anos de 1920 e 1930 - a possibilidade de haver uma responsabilidade complexa no riso cínico. Tratase de uma responsabilidade que valoriza a separação dos âmbitos da vida e da arte como um modo de rejeitar uma redução de uma pela outra, funcionando essa valorização desse dualismo paradoxalmente como um modo de se resguardar contra o pensamento dual de uma luta entre "um contra outro" e de estar a favor do próprio espaço da luta entre vários.

Assim, é como se Safatle identificasse no rompimento das categorias de arte e vida a subversão autêntica, sem perceber que Bakhtin está apostando no fortalecimento da contraposição, pensando a subversão como o modo responsável de ligação entre essas duas categorias. Então, não haveria problema se, após o período de anomia do baile carnavalesco, a Lei voltasse a imperar, porque não é a arte que se contrapõe internamente à Lei: ela apenas a compreende e a expõe e caberia então aos homens da vida agirem à altura do desvelamento da

\footnotetext{
${ }^{46}$ Safatle tem razão em ver Bakhtin no centro da discussão sobre o cinismo, mas ao não tomar o devido cuidado teórico e contextual, acaba mais apontando as dificuldades de possíveis interpretações de Bakhtin que não dão conta de pensar a responsabilidade, do que as dificuldades do próprio pensamento bakhtiniano. Preocupado que está em apontar o potencial conservador de certo cinismo contemporâneo, pensa este como coadunando com o poder ao se voltar contra o discurso crítico, não tendo olhos para enxergar a complexidade de um pensamento que se volta, ao mesmo tempo, contra as falhas de ambos, na busca por uma resposta mais radicalmente responsável.

${ }^{47}$ Epígrafe do artigo de Safatle: "Celui qui plaisante à la tête du governement tend à la tyrannie. Saint-Just" (SAFATLE, 2008, p. 1) (“Aquele que dá prazer à cabeça do governante tende à tirania.”). (Tradução nossa)
} 
arte para a modificação do establishment. Problemático seria a arte tomar para si esse papel, pois aí sim, então, poderíamos nos deparar com a maior das tiranias. A teoria do carnaval de Bakhtin não é uma teoria social, mas sim uma teoria do nexo entre arte e sociedade, entre arte e vida, e por isso pode buscar conservar esses dois polos sem ser com isso política e socialmente conservadora.

Sem levar em conta o estudo de Bakhtin sobre Dostoiévski, a única vez em que Safatle usa o termo sátira em seu artigo não é a partir de Bakhtin, mas de Adorno, e é justamente a ideia de sátira menipeia que nos pode ajudar a pensar essa responsabilidade radical e complexa de Bakhtin que estamos investigando. Para Safatle, que retoma a análise de Adorno da sátira em Juvenal na Mínima Moralia (1947), a sátira ocorre apenas como crítica da decadência dos costumes e, portanto, servindo à "lógica da conservação":

No parágrafo de Adorno, a ironia, em especial aquela que aparece sob a forma da sátira, é compreendida como reação do poder aos imperativos de mudança, isto devido ao alvo privilegiado da sátira ser normalmente a 'decadência dos costumes'. A crítica que se serve da ironia seria vinculada à lógica da conservação porque seu critério de orientação: "é sempre o critério ameaçado pelo progresso"; este permanece pressuposto como ideologia imperante, a tal ponto que o fenômeno que foge à regra é rejeitado, sem que lhe faça a justiça de uma discussão racional. Ela se orienta assim através de um "acordo transcendental imanente", de um common sense nunca colocado em causa. (SAFATLE, 2008, p. 3-4).

Safatle não analisa então as características da sátira menipeia expostas por Bakhtin, e que poderiam levá-lo a perceber a radicalidade da posição do autor russo em relação à responsabilidade. Além disso, opera uma dicotomia entre seriedade e comicidade que o impede de ver qualquer potencial emancipador no cômico ${ }^{48}$. Entre as muitas características desse gênero, Bakhtin reivindica à sátira menipeia a capacidade de experimentar as últimas posições filosóficas, colocando em dúvida tanto os pressupostos de seu próprio discurso como os do discurso filosófico-ideológico. Ao fazer isso, tal sátira não visa conservar o common sense, mas estar numa posição difícil, a de desvelar, ao mesmo tempo, os dois tipos de discurso: o do common sense e o do discurso dito profundo, mostrando como mesmo o segundo teria algo ainda que conservar frente ao satírico. Ela é capaz de levar a cabo esse duplo desvelamento porque sua forma explicita as estruturas discursivas e narrativas do discurso através, por exemplo, do recurso ao fantástico. Como já vimos,

\footnotetext{
${ }^{48}$ É interessante observar que mesmo operando uma dicotomia aqui, o próprio Safatle é crítico das dicotomias simplificadoras em outros textos.
} 
a ousadia da invenção e do fantástico combina-se na menipeia com um excepcional universalismo filosófico e uma extrema capacidade de ver o mundo. A menipeia é o gênero das "últimas questões", onde se experimentam as últimas posições filosóficas. (BAKHTIN, 2013, p. 131).

Sem levar isso em conta, parece que filosofia e sátira não combinam, como se só houvesse um único gênero filosófico por excelência. Em contrapartida, buscamos reivindicar a possibilidade de que a filosofia - enquanto quebra da mecanicidade da vida e abertura ao questionamento como acontecimento - não pertence a um gênero discursivo específico, mas pode se combinar com vários, assumindo a cada vez aspectos diferentes sem nunca deixar de lado tal característica desmecanizadora. E, nesse sentido, a sátira menipeia é capaz de colocar em questão a própria mecanicidade desse processo de abertura ao filosófico:

A carnavalização também penetra no profundo núcleo filosófico dialógico da
menipeia. Vimos que esse gênero se caracteriza por uma colocação manifesta
das últimas questões da vida e da morte e por uma extrema universalidade (ele
desconhece os problemas particulares e a argumentação filosófica ampla). O
pensamento carnavalesco também se faz presente no campo das últimas
questões, não apresentando para estas, porém, nítida solução filosófica
abstrata ou dogmático-religiosa, mas interpretando-as na forma concreto-
sensorial das ações e imagens carnavalescas. Por isso a carnavalização
permitiu, através da cosmovisão carnavalesca, transferir as últimas questões,
do plano filosófico abstrato para o plano concreto-sensorial das imagens e
acontecimentos carnavalescamente dinâmicos, diversos e vivos. Foi a
cosmovisão carnavalesca que permitiu "pôr na filosofia as vestes multicores
da hetera". A cosmovisão carnavalesca era a correia de transmissão entre a
ideia e a imagem artística da aventura. Na literatura europeia dos tempos
modernos, encontramos um claro exemplo disso nas novelas filosóficas de
Voltaire, com seu universalismo filosófico e a dinâmica e policromia
carnavalesca (Cândido, por exemplo). Essas novelas mostram em forma muito
patente, as tradições da menipeia e da carnavalização. Desse modo, a
carnavalização penetra até mesmo no núcleo propriamente filosófico da
menipeia. (BAKHTIN, 2013, p. 153).

Em O Mestre e Margarida é justamente o elemento fantástico - a aparição de Woland, o diabo fáustico, na Moscou soviética - que expõe os alicerces da estrutura do discurso ideológico oficial em alguns de seus pontos mais sensíveis, como a construção do homem soviético, o cientificismo, o didatismo, a imprensa, o problema da moradia etc. A presença do poder diabólico, simultaneamente extra-humano e fantástico, ao mesmo tempo se contrapõe ao poder humano oficial, revelando sua fraqueza frente à potência demoníaca, e a imita parodicamente, expondo os mecanismos de consolidação das redes discursivas que sustentam o poder soviético. Nesse sentido, Woland é a verdade do poder soviético como paródia. 
Mas há outro nível paródico da prosa de Bulgákov que não é o de meramente inverter o (único) texto base parodiado. Em primeiro lugar, nesse outro nível a paródia tem como base uma multiplicidade de escrituras. Em segundo, ela se amplia, cantando junto delas. Woland é paródia (entre outros) do Mefistófeles goethiano; contudo, a lógica da relação entre um e outro não é a de uma dualidade presente na palavra "inversão", mas a de multiplicidades complexas que se conectam e se desconectam, que se aproximam e se afastam. Nesse jogo complexo de relações múltiplas - em que outros textos bases também se relacionam em sua composição -, ocorre uma abertura para as últimas questões filosóficas, ou seja, uma ruptura ou “desmecanização" do tempo cotidiano. É nesse potencial "desmecanizador”, desconstrutivo, que pode haver uma força diacrônica do cômico, do satírico, do carnavalesco: uma força da atitude irresponsável como o não sério que aponta para uma responsabilidade do acontecimento.

Uma das principais coisas que Woland faz é restaurar fantasticamente o manuscrito de um romance dentro do romance - do romance do personagem Mestre que dá título à obra de Bulgákov - na realidade soviética, o qual havia sido destruído por conta da proibição de sua publicação pelo aparato burocrático-administrativo stalinista. Ao ditatorialmente repor na realidade soviética o discurso de um outro, acaba por "desmecanizar" e evidenciar as relações do discurso com verdade e poder até mesmo para além da própria realidade soviética.

Desse modo, se entendemos que a prosa de Bulgákov, em especial em $O$ Mestre $e$ Margarida, de algum modo esteja intimamente ligada à sátira menipeia, como desde o início pareceu ser o caso, poderemos a partir de agora entrever o fundo complexo histórico, cultural e filosófico em que o romance se movimenta. Ao procurar ser o satírico de seu tempo, parodiando o realismo socialista, o fáustico, Gógol, entre tantas outras coisas, podemos observar como Bulgákov acaba atuando também para além da superfície de seu tempo. A seguir, procuramos dar alguma forma lógico-discursiva a essa ideia a partir de uma consideração mais detida sobre o potencial filosófico do satírico no romance de Bulgákov, procurando entender como isso ocorre no problema específico da ligação entre os assim chamados "dois mundos" de O Mestre e Margarida.

$* *$

Invocando uma assim chamada "competição hermenêutica" entre estudiosos do mundo inteiro para compreender o romance $O$ Mestre e Margarida a partir dos mais variados instrumentos 
críticos, bem como recusando uma "leitura "ingênua" do romance, Vittorio Strada sugere em seu curto texto "O Mestre e Margarida", no livro A cultura do romance, que

A melhor maneira de entrar no mundo mágico de $O$ Mestre e Margarida, em vez de repetir a relação das "fontes" compiladas pelas leituras intertextuais ou de aumentar o labirinto de significados ocultos rastreados pelas leituras interpretativas será, então, colocar uma pergunta falsamente "simples", mas adequada à falsa "simplicidade" do texto, pergunta esta que um famoso "formalista" russo, Boris Eichenbaum, tinha se colocado sobre a obra de um autor predileto de Bulgákov, a saber, sobre $O$ capote, de Gógol. Podemos nos perguntar: "como é feito O Mestre e Margarida?". (STRADA, 2009, p. 1008).

Se podemos entender esta passagem como uma reivindicação por uma leitura do romance que cria seus problemas a partir do próprio romance, a pergunta com a qual ela se encerra dá o tom de como dar prosseguimento à análise: ela se desdobra na questão de como se dá a união dos dois romances - o romance escrito no interior de $O$ Mestre e Margarida e a história da sua recuperação - que, segundo o crítico italiano, coabitam na obra de Bulgákov: “O Mestre e Margarida é uma união de dois romances, um 'romance no romance', mecanismo não inédito (ao lado do 'teatro no teatro'), mas aqui substancialmente renovado" (STRADA, 2009, p. 1008). Parece que uma tal leitura do romance, uma que está interessada em destrinchar e pôr à luz os seus mecanismos de organização literária, tem de ter como função explicar como se dá a relação entre esses dois universos.

Também podemos ver Weir indo ao encontro dessa posição, ao defender que o problema dos sistemas literários em $O$ Mestre e Margarida tem sua razão de ser por promover um entrelaçamento autorreflexivo da tradição literária entre os séculos XIX e XX, e os séculos XX e XXI e que o decisivo reside ainda em descrever como ocorre esse entrelaçamento:

It is easy to accept the assertion that The Master and Margarita uses modernist literary devices (especially in the Moscow story) to play out traditional novelistic concerns (especially in the Pilate story). Even though the novel often playfully dramatizes its fictiveness, it inevitably circles back to themes of good and evil, love and infidelity, and artistic freedom, all of which were well tested by the romantic and realist novels of the previous century. What may be less obvious, and therefore less easily accepted, is that Bulgakov designs the novel to be a self-reflexive transmitter of literary tradition; a mediator between nineteenth- and twentieth-century literature from one perspective and between pre- and post-Soviet literature from another. To patch the rended fabric of history and literary tradition - this is one of the reasons why the novel fits together the way it does. What significantly remains is to describe how it fits together the way it does. ${ }^{49}$ (WEIR, 2002, p. 25).

49 "É fácil aceitar a afirmação de que $O$ Mestre e Margarida usa de dispositivos literários modernistas (especialmente na estória em Moscou) para exaurir preocupações do romance tradicional (especialmente na estória 
Mas, para Strada, esses dois romances se desdobram na verdade em três, já que, para o autor, o romance dentro do romance, sendo "a reescrita de um outro livro, que ele [o Mestre, seu pretenso autor] considera não corresponder à realidade dos fatos nele narrados, é a reescrita de um livro sagrado: o Evangelho" (STRADA, 2009, p. 1009). O romance dentro do romance conteria um outro texto narrativo como referência, como se houvesse "uma terceira caixinha chinesa ou uma terceira boneca russa" (STRADA, 2009, p. 1009). Ora, mas será que é assim mesmo?

Essa pergunta surge pois, ao analisar acima algumas situações dialogais da narrativa da ressurreição do romance perdido, pudemos perceber a sua semelhança com algumas estruturas do romance realista socialista, pelo que sugerimos que ela é uma paródia deste tipo de romance. Se estivermos corretos em nossa sugestão, deveremos então nos perguntar se $O$ Mestre $e$ Margarida tem apenas três narrativas envolvidas na sua concepção, ou se são quatro (essa quarta não como um romance realista socialista específico, mas como a estrutura geral do gênero). Se forem quatro, nada impede que sejam ainda mais. Sendo mais, a relação entre esses dois romances que se desdobra na relação com mais romances depende de se determinar com quantos mais romances ou textos (e quais) essa relação se dá. Por exemplo, no próprio romance do Mestre podemos encontrar indícios de que na sua concepção está diretamente envolvida a versão nietzschiana do Evangelho, exposta no seu $O$ Anticristo (1888). Quanto a isso, seria preciso perguntar ainda por que Strada faz referência apenas ao Evangelho como um texto exterior ao romance (e, portanto, exterior à imanência restrita do texto) e por que, fazendo referência a este, não faz aos outros.

Mas mesmo que pudéssemos determinar quantos textos narrativos estão contidos dentro do texto narrativo (quantas bonecas russas dentro da boneca russa) unicamente a partir da leitura crítica de $O$ Mestre e Margarida, podemos nos perguntar até que ponto a questão pela relação entre esses romances encerra o problema mais profundo do modo como o romance foi feito, ou, pelo menos, da relação entre as duas narrativas que textualmente habitam o romance. Mas, para Strada, é importante que sejam não dois romances, mas três. A linha do argumento é a seguinte:

de Pilatos). Mesmo que o romance muitas vezes dramatize sua ficcionalidade de modo jocoso, ele acaba inevitavelmente voltando a temas como bem e mal, amor e infidelidade, e liberdade artística, todos os quais foram bem examinados pelos romances românticos e realistas do século anterior. $\mathrm{O}$ que é menos óbvio, e consequentemente não tão facilmente aceito, é que Bulgákov projeta o romance para ser um transmissor autorreflexivo da tradição literária; um mediador entre a literatura dos séculos 19 e 20 a partir de uma perspectiva, e, de outra, entre a pré- e a pós-soviética. Remendar o tecido rasgado da história e da tradição literária - esta é uma razão porque o romance está montado do modo como está. O que permanece decisivo é descrever como é o modo que ele está montado." (Tradução nossa). 
Strada subordina a sátira bulgakoviana ao estudo da "situação paradoxal" do primeiro capítulo do romance. Ocorre que tal estudo depende de compreender o "duplo enigma" da epígrafe do romance, que, por sua vez, pode explicar, para o crítico, a "relação entre Woland e Hanozri" (STRADA, 2009, p. 1010). E aí ele dá o pulo do gato: esta é "a questão metafísica" que é o fundo da questão pelos "mecanismos de ligação entre os três diferentes sistemas narrativos" (meu grifo):

O ser misterioso que chega à terra, a Moscou, em pleno regime comunista, para punir os perseguidores do Mestre e proteger a ele e ao manuscrito, o ser que, além de desempenhar essa função, pode avaliar a obra do Mestre e comprovar a verdade do texto, pois foi testemunha dos eventos narrados, este ser é o Demônio, com o nome de Woland no romance. Não se trata, portanto, apenas de mecanismos de ligação entre os três diferentes sistemas narrativos (o do presente, o do passado e o do eterno, além do metassistema que permeia o conjunto: o do amor, nas duas hipostasias, a do amor terreno e do amor celeste): trata-se da relação entre Woland e Hanozri, isto é, de uma questão metafísica, como já sugere a epígrafe do romance, extraída do Fausto, de Goethe, onde a pergunta "quem é você" é respondida enigmaticamente "uma parte daquela força que quer constantemente o Mal e pratica constantemente o Bem". Duplo enigma [...]. (STRADA, 2009, p. 1010).

Desse modo, se podemos intuir, a partir da relação com o Fausto de Goethe aludida pelo crítico, ser este drama ou ao menos a tradição fáustica (como no caso do realismo socialista) outro texto constituinte da elaboração do romance de Bulgákov - o que Strada não faz -, a relação entre Woland e Hanozri - entre as personificações de bem e mal - é o que determina para Strada em última instância a questão da relação entre o romance e o romance dentro do romance. É difícil de entender o estatuto do terceiro romance - o Evangelho que, no entanto, não aparece nenhuma vez no romance - em sua interpretação, mas de algum modo ele leva à ideia de que haveria três sistemas narrativos em $O$ Mestre e Margarida. Mas não há três romances nem três sistemas narrativos: ou só há dois ou inúmeros - ele mesmo afirma haver ao menos outro "metassistema", o do amor. Fica, aliás, obscuro se os sistemas respondem a um critério de temporalidade, de conteúdo continente (bonecas russas), ou se a algum outro critério. Além disso, não encontramos aí nenhuma referência a um procedimento satírico próprio de Bulgákov, nem à possibilidade de esse procedimento determinar previamente a relação Woland-Hanozri - e todos os outros sistemas e metassistemas que por ventura encontrarmos no romance -, que só ocorre "presencialmente" uma única vez no texto, ao contrário das muitas situações dialogais do romance que quase não são mencionadas por Strada e que igualmente têm extrema relevância. Strada parece cair no mesmo problema que aponta nos outros 
estudiosos do romance: coloca a questão "metafísica" (que seria antes teológica ${ }^{50}$ ) acima da questão do modo como o romance foi feito - daí a necessidade dos três sistemas narrativos, e também a dificuldade de entender o estatuto do Evangelho como sendo para ele o romance dentro do romance dentro do romance.

Ademais, esses três "diferentes sistemas narrativos" estão baseados em um estudo das temporalidades: se a história de Jesus se passa no passado, a de Moscou no presente, a terceira não ocorre no futuro, mas no "supratemporal" - o eterno, que é o da "salvação" do Mestre e da Margarida. Ora, mas não é bem assim. Há um futuro na obra, ao menos em três momentos: (a) Woland discute com Berlioz a questão do governo dos homens: o futuro se abre ao acaso, e o mero planejamento de algo não implica que esse algo irá acontecer; (b) pouco antes de morrer, o Mestre diz para Ivan que este irá escrever a continuação da história; (c) o "Epílogo". Nele, Ivan, já professor de história, se lembra de certos acontecimentos uma vez por ano durante o solstício de verão ${ }^{51}$. Ora, se não são três as temporalidades do romance, não são três bonecas russas (romances dentro do romance) e não são três sistemas narrativos, pelo que os mecanismos que explicam a relação entre as duas narrativas do romance não são revelados na interpretação de Strada, e a questão pelo modo como o romance foi feito, por sua vez, fica sem resposta.

O problema residiria, assim, no elo entre as duas narrativas, o que leva à pergunta por quem é autor da segunda narrativa: alguns respondem Woland, outros Biezdomni. Não se discute se é possível que o romance dentro do romance tenha múltiplos autores, ou que a relação entre esses romances possa ser de outra espécie. Também podemos perceber que, embora se faça uso da leitura de versões anteriores dos manuscritos de O Mestre e Margarida para fundamentar os argumentos de que é Biezdomni ou Woland o autor, não há nenhuma referência a uma análise conjunta da prosa de Bulgákov, com o que poderiam perceber que problemas

\footnotetext{
${ }^{50}$ Strada fala em "metafísica" e "filosofia" com pouca acuidade terminológica: chamaremos, a seguir, o problema entre "bem" e "mal", entre Woland e Haznori de problema teológico ou de teologia - a não ser, é claro, quando fazemos citação direta de Strada -, pois esse problema, uma questão moral, foi tratado por Strada desde um ponto de vista religioso ao identificá-los justamente com as personagens Woland e Haznori. Essa confusão pode ter ocorrido, entre outros motivos, por ele ter interpretado de modo direto os arquétipos fáusticos como arquétipos cristãos, que de fato, em alguma medida, o são. Mas a relação não é tão simples e tão direta quanto o autor faz parecer.

51 O "Epílogo" foi a última parte escrita por Bulgákov, já próximo do fím de sua vida. A favor de Strada, poderíamos pensar que ele é uma espécie de adendo ou anexo, exterior ao romance propriamente dito. Em contrapartida, uma vez estar ele escrito e publicado junto do romance, faz parte deste e, com isso, pode estar querendo resolver justamente a falta de uma dimensão de futuro do romance, a fim de evitar algumas interpretações. Se o "Epílogo" foi escrito como uma tentativa de consertar e explicitar algumas questões antes não explícitas (o que é apenas uma hipótese), aí é que ele tem ainda mais significado e não deveria, de modo algum, ser descartado em uma análise.
} 
semelhantes já estão presentes - como o de determinar o estatuto do narrador-autor no texto "As aventuras de Tchítchikov".

Houvesse sido feito isso, tanto Strada quanto os críticos que Weeks estuda teriam considerado com mais acuidade o procedimento satírico que não deixa de operar em nenhum momento do romance. Sem a observação desse procedimento, qualquer tentativa de análise dos mecanismos de sua composição não tem como obter êxito. Levar a sátira em consideração evitaria pensar, por exemplo, que o Evangelho seria o único romance dentro do romance dentro do romance, pois, em geral, a prosa de Bulgákov não parodia uma única obra, como temos afirmado.

Consequentemente, o erro talvez seja pensar no modelo das bonecas russas quanto às narrativas exteriores ao romance: o Evangelho não está dentro do romance do Mestre, ele está parodiado ali, bem como outros textos, como $O$ Anticristo de Nietzsche, ou, no caso da narrativa soviética, certos elementos fáusticos e certa estrutura do realismo socialista, entre outros (quem sabe?). Mas, se o Evangelho e esses outros textos não são outras bonecas russas, ainda nos ronda o problema da relação entre as duas narrativas que parece ainda se encaixar nesse modelo: está o romance do mestre dentro da narrativa soviética? Se sim, como?

1. Uma possibilidade de entender a estrutura em forma de boneca russa (romance dentro do romance) a partir da sátira pode ser a de ver essa estrutura como uma atualização do gênero satírico no contexto do romance moderno (como vimos, Strada afirma que esse procedimento não é novo). Ao mesmo tempo, pode ser paradoxalmente uma paródia da sua estrutura, ao corroer os mecanismos com que essas duas instâncias se ligam: não é uma mera adaptação aos novos romances europeus, mas uma adaptação que já traz a corrosão dessa estrutura. Se for assim, a pergunta deve ficar em aberto, e é na indeterminação de sua resposta que a interpretação da relação entre as duas narrativas deve se erguer. Algo parecido com o caso da dúvida sobre a traição de Capitu. Os argumentos dessa hipótese se pareceriam também com a ideia de que a literatura periférica está ao mesmo tempo mais atrasada e mais avançada do que a do centro, o que poderia nos levar a pensar se não estaríamos enquadrando exageradamente O Mestre e Margarida em padrões de análises prévios, deixando de perceber as especificidades do romance de Bulgákov.

2. Outra hipótese para entender como ocorre a paródia na relação entre as duas narrativas (que não exclui a primeira e pode, inclusive, complementá-la) seria observar essa relação do ponto de vista da linguagem, o que não aparece nem em Weeks nem em Strada. Como vimos, o gênero da menipeia "[combina] a ousadia da invenção e do fantástico [...] com um excepcional 
universalismo filosófico e uma extrema capacidade de ver o mundo" (BAKHTIN, 2013, p. 131) a fim de experimentar as últimas posições filosóficas. Talvez o problema filosófico para o qual o fantástico abre o romance seja outro do que o de conteúdo-continente, ou seja, o de se perguntar o que está contido em quê. Tal como a questão de Woland por quem governa os homens se Deus não existe não vai parar em existencialismo, mas coloca mais precisamente o problema dos critérios de verdade do discurso, o problema da relação entre esses dois romances não vai parar em um problema de teoria dos conjuntos, mas põe, na verdade, o problema da autoria do discurso. Isso é posto tanto em relação com a questão sobre de onde fala aquele que fala - quem é e de onde fala o autor desse romance dentro do romance, desse romance que é parodia de um assim chamado texto sagrado, o Evangelho? -, como também com a pergunta sobre se o discurso tem um único autor que o organiza - o autor desse romance dentro do romance é um só? A questão teológica entra de soslaio aqui de uma outra maneira, satirizada: o religioso que não faz a pergunta pela procedência do texto sagrado não é livre nem responsável na medida em que não pratica uma relação autêntica entre verdade e poder, entre o que diz (ou repete) e o que faz. Mas de modo algum a pergunta orienta categoricamente como o romance foi feito, e muito menos dá conta de explicar a relação entre os seus níveis narrativos. A teologia é apenas um caso particular do que está sendo testado aqui: a relação entre discurso e prática do autor do discurso.

Avançando nesta hipótese, aqueles que têm afinados no mesmo diapasão seus atos e suas falas são capazes de distinguir claramente as duas narrativas, as duas realidades; já quando o romance no romance entra na narrativa soviética entre aqueles que não têm fala e atos concordados, o que o leitor experiencia é uma difusão entre as duas narrativas, entre as duas realidades. Compilamos aqui as passagens que procuram conectar as duas narrativas para que possamos analisar até onde é possível avançar com essa hipótese:

1. - Não é preciso nenhuma prova - respondeu o professor, e pôs-se a falar baixinho; o seu sotaque tinha desaparecido, não se sabe como. - Tudo é muito simples: no décimo quarto dia do mês primaveril de Nisã, numa manhã, bem cedo, usando um manto branco com forro cor de sangue e tendo o andar arrastado como o de um cavaleiro... (BULGÁKOV, 1992, p. 24)

Na primeira vez em que o romance dentro do romance surge em $O$ Mestre e Margarida, ele sai fantasticamente da boca de Woland, como uma prova de que Jesus existiu - uma prova, aliás, um tanto quanto fantástica e que de prova não tem nada. As últimas palavras do capítulo anterior repetem as primeiras do capítulo seguinte, que é o do romance que se passa em Jerusalém. 
Embora o leitor perceba bem definida a mudança de realidades com as mudanças de capítulos, o estatuto de realidade desse romance dentro do romance é bastante dúbio no momento em que a narrativa no Oriente Médio acaba e, já no terceiro capítulo, volta-se à narrativa soviética:

- Sim, eram cerca de dez horas da manhã, estimado Ivan Nicolaievitch - disse o professor.

O poeta passou a mão pelo rosto como uma pessoa que acaba de voltar a si, e viu que no lago do Patriarca já era noite. [...] "Como é que não percebi que ele tinha forjado toda uma história?..." pensou Biezdomni, pasmado. "Vejam só, já chegou a noite! Ou talvez não tenha sido ele quem contou, e eu apenas adormeci e vi tudo isso num sonho?"

Mas era preciso supor que o narrador de tal história fora o professor. Caso contrário, seria preciso admitir que Berlioz tivera o mesmo sonho, pois ele disse escrutando com o olhar, o rosto do estrangeiro. (BULGÁKOV, 1992, p. 49).

Não é sonho, como no caso de "As aventuras de Tchítchikov", mas também não é propriamente um romance: é uma outra realidade que se impõe sobre a realidade da primeira narrativa, talvez como uma paródia do cinema (parente da lanterna mágica que tanto entusiasmou Goethe), mas muito mais poderosa: uma verdadeira realidade virtual que se efetiva na realidade propriamente dita. Isso ao menos do ponto de vista de Ivan e de um narrador em terceira pessoa que parece estar tentando pensar como Ivan - quanto a Berlioz, não sabemos exatamente como foi que ele percebeu a narrativa que saiu da boca de Woland. De qualquer modo, nesse momento, essa efetivação de uma realidade virtual parece ser o poder do demônio.

Já na segunda vez em que a narrativa na Moscou soviética é interrompida para a entrada do romance dentro do romance, ela surge como um sonho de Ivan já no sanatório, repetindo o mesmo procedimento anterior - as primeiras frases do capítulo seguinte adentram o capítulo anterior, que termina em reticências, talvez com a intenção de diminuir a experiência do leitor de interrupção da narrativa, ao quebrar a página e se iniciar um novo capítulo:

2. O último a dormir foi Ivan, quando o ar sobre o rio já clareava. Depois do remédio que impregnou todo o seu corpo, a tranquilidade veio como uma onda que o cobriu. O seu corpo tornou-se mais leve e a sonolência arejava a sua cabeça com um sopro agradável. Ele adormeceu, e a última coisa que ouviu na realidade foi o gorjear dos pássaros na floresta, mergulhada ainda na aurora matutina. Mas logo os passarinhos também se acalmaram, e ele sonhou que o sol já se punha sobre o Monte Calvo, e que em torno do monte havia dois cordões de isolamento... (BULGÁKOV, 1992, p. 187). 
Seria esse sonho "encucado" em Ivan pelo Satanás ou pela injeção que a enfermeira Prascovia Fiodorovna lhe receitou para acalmá-lo? Não é explicação alguma pensar que o sonho fora causado por sua perturbação psicológica. Aqui, a questão não se resolve: como é que Ivan sonhou exatamente as mesmas palavras e frases do romance pretensamente escrito pelo Mestre - ou ele sonhou em imagem o que teria sido escrito pelo Mestre? Pouco antes, a conversa que tem com o Mestre termina com Ivan pedindo: “-Diga-me, o que aconteceu a seguir a Jeshua e Pilatos? - pediu Ivan. - Eu lhe imploro, quero saber" (BULGÁKOV, 1992, p. 165). E o Mestre responde: “- Ah, não, não - respondeu o visitante, contorcendo-se dolorosamente - não posso recordar o meu romance sem tremer. Seu conhecido lá do lago do Patriarca faria isso melhor do que eu. Obrigado pela palestra. Até logo" (BULGÁKOV, 1992, p. 165). Poderia isso indicar que o sonho é obra de Woland, ao menos enquanto detentor de poderes de deus ex machina, ou seja, de algo que explica o que não tem explicação, com o que a própria explicação deixa de ser uma necessidade?

Talvez possa nos dar alguma direção a passagem a seguir, em que os manuscritos desse romance dentro do romance aparecem escatologicamente embaixo do gato fantástico Bieguemot. A cena, aliás, vale a pena ser reproduzida, pois talvez seja a maior evidência do caráter satírico da relação entre as duas narrativas:

- Deixe-me ver [o manuscrito] - Woland estendeu a mão com a palma para cima.

- Infelizmente não posso fazê-lo - disse o Mestre - pois queimei o manuscrito no fogão.

- Desculpe-me, não acredito - respondeu Woland - isto é impossível. Os manuscritos não se queimam. - Ele se virou a Bieguemot e disse: - Bieguemot, dê-me o romance.

$\mathrm{O}$ gato saltou imediatamente da cadeira e todos viram que ele estava sentado sobre um maço volumoso de manuscritos. Ele pegou o exemplar que estava em cima e entregou-o, com uma reverência, a Woland. Margarida tremeu e gritou, novamente emocionada a ponto de chorar:

- Ei-lo, o manuscrito! Ei-lo!

Ela se lançou a Woland e acrescentou com um ar de admiração:

- É todo-poderoso! Todo-poderoso! (BULGÁKOV, 1992, p. 314-5).

Como entender este "Todo-poderoso"? Se achamos que o romance está alicerçado na relação entre o bem e o mal, entre Woland e Hanozri, vamos interpretar essa exclamação de Margarida como uma afiliação ao demônio elevado à onipotência, mas que ainda é apenas parte constitutiva das forças do bem, o que não condenaria Margarida. No entanto, podemos entender essa onipotência de outro modo: o que Woland faz é restaurar magicamente o manuscrito do romance dentro do romance - do romance do Mestre -, recolocando na realidade da narrativa 
moscovita um texto parresiástico que foi excluído de realidade. O que ele faz aqui é paradoxalmente restaurar, com sua "onipotência" mágica - e, portanto, com sua vontade de potência extraordinária - as relações do discurso com verdade e poder: Woland repõe paradoxalmente na realidade soviética o discurso de um outro. Desse modo, mais do que se perguntar qual a relação entre a narrativa e a narrativa dentro da narrativa, talvez a questão aqui deveria ser a de o que é um livro e quais são as suas determinações materiais? Esse episódio nos faz perguntar sobre o que não costumamos nos perguntar quando, por exemplo, lemos um livro. Um livro é um meio, uma mídia - o truísmo que esconde o verdadeiro problema dessa passagem - que foi escrito e produzido por alguém, com alguma intenção. O fiofó do gatodemônio como imprensa problematiza esse truísmo ao satirizar a relação entre o material (manuscrito, livro) e o aparato que o produz, desmecanizando a leitura.

Nesse sentido, a sátira põe em jogo o problema ético da relação entre discurso e poder do ponto de vista mais cru e material: as condições de possibilidade de organização e estruturação do aparato de inscrição para a publicação e circulação de um texto. A colocação desse problema de modo algum dá prazer ao governante - como pensa Safatle -, mas sim o põe a nu. Ao mesmo tempo, contudo, por conta das duas noções de paródia operando no romance, esse ato de pôr o tirano a nu também é tirânico em $O$ Mestre e Margarida.

Com isso, ele coloca um problema não moral - e, portanto, religioso -, mas ético: não é o interior dos indivíduos que está em jogo, ou até é, mas apenas na medida em que as suas relações como um todo são efetivadas na realidade por meio de suas práticas discursivas que, quando escritas, estão registradas em um aparato material. Bem e mal têm como critério o estabelecimento dessas práticas: Woland faz o bem ao reestabelecê-las, mas o faz de modo mal, ao fazê-lo por meio de seu poder extraordinário. Hanozri institui por sua vez também essa prática em que a fala e o ato se "con-dizem”, mas não usa nenhum poder extraordinário para forçar o estabelecimento geral dessa prática: fica a critério dos que estão à sua volta o fazerem ou não. Pilatos detinha um poder, mas não o usa para estabelecer uma relação dialógica franca, e acaba se arrependendo eternamente - ao menos eternamente ("doze mil luas") até Margarida pedir que ele fosse liberado. Seu maior desejo? Dialogar socrática (Bakhtin) ou parresiasticamente (Foucault) com Hanozri.

Assim, ao interpretar "bem" e "mal" como critérios das relações dialogais e de poder que se estabelecem no romance, podemos, portanto, classificar todos os personagens e situações de $O$ Mestre e Margarida a partir deles. Se isso for verdade, então são eles que organizam e estruturam o romance, e a questão religiosa ou moral pode tanto ser lembrança de certo caráter 
irredutível da subjetividade e da personalidade, como estar ao mesmo tempo parodiada, de modo a abrir-se ao ético. Podemos ver se esses critérios são aplicáveis, por exemplo, na última vez que ocorre uma mudança de narrativas no romance:

3. Depois de chorar à vontade, Margarida tomou um dos cadernos e encontrou o lugar que tinha relido antes do encontro com Azazello junto da muralha do Kremlim. Não queria dormir. Ela acariciava o manuscrito como se este fosse um animal de estimação; virava-o e examinava todos os seus lados, ora se detendo no título, ora abrindolhe o fim. De repente ocorreu-lhe a ideia terrível de que tudo não passara de feitiçaria, que dentro de um instante os cadernos desapareceriam e ela estaria novamente no seu dormitório, na mansão, e que depois de acordar ela teria que se afogar. Mas esta foi a sua última ideia terrível - uma repercussão dos seus longos sofrimentos. Nada desaparecia; Woland todo-poderoso era realmente todo-poderoso, e Margarida podia folhear os cadernos que faziam um frufru suave, o quanto quisesse, mesmo até a madrugada; podia examiná-los, beijar e reler as palavras:

"As trevas vindas do Mediterrâneo cobriram a cidade que o procurador tanto odiava"... Sim, as trevas... (BULGÁKOV, 1992, p. 326).

Margarida é a única que lê o romance que voltou extraordinariamente à existência após a intervenção escatológica da trupe fantástica. Este também é o único momento em que é com a fala do narrador em terceira pessoa (ou a fala de Margarida?) que se encerra (com duplas reticências) o capítulo anterior à narrativa em Jerusalém. Talvez por isso, quando do retorno à narrativa soviética no próximo capítulo, não encontremos nenhuma dúvida quanto ao status de realidade de uma narrativa e de outra: "Quando Margarida chegou às últimas palavras do capítulo '...Foi assim que o quinto procurador da Judéia, Pôncio Pilatos, recebeu o amanhecer do décimo quinto dia do mês de Nisã', o dia raiou" (BULGÁKOV, 1992, p. 359). Margarida está junto com o Mestre no polo daqueles que têm um discurso compatível com seus atos: ela pactua com as forças do mal por seu amor, passando por uma série de sacrifícios que atestam a veracidade de seu discurso, por isso ela entende os limites entre as realidades. Agora já não é mais preciso ter uma (oni)potência para reestabelecer a ordem.

Já quanto à temporalidade - que para Strada tem uma relação com a estrutura de boneca russa do romance -, também é possível explorá-la a partir da questão da linguagem, e em dois aspectos: (a) Diferentemente do aventado por Strada de que ela comporia três sistemas narrativos, podemos ver sua relevância na relação entre autoria e texto quando este se passa e trata do presente, e quando este se passa e trata do passado. Em ambos os casos, a fronteira entre ficção e realidade é tênue, mas no segundo ela pode ser expressa na ambiguidade entre história e estória, entre historiador e estoriador (ou poeta?) que Bulgákov explora - Woland diz 
ser professor de história; Ivan é poeta e depois se torna professor de história; o Mestre é historiador mas escreveu um romance etc.; (b) Já quanto à temporalidade que Strada chama de eterno - o momento da "salvação" do Mestre e da Margarida - não encontramos diretamente um problema da linguagem, como no caso anterior. Ela precisa ser interpretada ao lado de vários outros momentos em que tempo e espaço são modificados no interior do romance. Geralmente essa modificação é a da dilatação, podendo dar, no caso do tempo, uma sensação de que ele não está passando. Alguns exemplos dessas situações:

(i) A aparição de "um homem transparente, de aspecto muito esquisito" para Berlioz:

Então o ar abrasador condensou-se diante dele, e desse ar teceu-se um homem transparente, de aspecto muito esquisito. Vestia um curto paletozinho xadrez, também feito de ar, e um boné de jóquei cobria a sua pequena cabeça... o homem tinha mais de dois metros de altura, mas era excepcionalmente magro e de ombros estreitos; em sua fisionomia - peço que observem isso desenhava-se o escárnio.

A vida de Berlioz transcorrera de tal maneira que ele não estava habituado a fenômenos extraordinários. Empalideceu ainda mais, arregalou os olhos e pensou, peturbado: "isto não pode ser"...

Mas aquilo, infelizmente existia; o homem alto, através do qual se via tudo, balançava-se diante dele para a esquerda e para a direita, sem tocar a terra com os pés. (BULGÁKOV, 1992, p. 13-4).

(ii) A despeito do fato extraordinário de um gato andar em duas patas e pagar o bonde, aqui queremos destacar o que o narrador, seguindo próximo à subjetividade de Ivan, chama de

[...] velocidade sobrenatural com que se realizava a perseguição. Há apenas vinte segundos ele estava junto do portão Nikitski e agora já o deslumbravam as luzes da Praça Arbat. Mais alguns segundos e eis uma ruela escura com calçadas tortuosas, onde Ivan Nicolaievitch caiu e machucou o joelho. Novamente uma via bem iluminada, a Rua Kropotkine, mais uma ruela, depois a Rua Ostojenka e mais uma travessa triste, nojenta e mal iluminada. (BULGÁKOV, 1992, p. 58).

Talvez o mais importante nesta passagem seja que por mais que "o poeta acelerava o passo e chegou mesmo a correr, empurrando os transeuntes, não se aproximou nem um centímetro do professor" (BULGÁKOV, 1992, p. 58).

(iii) Todo o episódio com o diretor do Teatro de Variedades de Moscou, que foi parar em Ialta de modo inexplicável com as leis da física. Nesse episódio, a potência (Macht) da técnica moderna não é páreo para a onipotência (Allmacht) fantástica: 
Varenukha parou de correr e berrou:

- Pensei! Já pensei nisso! Até Sebastopol pela estrada de ferro são cerca de mil e quinhentos quilômetros. E dali até Ialta mais oitenta. Mas por via aérea certamente dá menos... um caça? Mas quem deixaria Stiopa entrar descalço num avião militar? Para quê? Talvez ele tenha tirado os sapatos depois de chegar a Ialta? Permanece a questão: para quê? Mas mesmo calçado ninguém o deixaria entrar num caça! Aliás, o caça não tem nada que ver com o caso. Ora, mas está escrito que ele apareceu na polícia às onze e trinta e a conversa telefônica em Moscou foi... mas quando mesmo... - aí diante dos olhos de Rimski surgiu o mostrador do seu relógio... Ele recordou a posição dos ponteiros. Que horror! Eram onze e vinte. Mas o que é isso! Supondo-se que logo depois da conversa telefônica Stiopa tivesse corrido para o aeroporto e chegado lá em cinco minutos, o que, a propósito, é impossível, o avião, decolando imediatamente, percorreu em cinco minutos mais de mil quilômetros? Portanto, a sua velocidade superou doze mil quilômetros por hora!!! Mas isto é impossível, logo, ele não pode estar em Ialta. (BULGÁKOV, 1992, p. 119).

(iv) Mas ele estava em Ialta, assim como o apartamento de $\mathrm{n}^{\circ} 50 \mathrm{em}$ um grande edifício de seis andares na Rua Sadovaia havia se dilatado espacialmente com a entrada dos novos inquilinos sinistros e fantásticos, de tal modo que chega a surpreender Margarida: “'- Não - respondeu Margarida - o que me surpreende acima de tudo é a quantidade de coisas que cabe aqui. - Ela fez um gesto com a mão, ressaltando desta maneira a imensidão da sala” (BULGÁKOV, 1992, p. 274).

A resposta de Koroviev nos dá uma pista para entender esse fenômeno da dilatação de tempo e espaço:

- Isso é o mais simples de tudo! - respondeu ele. - Os que conhecem bem a quinta dimensão podem expandir sem nenhuma dificuldade o recinto até os limites desejados. Posso dizer-lhe mais, estimada senhora, até os limites que só o diabo conhece! [...]. (BULGÁKOV, 1992, p. 274).

(v) A "quinta dimensão" tem alguma coisa que ver com essa dilatação espacial, mas também com a temporal, como a temporal que ocorre no baile do Satanás, que se passa todo sem que o relógio avance além da meia-noite e que é o ápice dessa dilatação. Após tomar o sangue vertido na taça-cabeça-de-Berlioz, Margarida

teve a impressão de que galos ensurdecedores cantavam ao lado; em algum lugar tocavam uma marcha. A multidão de convidados começou a perder o seu aspecto. Os homens de fraques e as mulheres reduziram-se a pó. Aos olhos de Margarida a podridão abrangeu toda a sala; acima dela fluiu o cheiro de cripta. As colunas dissiparam-se, as luzes apagaram-se, tudo se encolheu e não havia mais fontes, nem tulipas ou camélias. E tudo voltou simplesmente a ser o que era: a modesta sala de visitas da mulher do joalheiro onde uma porta entreaberta deixava passar uma faixa de luz. E Margarida entrou por essa porta semiaberta. (BULGÁKOV, 1992, p. 302). 
Ao fazer isso, Margarida entra no dormitório de Woland, onde "tudo estava como antes do baile” (BULGÁKOV, 1992, p. 303), e um pouco mais para frente, o Mestre surge no quarto depois que "a cortina pesada afastou-se, a janela escancarou-se e na longínqua altitude revelouse a lua cheia; não a lua da madrugada mas a da meia-noite” (BULGÁKOV, 1992, p. 312). Ainda mais para frente, a meia-noite continua:

- Não compreendo uma coisa... A meia-noite está durando nem sei quanto tempo, embora a manhã já devesse ter raiado há muito!

- É gostoso prolongar um pouco a meia-noite festiva - respondeu Woland. Bem, desejo-lhes boa sorte! (BULGÁKOV, 1992, p. 321).

Se podemos ver nessa dilatação do tempo e do espaço um procedimento satírico correlato à hiperbolização, também é preciso levar em consideração a ideia da "quinta dimensão" presente na fala de Koroviev. Essa talvez seja uma referência à teoria de P. Florenski, um matemático muito ligado à religião ortodoxa cujas palestras Bulgákov teria frequentado. Aliás, quando perguntado sobre as dificuldades interpretativas de $O$ Mestre $e$ Margarida em alguma de suas leituras para um círculo de amigos, aludia sempre a essa questão. A "quinta dimensão" parece ser um artifício narrativo para tornar ambíguos os truques que modificam a experiência de espaço e de tempo e, consequentemente, também as relações entre as duas narrativas, na medida em que pode satiricamente sugerir a possibilidade de inviabilizar o juízo decisivo do leitor sobre esses fenômenos serem "reais" - meros truques de magias - ou fantásticos. Em outras palavras, trata-se de um dispositivo de verossimilhança da narrativa que contribui para e acentua seu caráter ambíguo e autorreflexivo.

Como vimos, em $O$ Mestre e Margarida as soluções tradicionais para tornar verossímeis os acontecimentos fantásticos são satirizadas, ao mesmo tempo em que o narrador deixa de assumir a função de deus ex machina como em "As aventuras de Tchítchikov" e de certa maneira nas Almas mortas de Gógol, doando tal função a Woland (ver capítulo anterior). Se anteriormente nos detivemos em algumas consequências disso para o narrador, agora queremos pensar seu significado para a figura de Woland. Já aqui podemos ver a reivindicação do poder de deus ex machina por parte de Woland, o que, aliás, condiz com suas características mefistofélicas:

- Eu sou historiador - confirmou o estudioso, e acrescentou, fora de propósito: - Hoje, à noitinha, no lago do Patriarca, terá lugar uma história interessante! 
E mais uma vez, o redator e o poeta ficaram pasmados ao máximo. O professor fez-lhes sinal para que se aproximassem e, quando eles se inclinaram em sua direção, murmurou:

- Tenham em conta que Jesus existiu.

- Bem, professor - respondeu, Berlioz, sorrindo a contragosto - respeitamos os seus vastos conhecimentos, mas o nosso ponto de vista a este respeito é diferente.

- Não é preciso nenhum ponto de vista! - respondeu o estranho professor simplesmente ele existiu, e nada mais.

- Mas é preciso alguma prova... - ensaiou Berlioz.

- Não é preciso nenhuma prova - respondeu o professor [...]. (BULGÁKOV, 1992, p. 24).

Desse modo, longe de ser o desdobramento da questão "como é feito $O$ Mestre $e$ Margarida?", podemos ver como é o poder de Woland que dá conta de pensar a relação entre a narrativa soviética e o romance dentro do romance: é por seus poderes que o romance do Mestre aparece e ressurge escatológica e satiricamente. Essa onipotência de deus ex machina de Woland tem como finalidade a provocação de Bulgákov de explorar os limites das situações dialógicas quanto a noções como verdade, responsabilidade e poder em todos os níveis narrativos do romance. Ao invés de um personagem-narrador que organiza a realidade de seu sonho, como em "As aventuras de Tchítchikov", nos deparamos aqui com Woland organizando e determinando a realidade da narrativa que se passa em Jerusalém: o autor dela, ao contrário do narrador de "As aventuras", não tem esse poder. E vimos como o mais trágico da narrativa talvez seja exatamente isto: as situações dialogais parresiásticas só podem surgir por meio de um ato que é ao mesmo tempo fantástico e contraditoriamente oriundo de um poder onipotente que suplanta o poder soviético oficial.

Isso significa que Bulgákov não busca adequar-se a Goethe nos termos de Barratt, como se a literatura "periférica" buscasse se adequar à forma da literatura da metrópole. Podendo ser encontrada a paródia como "canto ao lado de" também em Goethe, o procedimento de Bulgákov em relação a Goethe é semelhante do em relação a Gógol: parodiar a paródia, sendo o Goethe de seu tempo, e ampliando os cantos que canta junto, mixando um com o outro.

Um exemplo disso é a epígrafe goethiana na obra de Bulgákov: "Mas quem é você, afinal? - Sou parte da força que quer sempre o mal mas sempre faz o bem" (BULGÁKOV, 1992, p. 10). A fala do Mefisto goethiano é propositalmente descontextualizada e 
recontextualizada para fazer soar o ambiente cultural russo de fin de siècle e, com isso, tematizar a contradição de formas.

Nesse sentido, vale a pena perguntar qual a relação de $O$ Mestre e Margarida com o modernismo. Ao permanecer ambígua e aberta, na obra não há um julgamento da modernidade em Bulgákov, porque um tal julgamento não teria o menor sentido. Há, sim, um julgamento de determinada interpretação da modernidade, e a veiculação de uma outra. A argumentação contra a ideia de que Bulgákov se voltaria totalmente contra a modernidade segue próxima àquela contra os que o consideravam um crítico da Revolução, como ele diz em carta ao alto escalão do Partido: "Um pasquim contra a revolução por vários motivos, dos quais, por falta de espaço, assinalo apenas um: um pasquim contra a revolução, devido à extraordinária grandiosidade desta, é IMPOSSÍVEL de ser escrito" (ANDRADE, 2002, p. 140). Não é da Revolução que ele é crítico, mas de certa apropriação desta; não é da modernidade que Bulgákov é crítico, mas de certa interpretação do que ela seja.

Talvez possamos pensar o tipo de paródia de que Bulgákov faz uso como uma técnica especial de representação do real em relação com o modernismo. A paródia como canto ao lado de em Bulgákov acaba levando a uma espécie de pastiche que reproduz e produz efeitos traumáticos, como a rejeição de publicação por órgãos oficiais e a detração pública por parte dos críticos. Uma repetição que produz a si mesma: a paródia como repetição de Fausto em jogo ao lado da paródia como repetição de outros textos como método não do simulacro como fuga do real, mas da irrupção do real em seu aspecto mais traumático. Na atualização do método de representação do realismo "crítico" que se abre para a fantasia satírica - e em outros textos para a ficção científica satírica - podemos ver um duplo movimento em relação ao real. Por um lado, uma evasão do real nessa abertura ao fantástico; por outro, justamente uma abertura para o real enquanto trauma. A entrada de Woland é, ao mesmo tempo, uma fuga do real e o evento que revela o aspecto traumático do real: a corrida de Ivan atrás dos personagens diabólicos como experiência traumática de uma abertura ao real, atitude que só poderia ser constatada como esquizofrenia para a experiência do real administrado e normalizado. Assim, ao "fugir" do real, a prosa de Bulgákov acaba por expô-lo, revelando o automatismo do real administrado por meio de seu transbordamento. 
Essas reflexões se devem à análise de Hal Foster do "retorno do real" executado por meio das repetições de Andy Warhol, já que me interessa o percurso do seu pensamento que procura ver no simulacro o referencial, na complacência, a crítica ${ }^{52}$ (FOSTER, 2013, p. 125):

Se você não pode derrotá-los, sugere, Warhol, junte-se a eles. Mais: se você entrar totalmente no jogo, acabará por expô-lo; ou seja, revelar o automatismo e até o autismo desse processo, por meio de seu próprio exemplo excessivo. [...] Antes de mais nada, as repetições de Warhol não só reproduzem efeitos traumáticos; também os produzem. Portanto, várias coisas contraditórias ocorrem ao mesmo tempo nessas repetições: uma evasão do significado traumático e uma abertura para ele, uma defesa contra o afeto traumático e sua produção. (FOSTER, 2013, p. 126-7).

Foster pensa o procedimento estético de Warhol a partir dos seminários de Lacan de 1960, que procuram pensar "o real em termos de trauma", e aqui incorporamos algumas sugestões de Foster que se adequam a Bulgákov, vendo a conexão íntima disso com o procedimento paródico, que, no entanto, não é analisado por Foster. Como em Warhol, a repetição paródica em Bulgákov transcende a sátira individualizada, apontando para o caráter sistemático das forças que geram o trauma do real e o administram.

Por um lado, a paródia esvazia o sentido e rompe com o jogo da representação, enquanto por outro, ela protege o real apontando para ele, rompendo o anteparo do parodiado. Ou seja, não é tanto o referente da representação o que está em jogo quando Bulgákov "representa" a realidade soviética, por exemplo, na conversa do lago do Patriarca entre Berlioz e Biezdomni, mas uma proteção do real enquanto traumático - que, aliás, se antecipa, por exemplo, no malestar de Berlioz ao ver um cidadão transparente se balançar no ar.

A barreira de Berlioz em relação ao fantástico é, ao mesmo tempo, a barreira perante o trauma do real. Foster escreve que "o hiper-realismo tem a ver com esse real que está embaixo, mas, como hiper-realismo, está interessado em ficar em cima, deixar o real embaixo. Ao contrário do surrealismo, portanto, o hiper-realismo quer antes ocultar que revelar esse real"

\footnotetext{
${ }^{52}$ Se Foster está pensando na possível "pequena perturbação do espetáculo capitalista que ela [a ruptura] pode produzir" (FOSTER, 2013, p. 140), estamos aqui pensando na "pequena perturbação" do espetáculo do realismo socialista. A transposição dos problemas do mundo capitalista do pós-guerra para o soviético das décadas de 1920 e 1930 é complexa e exigiria um cuidado muito maior, de modo que com esse diálogo com Foster não estou sugerindo aqui um paralelo ou uma relação diretos entre um contexto histórico-social e outro: a relação é esfumaçada e se fundamenta na medida em que Foster utiliza elementos das vanguardas modernas - estas, sim, contemporâneas a Bulgákov - para propor seu pensamento do "retorno do real" em Warhol. Talvez uma possibilidade de compreensão do porquê ter sido possível realizar essa aproximação resida no caráter repetitivo do realismo socialista como literatura de propaganda e na instauração do desejo na imagem de um comunismo e do novo homem por vir. Outra possibilidade (que não exclui a primeira) é a de perceber a convergência de métodos de representação do real (e de relação com o real) e perceber as contingências do significado desses métodos em cada contexto histórico-social.
} 
(FOSTER, 2013, p. 139). Podemos pensar que a contraposição entre a atualização do realismo "crítico" em termos de fantástico satírico e o simbolismo vanguardista se contrapõe do mesmo modo em relação ao realismo socialista: enquanto um quer ocultar o real traumático caindo em um hiper- ou super-realismo do real superficial, o outro repete o real superficial em busca da experiência traumática do real (o sub-real). E é a partir dela que a prosa de Bulgákov se abre para o filosófico, podendo pôr em questão até mesmo os pressupostos dessa noção inquestionada de real de Foster.

$* *$

O próprio Mestre (que até 1934 ainda se chamava Fausto) é quem mais se feriu com o sub-real: aventurar-se na literatura após ter ganhado na loteria fez o agora nominado Mestre conhecer o lado oficial da realidade moscovita que o destrói, porque seus valores - de merecimento e verdade - não eram os mesmos que o do editor-chefe - o da adequação ideológica.

Em tom de reportagem oficial - do tipo que Ivan queria fazer do professor de magia negra: "prosseguiu ele [...]", "através da narrativa do visitante [...]", "Ivan soube que o Mestre e a desconhecida [...]”, “...depois de ganhar os cem mil, o misterioso visitante de Ivan fez o seguinte [...]”, "de acordo com ele, passaram-se apenas dois dias [...]”, (BULGÁKOV, 1992, p. 151 e ss.) -, ficamos sabendo da vida isolada do Mestre, o homem do subsolo soviético, sua postura de ermitão que metaforicamente viverá nas montanhas, longe dos acontecimentos sociais, como Zaratustra. A diferença é que, com sua produção intelectual, não visa a modificar substancialmente o povo, mas apenas aparentemente publicar o resultado de seus estudos. E, apesar de estar seguro quanto à qualidade formal e à verdade do que foi escrito, é impedido de publicá-lo, por uma instância institucionalizada que considera seu conteúdo inconveniente e se utiliza de meios escusos para criticar a obra (que não havia sido publicada) e seu autor. Temos, a partir daí, um relato romantizado e mitologizado da dificuldade de ser um escritor não alinhado no período stalinista.

A experiência traumática desse homem-do-subsolo-zaratustra-fausto tem seu ápice na perda de seu nome original e na adoção de seu nome mítico. Como nenhum outro Fausto - e contrário aos ensinamentos de Zaratustra - O Mestre e Margarida é permeado por um sentimento de vingança fantástica, seja pelas mãos de Margarida, tornada bruxa que destrói o apartamento do crítico que detratou publicamente o romance do Mestre, seja por mãos dos sequazes diabólicos que escracham desde restaurantes e lojas finos até pequenos detentores do 
poder, como zeladores e polícia. A extensão dessas situações de escracho ao mesmo tempo vinga fantasticamente e repete traumaticamente o real, ao expor à exaustão a injustiça da vida soviética. Se Strada e outros afirmam que Woland foi a Moscou para recuperar o romance do Mestre é porque deixam de lado a vingança ficcional exaustiva que o gênio do mal promove, que extrapola em intensidade a executada por Pilatos no romance. É essa dimensão do mal e que pensa a justiça a partir da moralidade, e que, inclusive, promove o aniquilamento daqueles que impediram o estabelecimento de um campo ético, a contradição ("o mal que faz o bem") e o lado trágico da afirmação do ético em $O$ Mestre e Margarida.

Uma primeira explicação para o papel incomum de Margarida ocorre por meio da compreensão do forte significado do feminino na cultura russa (sendo esse, inclusive, um dos panos de fundo da noção de Sofia de Soloviov). Tal significado podemos vislumbrar na tradição de representação da mulher russa de A filha do capitão (1836), de Púchkin, à Ana Kariênina (1877), de Tolstói, e Depois do teatro (1892), de Tchékhov. Ela está refletida e atuante na separação de Margarida de seu rico marido e no seu papel ativo no pacto fáustico.

É na cena do pacto - ou daquilo que deveria ser um pacto - que podemos ver de maneira mais nítida o destino e o papel de Margarida no romance. Dele é retirado todo o elemento trágico da decisão e ponderação do pactário ${ }^{53}$. É justamente nesse aspecto trágico que parece se basear, por exemplo, a trama de Grande Sertão: veredas (1956), romance no qual esse momento é elevado a uma espécie de lugar central da narrativa, a ponto de podermos até mesmo falar que a obra só existe porque narrada por alguém que, no fundo, está interessado em saber se fez ou não fez o pacto, se o demônio existe ou não existe. São essas duas questões que constituem o ponto central e decisivo das preocupações do narrador em primeira pessoa, e que são as motivadoras do relato que acompanhamos durante todo o romance de Guimarães Rosa.

Aqui, em Bulgákov, o pacto é, no entanto, firmado de modo simples e decidido, em nome do amor de Margarida pelo Mestre, quase como se não fosse um pacto. Vale lembrar que

\footnotetext{
${ }^{53}$ Ver (DABEZIES, 1972, p. 193), ao abordar a personagem Margarida na obra de Bulgákov: "Quanto ao pacto, ele perdeu consideravelmente seu valor trágico". É nessa obra também que vemos sugerida a importância de Margarida do ponto de vista do fáustico no romance de Bulgákov. Veja: "Mais importante, os protagonistas humanos trocaram, por assim dizer, seus papéis e a desenvoltura do procedimento sublinha quanto Bulgákov parodia Goethe - ou principalmente Gounod [.] [...] É, com efeito, Margarida quem assume aqui o papel clássico de Fausto. É a ela que o diabo se dirige, é ela que, rejuvenescida, desaparece no sabbat, é ela a insatisfeita, a voluntária que 'nada atormenta', e que cai nas mesquinharias da humanidade média". (Tradução nossa).
} 
no original goethiano também não se pode dar estatuto completo de pacto ao trato entre Mefistófeles e Fausto e entre o primeiro e deus: não se trata bem de um pacto, mas de apostas, de uma relação lúdica, tanto entre deus e o diabo, como entre Mefistófeles e Fausto. Aqui, a possibilidade de existência do ser fantástico é assumida desde o primeiro momento pela pactária, sendo as consequências da sua existência no interior de uma sociedade com determinada visão de mundo o centro da trama do romance.

$\mathrm{Na}$ verdade, parece haver uma diferença fundamental entre, por um lado, Margarida - a pactuária, em certo sentido - e o Mestre e, por outro, os outros personagens moscovitas atormentados pela presença da trupe diabólica. Os primeiros afirmam compreender e adivinhar o que está se passando, tal como podemos perceber pela fala de Margarida, a mesma na qual afirma que aceita o negócio sórdido em que se viu envolvida apenas por conta do amor, o que será analisado posteriormente: "Não, espere... Sei o que estou fazendo. Concordo com tudo por causa dele” e, pouco depois, “- Oh, não! - exclamou Margarida, surpreendendo os transeuntes - concordo com tudo, tudo mesmo, concordo em executar essa comédia com o unguento, concordo em ir para o diabo" (BULGÁKOV, 1992, p. 249). Também o Mestre, quando ouve o relato da história de Ivan, afirma: “mas como adivinhei tudo! Como adivinhei!” (BULGÁKOV, 1992, p. 149), e logo a seguir introduz a ideia de que aqueles que fossem versados em literatura logo conheceriam ou adivinhariam do que se tratava:

- Logo no início da sua descrição - prosseguiu o visitante - adivinhei com quem teve o prazer de conversar ontem. Dou-lhe minha palavra. Bem, o senhor é certamente leigo no assunto [...], mas Berlioz, que eu saiba, tinha lido alguma coisa! As primeiras palavras desse professor bastaram para dissipar todas as minhas dúvidas. Era impossível deixar de reconhecê-lo, meu amigo! Aliás, o senhor... o senhor vai me desculpar, mas se não me engano, é ignorante no assunto. (BULGÁKOV, 1992, p. 150).

Com isso, são desenvolvidos dois temas próprios ao romance de Bulgákov em relação às outras obras de caráter fáustico acima citadas. Por um lado, é estabelecido um claro desenvolvimento histórico da forma fáustica que não parece haver em Goethe. A circularidade temporal da visita demoníaca à Terra, como uma olimpíada que acontece regularmente em determinado período, a cada vez em um lugar diferente do globo, faz com que se estabeleçam parâmetros para esse acontecimento. Em outras palavras, há formas ou arquétipos fáusticos. Mas, assim como nas Olimpíadas, em que cada partida ou competição é única e possui sua própria história, o mesmo se dá em cada novo aparecimento das forças malignas entre os humanos. A questão da historicidade é, desse modo, colocada até mesmo no nível do 
desenvolvimento formal do romance, surgindo através do seu próprio 'conteúdo', a partir do qual essa questão pode ser abstraída ${ }^{54}$.

Por outro lado, o conhecimento que distingue o Mestre e a Margarida dos outros personagens moscovitas reside em certo capital cultural ou formação cultural, em certo estatuto de classe, oriundo da vivência prática com a literatura, a ópera etc. É apenas no capítulo 13, "Aparece o herói”, que temos a confirmação, no nível da realidade do romance, de que a pessoa humana era o Satanás. Já no capítulo 15, "O sonho de Nicanor Ivanovitch", Bossoi, o "síndico" (personagem de especial interesse para Bulgákov, talvez por representar os abusos cotidianos dos que detêm um pequeno poder), após ser preso e vítima do conflito entre realidades e ficção, sonha, já no sanatório, sobre uma peça de Púchkin. Aqui, além de um momento sui generis de imbricação entre realidades e ficções (entre sonho e arte), encontramos mais um exemplo do valor do conhecimento meramente formal do literário - o nome de Púchkin -, em oposição ao conhecimento mesmo de suas obras, capaz de comover, ou seja, de atenuar e se efetivar na realidade (do sonho):

\begin{abstract}
Antes deste seu sonho, Nicanor Ivanovitch não conhecia absolutamente as obras de Puchkin, mas conhecia muito bem o poeta de nome, e todos os dias pronunciava várias vezes frases do tipo: "E o aluguel da casa, quem é que vai pagar? Púchkin? Ou "Portanto, foi Púchkin quem tirou a lâmpada lá na escada?", e ainda "E quem vai comprar o petróleo, Púchkin por acaso?".

Agora, depois de tomar conhecimento de uma de suas obras, Nicanor Ivanovitch ficou triste; imaginou a mulher de joelhos, com os órfãos, exposta à chuva, e pensou involuntariamente: "Mas que tipo horrível é esse Kuroliessov!”. (BULGÁKOV, 1992, p. 182).
\end{abstract}

Trata-se, é claro, de mais uma característica da própria economia do romance que reforça a importância da ligação com um outro mundo, uma outra realidade, dando-lhe um papel significativo na sua estrutura, a qual vem reforçada por algumas características, por exemplo, de Margarida: tinha dinheiro suficiente a ponto de não se preocupar com ele, vestiase bem a ponto de ser observada e se distinguir em meio à multidão.

E uma das mudanças que esses dois modos particulares de apropriação do elemento fáustico em $O$ Mestre e Margarida acarretam pode ser encontrada justamente na forma como o pacto se dá:

\footnotetext{
${ }^{54}$ Nesse sentido, O Mestre e Margarida e o Meu Fausto de Valéry voltam a se aproximar, já que este último também se baseia em que Fausto tenha lido tudo que se escreveu sobre ele e saiba de antemão como se portar perante o diabo que, como aponta Kittler em Aufschreibesysteme 1800/1900 (1985), está obsoleto em relação não apenas às novas tecnologias, mas ao próprio sistema de inscrição e de pensamento do homem do Aufschreibesysteme 1900.
} 
Já existe a tradição [...] de acordo com a qual a anfitriã do baile deve ter obrigatoriamente o nome de Margarida. Isto, em primeiro lugar; em segundo lugar, ela deve ser nativa da terra. E, como a senhora vê, nós estamos viajando e no presente momento encontramo-nos em Moscou. (BULGÁKOV, 1992, p. 276).

É no primeiro capítulo da segunda parte, "Margarida", que Margarida Nicolaievna é descrita por "um narrador veraz mas uma pessoa estranha" que sente "um aperto no coração" (BULGÁKOV, 1992, p. 238) por sua personagem. Em uma construção fatalista um tanto circense e operística, com antecipações mágicas, em sonho e em pequenos indícios no decorrer do dia - tal como ocorrera com Berlioz, parece ser esse, portanto, o procedimento padrão do demoníaco nessa sua passagem pelos afazeres humanos -, esse narrador, que ora fala de si, ora faz um comentário espirituoso, no melhor estilo gogoliano de Almas mortas, relata o dia decisivo em que Margarida Nicolaievna se alça à Margarida enquanto arquétipo fáustico. Margarida Nicolaievna é a cidadã moscovita que se torna a Margarida fáustica (ou “margarítica"?) por meio de um conjunto misto de ações autoconscientes e fatalistas.

É apenas ao entender o que quer o segundo desconhecido que vem lhe falar - porque ele cita um trecho do romance do Mestre, como se fosse uma senha, que identifica que ambos compartilham um segredo em comum, algo extraoficial -, que ela compreende os indícios do acontecimento extraordinário que rondavam aquele dia e que a envolviam diretamente. Assim, aceita qualquer torpeza que a relação com esse cidadão desconhecido e seus superiores possa acarretar a ela. $\mathrm{O}$ fato de dizer que o faz unicamente em nome do amor é mais um indício de que ela sabe do que se trata - se resguardar de sua aceitação de participar de algo torpe por fazêlo em nome de algo superior. Essa sua sabedoria também indica, além disso, que há ali um acontecimento que não é determinado pelos arquétipos goethianos, mas que se constrói na relação lúdica tensa entre suas vontades e as da trupe maligna.

Está em jogo, nesse momento, a adequação a uma forma, no sentido do cumprimento ou não de condições suficientes, ou seja, de regras, para que o jogo fáustico se dê, para que as situações presentes no romance sejam vistas desde o prisma das questões mobilizadas no âmbito do arquétipo fáustico. É nesse sentido que chamamos essa interação entre Margarida e Azzazelo de pacto, uma vez que esse nome estabelece um momento fundamental nesse jogo, tal como as quatro linhas de uma quadra estabelecem os limites da área de jogo, o gol o objetivo, e a bola o objeto de jogo. Ou seja, chamamos primeiramente de pacto o que ocorre aqui entre Margarida e Azzazelo, querendo indicar, com isso, que estamos em solo arquetípico faustiano. 
E é o prosseguimento do que acontece a partir desse terreno comum estabelecido entre certa tradição arquetípica e essa 'nova' obra o que está em jogo: para que lado aponta a reutilização dessas peças fáusticas, que tipo de coisa é construída a partir desses destroços, como esse modelo é desafiado no romance? É ele jogado de tal forma a superar as regras do jogo dadas até então? Ou seja, será que, no decurso do jogado, o próprio arquétipo fáustico - o terreno, o âmbito - é transformado em sua raiz (e é bom que se fale em transformação, e não em inversão, como se o que não se encaixa no anterior, fosse necessariamente o seu oposto)?

Que sejam Margarida e Azzazelo os jogadores, os atores desse espaço lúdico, não deve ser visto como constituindo um problema formal no que diz respeito ao modo como entendemos esse jogo: ou seja, como fáustico. Igualmente, que o pacto aconteça de um modo diferente do arquétipo goethiano, tampouco é motivo para negarmos haver nessa relação o estabelecimento desse âmbito, desse terreno lúdico ou fáustico, por meio do qual podemos entender o romance dentro da tradição fáustica.

No entanto, as diferenças são específicas e particulares do romance de Bulgákov, e são, por sua vez, indícios do lugar e do tempo em que essa partida fáustica se dá. Lugar e tempo - a Moscou soviética da década de 1930 - nada mais são, em certo sentido, do que um aspecto determinante da realidade que dissemos ser o intuito de Bulgákov retratar. Por um lado, nos deparamos com uma forma, um arquétipo, regras, enfim, um âmbito, que restringem o romance (tal como se Bulgákov se obrigasse a escrever um poema com tantos versos e determinadas rimas); por outro, com uma realidade, um 'conteúdo' ao qual essa forma tem que se adequar e que a desafia. Topamos aqui com uma contradição oriunda da atualização de certa forma literária, ou de determinadas leis do jogo literário.

Esta atualização, ou realização de certa forma que não pode se dar, ocorre ao ser colocada frente a frente com a realidade ou conteúdo ao qual será 'aplicada'. Podemos dizer que é o embate entre estes conteúdos - o atualizado e o já presente - que gera a fragmentação do romance em romances, e faz com que não possamos identificar claramente os arquétipos faustianos em um ou outro personagem. Os aspectos determinantes e característicos do arquétipo do personagem Fausto, por exemplo, podem ser igualmente encontrados no Mestre, na Margarida, em Biezdomni e - em certo sentido, até mesmo em Jeshua e Pôncio Pilatos.

Isso leva o leitor a compreender o conteúdo de $O$ Mestre e Margarida como fáustico. $\mathrm{O}$ papel de Woland no romance reside, sob esse ponto de vista, não apenas em embaralhar ficção e realidade na realidade soviética, mas principalmente em dotar tal realidade soviética dos contornos da realidade fáustica. Esses contornos são estabelecidos, no entanto, na forma de uma 
questão daquilo que é, na verdade, um dos objetos das questões mais antigas e tradicionais da história da filosofia e que se constitui como a questão determinante do fazer literário: o homem. Tal questão surge agora no conteúdo do romance de maneira consciente.

Nesse sentido, vale a pena pôr em evidência quase em sua integridade as palavras de Rosenfeld sobre o pertencimento de Kafka a seu tempo, trazendo à tona o contexto do desenvolvimento da técnica moderna e a modificação na natureza do homem ele mesmo, o qual é visto como a própria realidade do romancista e, principalmente, do romancista deste tempo, que é também o nosso. Essas palavras vigoram também para Bulgákov, com a ressalva de que, em Bulgákov, isso se dá ainda em um nível meta, na medida em que o romance é uma tomada de consciência dessa questão como de si mesmo e de sua forma - consciência da forma:

[...] pode-se dizer mesmo que o próprio Kafka já é parte e resultado da revolução das artes que se iniciou nos fins do século passado. É uma revolução que continua até hoje a abalar os fundamentos não só do romance, mas também do teatro, das artes plásticas e da música. De modo que Kafka já está dentro de um processo que se inicia antes de ele ter começado a escrever. Podemos dizer que faz parte da revolução geral em que se encontram as artes no nosso século, revolução esta que se iniciou por volta de 1890. Essa revolução, por sua vez, é sintoma do esforço de assimilar, de um outro modo, um novo sentimento de vida, uma nova realidade, uma nova concepção de homem. Com efeito, toda a concepção do homem, toda a visão da realidade se modificaram em virtude das várias revoluções industriais que eclodiram desde os fins do século XVIII e que se vêm repetindo, levando à industrialização acelerada e à tecnização do nosso mundo, criando uma nova realidade social e, por assim dizer, uma nova natureza [...]. (ROSENFELD, 1994, p. 42-3).

Se é Woland quem coloca a questão do novo homem em seu show de magia negra no Teatro de Variedades - “[...] será que esses cidadãos mudaram no seu íntimo?” (BULGÁKOV, 1992, p. 135) -, não à toa é ele também quem alude a Kant em sua conversa erudita com o crítico de arte. É que ele, como veiculador do pensamento crítico no interior do romance, parece sugerir com isso a procedência de suas dúvidas filosóficas: isso porque, ao mesmo tempo em que essa questão é uma das mais antigas em filosofia, ela instaura, em sua forma moderna com o filósofo de Königsberg -, um terreno completamente novo e próprio, tal como aponta Foucault em As palavras e as coisas: "o homem não é o mais velho problema nem o mais constante que se tenha colocado ao saber humano" (FOUCAULT, 2007, p. 536). No que tange à contradição desta afirmação com as reflexões sobre o conteúdo da literatura para Rosenfeld, elas evidenciam apenas como Rosenfeld é um homem de seu tempo e dos autores que analisamos - Kafka e Bulgákov. Mas Rosenfeld não parece se distanciar de seu próprio discurso 
e perceber o quanto ele também está conformado pelo seu tempo: já em O Mestre e Margarida, devido à introdução dos arquétipos fáusticos, já podemos enxergar um posicionamento crítico e distanciado em relação ao seu próprio tempo.

Alude-se a Kant, no romance, no interior do debate sobre a existência ou não de deus: ele teria forjado uma nova prova após ter rejeitado todas as cinco da tradição - que remonta a Tomás de Aquino ao inaugurar uma aproximação entre fé e razão na história da filosofia ocidental. O interessante, aqui, é perceber como Berlioz, ao rejeitar a prova de Kant, age como um dogmático, enquanto Woland, sendo quem é e ao propor com sua própria existência uma nova prova da existência de deus, atua como um cético. Parte de sua prova é a narrativa sobre Pôncio Pilatos que sai de sua boca naquela tarde na Praça do Patriarca: ou seja, é a própria explosão ou fragmentação da forma do romance em diferentes romances, espaços e temporalidades (que, no entanto, miticamente se repetem, como as olimpíadas modernas). Essa ambiguidade de Woland - tão de acordo com o Mefisto goethiano e com a epígrafe de $O$ Mestre e Margarida oriunda de sua apresentação a Fausto - ecoa a própria ambiguidade de Kant com essa questão, tal como indica Lebrun em seu ensaio denominado "A aporética da coisa em si" (LEBRUN, 2012). É da não resolução de Kant da questão da existência de deus, ao colocá-la em um terreno de jogo invertido em relação aos seus colegas metafísicos anteriores, que emerge a questão do homem e que pôde se desenvolver toda uma vasta literatura no decorrer do século XIX sobre o niilismo.

A prova da existência de deus dada por Woland - a decapitação de Berlioz - não é nenhuma prova no sentido usual do termo, nem mesmo para a economia do romance, cujo capítulo "A sétima prova" é imediatamente posterior à narrativa do encontro entre Jeshua e Pôncio Pilatos. Contudo, em um determinado nível de leitura do romance, o narrado por Woland instaura a questão da interpretação do passado histórico - de modo não desconectado da literária ou ficcional: Berlioz e Woland contam versões interpretativas de um evento histórico que teria acontecido no mesmo período do ano em que estão conversando. Isso aponta tanto para a possibilidade de se compreender as Críticas de Kant (e com isso, no limite, todos os textos filosóficos) como fáusticos, quanto para uma situação em que, no limite, a verdade da existência ou da não existência de deus pode ser decidida apenas por meio do homem. Um homem para quem a verdade histórica e a ficcional estão embaralhadas. É justamente aí que podemos entender um dos níveis de hermeneuticidade do romance, e também de colocação em questão, com tal nível, do humano. 
Não seria isso que opera a epígrafe faustiana de O Mestre e Margarida, citada do Fausto de Goethe? É claro que, no entanto, essa epígrafe 'erudita' pode ser, por sua vez, apenas uma brincadeira, sendo somente uma citação do grande Goethe visando atrair a atenção do leitor; sem dúvida atrai, o que não impede a reflexão a respeito desta - e não de outra - escolha para o jogo de epígrafes. Também no Fausto, se pode ser uma mera frase jogral de Mefisto, é a primeira, contudo, com a qual tal personagem se apresenta, mesmo que paradoxalmente, aludindo a um jogo que diz mais do que aparentemente está dito e menos do que uma grande elucubração pode fazer significar.

O creme de Azazello, o objeto que garantiu o selamento e a existência do pacto, leva Margarida a se transformar em uma bruxa invisível e destruidora. Esse episódio de destruição e aniquilamento não encontra semelhanças nos Faustos anteriores: ele parece a expressão fantástica do ego ferido do homem do subsolo, tal como as aventuras narradas pelo personagem dostoievskiano na segunda metade de Memórias do subsolo (1864).

Em certa medida, Margarida também é um Homem do subsolo que, com o creme de Azazello, torna-se um homem de ação: ela não esbarra no crítico que destruiu a vida de seu amante durante o footing na Perspectiva Niévski, mas destrói escatologicamente seu "espaço vital”. É verdade, no entanto, que isso, no nível da vida propriamente dita de Bulgákov, se dá no âmbito da ficção.

Ocorre que, formalmente, o elemento fáustico é decisivo para a compreensão do romance $O$ Mestre e Margarida, o que já está prenunciado em sua epígrafe ${ }^{55}$. Esta aponta, desde o início do romance, para uma centralidade do ‘tom’ fáustico nele presente. A tonalidade fáustica da obra consiste na temática geral em que ela está inserida - o conflito que dá origem e constitui a modernidade, assim como no qual ela culmina, o entre homem e deus. O que está em jogo em $O$ Mestre e Margarida do ponto de vista da chave fáustica que o constitui é a modernidade entendida em seus múltiplos conflitos e atualizada a cada visita do dito-cujo.

A realidade da qual a atividade artístico-literária de Bulgákov parte é bastante particular na história da humanidade: a década soviética de 1930. É importante observar que a chave fáustica muito mais coloca em evidência os conflitos da modernidade presentes nessa realidade do que os resolve. A crítica ao "mundo soviético" não significa uma rejeição desse mundo, mas uma relação ambígua e crítica com ele; do mesmo modo, a 'existência' real do fantástico no nível da realidade do romance não pode ser vista como um atestado do irracionalismo ou do misticismo de seu autor, mas sim como uma ponderação sobre o ser real e ficcional.

\footnotetext{
${ }^{55}$ Parte desta seção foi desenvolvida e publicada em forma de artigo na revista Ipseitas (PHILIPSON, 2015).
} 
O ponto central do romance, a contradição em torno da qual ele se ergue, é dado pela fala de Woland no baile moscovita: será que os homens mudaram em seu íntimo? É a essência do humano o que está em jogo na partida fáustica constituinte do romance, em seus diversos níveis de realidade e em suas diversas tramas. A batalha em torno do que é a essência do humano assume na obra, no entanto, significados característicos. Não se trata de dizer se o homem seria bom ou mal por natureza - o homem é o que é, apenas um pouco pior por causa do problema de moradia -, mas sim se aquilo que faz do homem homem seria apenas a razão, e, se sim, que razão afinal seria essa. Trata-se, assim, de encontrar um lugar relevante para a fantasia na constituição do ser humano - e, por consequência, da literatura e da arte. Assim, a questão da existência de deus está imbricada com a questão da existência de alguma instância para além da racionalidade reificada. Desse modo, o mal faz o bem, como diz a epígrafe goethiana do romance, porque um mundo sem sombras (fantasia) não seria um mundo em que o bem (razão) triunfaria. 


\section{Jesus-rebus-Pilatos: a questão do real pela polifonia de métodos de representação}

Nur wenn es Film wäre, würde ich das alles für wahr halten. (HERZOG, 2009 , p. 9) ${ }^{56}$

O trecho acima é de Caminhando no gelo (1978), diário - que foi publicado com algumas modificações - do diretor de cinema Werner Herzog. Ele está logo no início de sua travessia de Munique a Paris em 1974, iniciada ao receber por telefone a notícia de que Lotte Eisner, a crítica de cinema que apostou nele e na sua geração de cineastas alemães, estava com câncer, e pode nos ajudar a introduzir as questões que gostaria de tratar neste capítulo.

Talvez a central delas seja a da relação entre verdade e ficção, que é tematizada em $O$ Mestre e Margarida justamente a respeito do romance de Pilatos: em uma das versões de $O$ Mestre e Margarida, Woland teria dito ao Mestre que "em seu romance você escreveu a verdade. Tudo se passou exatamente como você falou" ${ }^{57}$. Já em uma passagem da versão final, no primeiro capítulo, já citada, essa ideia aparece modificada, a partir de uma associação entre realidade e fantasia, uma vez que a existência de Jesus ocorrerá presentemente (no presente dos personagens) ao se virar o capítulo e entrar no romance (já é um romance? talvez se apresente primeiramente como uma narrativa) escrito pelo Mestre e encarnado na realidade por Woland:

- Tenham em conta que Jesus existiu.

- Bem, professor - respondeu, Berlioz, sorrindo a contragosto - respeitamos os seus vastos conhecimentos, mas o nosso ponto de vista a este respeito é diferente.

- Não é preciso nenhum ponto de vista! - respondeu o estranho professor simplesmente ele existiu, e nada mais.

- Mas é preciso alguma prova... - ensaiou Berlioz.

- Não é preciso nenhuma prova - respondeu o professor [...]. (BULGÁKOV, 1992, p. 24).

Nessa narrativa-verdade, a própria verdade é tematizada, na seguinte fala de JeshuaJesus, em um momento central de sua trama que difere de todos os Evangelhos:

\footnotetext{
56 “Apenas se fosse um filme eu tomaria isso tudo como verdade.” (Tradução nossa. Na tradução brasileira da Paz e Terra perde-se a referência crucial ao verdadeiro: "Só acreditaria nisso se fosse um filme”, Cf. (HERZOG, 1982, p. 11)). Observação: vale notar um acontecimento insípido: na contracapa do livro com a versão traduzida presente na biblioteca da FFLCH, alguém escreveu: "Werner Herzog, the Master" ass: JR".
}

${ }^{57}$ Cf. (BARRATT, 1987, p. 248-9). 
- A verdade consiste primeiramente em que o senhor está com dor de cabeça, e essa dor é tão forte que o senhor pensa covardemente em morrer. O senhor não tem forças para falar comigo, nem sequer para me olhar. Sou agora involuntariamente o seu carrasco e isto me amargura. $\mathrm{O}$ senhor não pode sequer pensar em alguma coisa e deseja apenas que venha o seu cão, que parece ser a única criatura por quem nutre algum afeto. Mas os seus tormentos vão acabar agora mesmo, a dor de cabeça passará. (BULGÁKOV, 1992, p. $31)$.

A verdade está associada aqui não com algum milagre da natureza divina e extramundana de Jesus, mas com dor física e psicológica, amargura e sofrimento, coisas que são diretamente relacionadas no romance com as relações de poder do mundo romano contemporâneo à vida do assim chamado Jesus histórico.

A relação entre verdade, dor e narrativa também está presente em Caminhando no gelo. Herzog escreve o diário de sua caminhada de Munique a Paris como modo de não permitir que Eisnerin morra: “[...] Der Deutsche Film könne sie gerade jetzt noch nicht entbehren, wir dürften ihren Tod nicht zulassen. [...] Ich ging auf dem geradesten Weg nach Paris, in dem sicheren Glauben, sie werde am Leben bleiben, wenn ich zu Fuß käme" 58 (HERZOG, 2009, p. 5). E, um pouco mais adiante:

Ein einziger, alles beherrschender Gedanke: weg von hier... Die Menschen machen mir Angst. Die Eisnerin darf nicht sterben, sie wird nicht sterben, ich erlaube das nicht. Sie wird nicht sterben, sie wird nicht. Nicht jetzt, das darf sie nicht. Nein, jetzt stirbt sie nicht, weil sie nicht stirbt. Meine Schritte gehen fest. Und jetzt zittert die Erde. Wenn ich gehe, geht ein Bison. Wenn ich raste, ruht ein Berg. Wehe! Sie darf nicht. Sie wird nicht. Wenn ich in Paris bin, lebt sie. Es wird nicht anders sein, weil es nicht darf. Sie darf nicht sterben. Später vielleicht, wenn wir es erlauben. ${ }^{59}$ (HERZOG, 2009, p. 8).

"Wehe!" - ousar, mas que guarda proximidade também com a ideia de dor - e a morte fizeram com que Herzog tanto se pusesse a caminho, quanto escrevesse o diário dessa sua caminhada, um tipo de experiência catártica de cuidado da psique. Enquanto caminha e escreve seu diário, como um deus ex machina, o narrador em primeira pessoa decide que não haverá morte, e portanto não haverá dor, em uma espécie de ato performativo da linguagem muito

\footnotetext{
58 “[...] O cinema alemão ainda não pode prescindir dela, não devemos permitir sua morte. [...] Fui pelo caminho mais direto para Paris, convencido de que ela ficaria viva se eu chegasse a pé." (Tradução nossa).

59 “Um único pensamento predominava sobre todos os outros: ir embora daqui. Os seres humanos me dão medo. Eisnerin não pode morrer, não irá morrer, não vou permitir. Ela não vai morrer, não vai. Não agora, ela não pode. Não, ela não vai morrer agora simplesmente porque ela não vai morrer. Meus passos vão firmes. E agora a terra treme. Quando caminho, caminha um bisão. Quando descanso, repousa uma montanha. Ela que não ouse! Não vai. Quando eu estiver em Paris, ela estará vivendo. Não será diferente, porque não pode. Ela não pode morrer. Depois talvez, quando permitirmos." (Tradução nossa).
} 
semelhante ao de Woland, acima citado: Jesus existiu e não é preciso nenhuma prova para isso, basta instaurar uma realidade mais que real (uma espécie de cinema, podemos pensar?): vale notar que a narrativa valida a verdade do ato performativo da linguagem relacionada a alguma dor.

E isso porque não é apenas no romance dentro do romance que a dor psicológica aparece: o Mestre, embora não tenha escrito o seu romance a partir da experiência da dor, no momento em que o diabo aparece em Moscou, está sofrendo psicologicamente. E, em certa perspectiva, seria possível pensar na possibilidade de Woland não ser mesmo real, mas sim um alterego ficcional do próprio Mestre que vem para salvá-lo e dar-lhe descanso (como se o Mestre fosse o escritor do romance mesmo $O$ Mestre e Margarida). A fala de Woland seria, assim, em última instância, sua, na verdade - e talvez por isso Woland não diz mais para o Mestre que seu romance é a verdade, porque ele não precisa mesmo dizê-lo para si mesmo. Ainda que isso se mantenha somente uma possibilidade fraca de interpretação, podemos dizer sim que há alguma relação inexplicável entre a vinda de Woland e o resgate do Mestre (e de seu romance) e a maior evidência que temos é justamente a de que desde o primeiro acontecimento estranho em Moscou causado pela visita da trupe diabólica, aparece o romance queimado do Mestre, o que sugere uma noção de verdade bastante peculiar.

Nesse sentido, é também uma interpretação fraca extrapolar ainda mais, sugerindo que O Mestre e Margarida seria uma espécie de diário curativo de Bulgákov, que, não podendo ir para o exterior - como Herzog -, como tantas vezes tentou, escrevia não como fuga da realidade, já que vimos como seu romance está a todo momento respondendo à "realidade" e a seu tempo, mas como uma prática curativa psicológica. Não é possível justificar a contento essa interpretação, mas sendo possível sugeri-la, ela passa a acrescentar uma dimensão importante que perpassa o romance e que é tematizada, como vimos, no romance de Pilatos.

Essa prática curativa da escritura está relacionada à dor de uma perda, de uma ausência, da morte, de uma nostalgia de algo que passou. Vale trazer à luz que, porque em Marx "A história é um movimento em direção a um estado melhor, através de um avanço gradual e constante ou de eventuais transformações profundas", a nostalgia só poderia ser vista, diz Marcos P. Natali em A política da nostalgia, como "Falsa consciência e alienação, em última instância retirando o desejo pelo passado do espaço da possibilidade lógica e política" (NATALI, 2006, p. 60). O realismo socialista lato sensu, no entanto, logo após 1931, abandona a temporalidade homogeneizada, em que tudo é agora, rumo a "A new sense of the importance 
of history and genealogy" ${ }^{6}$ (CLARK, 2000, p. 136). Nessa mudança, a aparente fundação na teoria (marxista) se torna ainda mais aparente e superficial, segundo Clark, porque, nesse novo período, o realismo socialista ritualiza a história, deixando o terreno do real e indo parar no do fantástico.

Em $O$ Mestre e Margarida, passado, história, detração pública de um escritor e morte não são vistos nem a partir de Marx, como falsa consciência e alienação, nem como uma ritualização da cultura oficial stalinista (só são vistos como paródia, como vimos no primeiro capítulo). Além disso, se o Mestre pode ser visto como um personagem melancólico, a descrição de sua melancolia não se encaixa na conclusão de Natali de que

os melancólicos, então, são bastante lúcidos, reconhecendo a "realidade" da morte e evitando o divertissement de Pascal, aquela digressão elaborada para evitar que se pense na morte: ao se descobrirem incapazes de curar a morte, os homens teriam decidido não pensar nessas coisas. O melancólico, ao contrário, pensa nessas coisas - constantemente, obsessivamente -, mas conclui que de fato a morte e a perda são irreparáveis, para então ser, compreensivelmente, dominado pela tristeza. (NATALI, 2006, p. 72).

Isso porque o complexo procedimento paródico do romance impede até mesmo que a morte seja compreendida de fato como uma perda irreparável. A paródia do cogito cartesiano (bem apontada por Weir, 2002), na passagem em que Azazello mata o casal que dá nome ao romance, expõe bem como a morte não é sinônimo de dor aqui, mas de alívio e último escape da dor:

- Por que, Azazello, por quê? O que fez comigo?

Ela viu o Mestre que jazia ao lado, estremeceu e murmurou.

- Não esperava por isso... assassino!

- Mas não, não -respondeu Azazello - ele vai se levantar agora mesmo. Como está nervosa! [...]

- Ah, compreendo - disse o Mestre, ainda inquieto - você nos matou, nós estamos mortos. Mas que inteligente! Como é oportuno! Agora compreendi tudo.

- Ora, tenha paciência, é você quem está dizendo isso? - respondeu Azazello. - A sua companheira acaba de chamá-lo de Mestre; você consegue raciocinar; como pode estar morto, então? Será que para considerar-se vivo é preciso estar sentado obrigatoriamente num porão, vestindo um camisolão e ceroulas de hospital? Isso é ridículo! (BULGÁKOV, 1992, p. 401).

60 “Um novo sentido da importância da história e da genealogia.” (Tradução nossa). 
Enquanto para Descartes ao pensar, existe-se, o gênio maligno aqui é capaz não apenas de enganar o cogito a respeito até mesmo das verdades matemáticas, mas também em relação à existência enquanto vida oposta à morte. Mas não precisamos tirar daqui o misticismo de Bulgákov; podemos também ver nessa passagem como a questão da morte - enquanto a passagem do tempo que não volta, os acontecimentos que mudam para sempre a realidade, e a nostalgia resultante deste processo (principalmente quando as mudanças ocorrem muito rapidamente e têm ligação com a industrialização ${ }^{61}$ ) - recebe um tratamento bastante peculiar. Tal como Bieguemot diz sobre alguns escritores, como Dostoiévski, pode-se afirmar a imortalidade: “- Protesto! - exclamou calorosamente Bieguemot. - Dostoiévski é imortal!” (BULGÁKOV, 1992, p. 383).

Dostoiévski é imortal porque é um escritor, e não é uma carteirinha que faz do escritor escritor - basta tomar cinco páginas de um texto qualquer dele para o saber ${ }^{62}$, diz o personagem diabólico. Isso nos leva a pensar - com a ajuda de Weir, que analisa as noções de autoria que perpassam o romance de Bulgákov - que a nostalgia está associada em O Mestre e Margarida não com a melancolia de um passado que não volta, mas sim com a esquizofrenia ("Como já havíamos dito", nos lembra o narrador (BULGÁKOV, 1992) ligada à noção de autoria. Esquizofrenia porque pode até ser que se trate também de um passado que ficou para trás, mas apenas no sentido de que é um passado em que havia uma autocompreensão não fragmentária do self pela narrativa, de quando bastava escrever para que o escritor fosse escritor; "agora", o que afinal é ser escritor? O que afinal é uma narrativa? A identidade do escritor enquanto escritor e da narrativa enquanto narrativa - em suma, o A=A que sustentava a noção de autoria - está em questão e isso leva à experiência de dor psicológica, de uma aproximação entre nostalgia, melancolia e esquizofrenia:

[O Mestre e Margarida] does manage to reconfigure significantly the way fiction is used to interpret the self as author and inheritor of literary tradition. Whereas much of modernist fiction, and especially avantgard fiction, attempts to escape or overcome the literary past in parody or "trans-rational" language, The Master and Margarita uses the parodic structure to seek out equal ground

\footnotetext{
${ }^{61}$ M. Natali desenvolve toda uma genealogia da nostalgia, apontando como o termo, um neologismo, surgiu e se desenvolveu na esteira da modernidade e das revoluções tecnológicas, levando a transformações no campo e à migração massiva para as cidades; no caso de Bulgákov, a industrialização tem seu lugar em sua nostalgia, mas é claro que não é possível negligenciar as mudanças abruptas impostas pela Revolução, principalmente quanto ao que poderíamos chamar de o ambiente da tradição literária russa (moderna).

62 “Ora, será que para assegurar-se de que Dostoiévski é escritor seria preciso pedir-lhe um certificado? Tome cinco páginas quaisquer de um dos seus romances, e a senhora se certificará, sem qualquer cartão, que ele é um escritor." (BULGÁKOV, 1992, p. 383).
} 
on which to engage the past and preserve an open dialogue with it. ${ }^{63}$ (WEIR, 2002, p. 10).

Embora a experiência de dor presente em $O$ Mestre e Margarida não se adeque à conclusão de M. Natali, podemos sugerir, a partir desse comentário de Weir, que a "estrutura paródica" do romance é capaz sim de alcançar a lucidez obsessiva do melancólico sugerida pelo teórico brasileiro. Trata-se de uma lucidez obsessiva que, encontrando interditado o caminho até uma noção identitária de self, de autoria, é capaz de recusar tanto uma volta conservativa a qualquer custo ao passado, quanto as mazelas do presente - o caminhar a pé de Munique a Paris paralelamente a escrever o diário da viagem, de Herzog, e o "diálogo aberto" com o passado, de Bulgákov -, por meio da parodização como atividades terapêuticas, não no sentido de uma adequação à normalidade das convenções sociais nem de uma "fuga do real”, mas, em última instância, como uma investigação sobre a própria noção de verdade: "The Master and Margarita is consumed with this desire that art 'become knowledge', that literature reveal the truth." ${ }^{64}$ (WEIR, 2002, p. 3). Isso ocorre porque é a concepção de verdade que está por trás da questão da representação do real, o que parece ser algo tão óbvio e banal que quase nunca é posto como problema em estudos sobre realismo e fantasia em literatura.

Então, a questão da autoria como uma identidade do autor enquanto autor pelo conhecimento do passado em $O$ Mestre e Margarida, analisada por Weir, é um complexo processo nem tanto de busca pela verdade, como afirma, mas de busca pela verdade entendida mais precisamente como questionamento da noção mesma de verdade. E nem tanto de um ponto de vista lógico ou científico, mas principalmente ético-estético: Dostoiévski é um escritor porque qualquer cinco páginas de seu texto o atestam. Mas atestam o que exatamente? Talvez seu estilo estético e sua capacidade para responder à questão da autoria como a questão da verdade. Nesse sentido, então, poderíamos entender a noção de autoria como responsabilidade como faz o jovem Bakhtin, ou seja, como nexo entre arte e vida. A busca por autoria em Bulgákov é, assim, a busca pelo nexo entre essas duas instâncias. E o procedimento paródico da sátira menipeia pode ser visto como uma saída para a fragmentação do humano (da autoria) na modernidade, não como um modo de conservar a antiga noção de autoria e de verdade, mas

\footnotetext{
63 “[O Mestre e Margarida] é capaz de reconfigurar significativamente o modo como a ficção é usada para interpretar o self como autor e herdeiro da tradição literária. Enquanto boa parte da ficção modernista especialmente a vanguardista -, procura escapar da tradição literária ou superá-la por meio da paródia ou da linguagem 'transracional', $O$ Mestre e Margarida usa a estrutura paródica para buscar um terreno comum no qual possa engajar o passado e preservar com ele um diálogo aberto.” (Tradução nossa).

64 “O Mestre e Margarida é consumido pelo desejo de que a arte se torne 'conhecimento', de que a literatura revele a verdade." (Tradução nossa).
} 
sim como uma resposta que (re)instaura um nexo com a totalidade da cultura, que reinterpreta a essência do ser humano metalinguisticamente relativa a esse nexo, e não de modo relativizante ou niilista.

Nesse sentido, é sugestivo pensar no desenvolvimento do procedimento paródico de $O$ Mestre e Margarida como o desenvolvimento de uma técnica de transposição de mídias que preza pelo nexo entre arte e vida como responsabilidade e que, com isso, está pondo em questão a noção de verdade desde uma perspectiva ética e estético-literária. Diversamente da mimesis clássica, da tradução/traição, a paródia como uma transposição de mídias - embora tenha algo de semelhante com essas outras técnicas - é capaz de colocar no mesmo plano temporal e textual diversas temporalidades, mídias e coisas. Ela faz isso porque parte de uma concepção de linguagem - que Kittler entrevê no texto de Nietzsche, Verdade e mentira em sentido extramoral -, na qual "Sprache, von der Wahrsagerei moralischer, wenn nicht gar bildender Stimmen entkoppelt, ist nicht mehr Übersetzung vorsprachlicher Bedeutungen, sondern ein Medium unter Medien“ 65 (KITTLER, 2003, p. 226). Nessa concepção de linguagem, não é que a natureza (as coisas) e o espírito estejam em um continuum, como na teoria clássica da verdade como adequação da coisa ao sujeito, mas em choque. É a partir daí que Nietzsche pode falar que a verdade descreve apenas as relações das coisas com os humanos, e não algo imutável garantido pela ideia de deus ou pela hipótese kantiana necessária da coisa em si. Contudo, ao contrário de Nietzsche que, ao constatar tal verdade sobre a verdade, vai parar na instauração da pura diferencialidade ${ }^{66}$ entre a linguagem e as coisas, entre o lugar de fala e a verossimilhança do discurso, Bulgákov pode estar buscando o meio textual em que a verdade seja a responsável por algo, ou seja, em que a verdade vigore como um nexo entre as coisas e a linguagem, e entre linguagem e poder.

Talvez precisamente por isso o romance do Mestre apareça em um primeiro momento presentemente na realidade presente soviética, em seu mesmo plano, e os outros textos aludidos no decorrer do romance (como o poema de Biezdomni), não. A verdade da existência de Jesus está no romance do Mestre que, no primeiro momento, sai da boca de Woland e assalta a

\footnotetext{
65 “Desacoplada da adivinhação moralista, senão até mesmo das vozes educadoras, a linguagem não é mais tradução de significados pré-linguísticos, mas uma mídia entre mídias.” (Tradução nossa).

66 “Unterm Anschein historischer Regression treibt Nietzsche Schriftstrukturen ins Extrem. Wenn Faust LogosÜbersetzung in der Geschichte des Zeichens den Augenblick ohne Paradigmabewusstsein markiert hat, so ist Nietzsches Schreiben, in Programm und Praxis, die Errichtung der reinen Differentialität“ (KITTLER, 2003, p. 229) "Sob a aparência de regressão histórica, Nietzsche forçou as estruturas de escrita ao máximo. Se a tradução de Logos do Fausto marcou o momento sem consciência de paradigma na história dos signos, a escrita de Nietzsche, em teoria e práxis, é a instauração da pura diferencialidade.” (Tradução nossa). Voltaremos adiante ao assunto da tradução do Logos bíblico por Fausto.
} 
realidade "presente" soviética: ela vale como a verdade, como nexo responsável entre narrativa e realidade do método paródico enquanto um experimento de transposição de mídias. Esse Jesus do romance do Mestre não é uma tradução da Bíblia para o russo, nem uma ruminação hermenêutica dos evangelhos, mas uma investigação sobre a noção de verdade na representação, na medida em que é também uma sátira menipeia. O romance parodia (no sentido de paródia explorado no segundo capítulo) não apenas outros textos, como os evangelhos, mas também os próprios critérios de verossimilhança de seus métodos de representação do real.

$* *$

Os comentadores de Bulgákov, como Weir, defendem a necessidade de se determinar "a estrutura básica de intertextualidade" do romance de Pilatos, mas o fazem sem pensar nas consequências disso do ponto de vista da verdade da representação literária ${ }^{67}$. Podemos ver isso em jogo aqui a partir de Boris Groys, que percebeu algo que - até onde eu sei - nenhum outro autor que se debruçou sobre $O$ Mestre e Margarida foi capaz de indicar, a saber, a presença de Nietzsche na estrutura intertextual do romance dentro do romance:

Os motivos nietzschianos aparecem de forma ainda mais clara nos capítulos que ocorrem em Jerusalém, e que descrevem Jesus como indivíduo. A construção estética dessas cenas baseia-se em dois modelos literários do Jesus histórico. Trata-se, por um lado, do romance de Ernst Renan, A vida de Cristo, e, por outro lado, de $O$ Anticristo, de Nietzsche, uma caracterização de Jesus de Nazaré que pode ser lida como antítese às descrições do Cristo de Renan. (GROYS, 2013, p. 170).

\footnotetext{
67 "Because literary tradition is, in an important sense, the relationships among literary texts, establishing the basic structure of intertextuality in The Master and Margarita is crucial. At the center of the novel is the interpolated text of the Master's story of Pontius Pilate and Yeshua. Although it makes a claim on the truth (i.e., that it is not "textual" at all) by retelling the Passion, the Pilate story is perhaps the most intertextual segment of the novel. Outside the context of the rest of the novel, it is connected with all other versions of the Christ-Pilate story, the Gospels, the Apocrypha, lives of Christ (such as Renan's), Marxist-Leninist debunkings of religion, and so forth. In addition, in style and in its attempted representation of divine goodness, the Pilate story is related to a number of nineteenth-century novels, especially Dostoievsky's The Idiot and The Brothers Karamazov" (WEIR, 2002, p. 8). "Porque a tradição literária é, em um sentido importante, as relações entre textos literários, estabelecer a estrutura básica de intertextualidade no O Mestre e Margarida é crucial. No centro do romance está o texto interpolado da estória do Mestre sobre Pôncio Pilatos e Jeshua. Embora clame pela verdade (i.e. clame não ser "textual") ao recontar a Paixão, a estória de Pilatos talvez seja o segmento mais intertextual do romance. Afora o contexto do resto do romance, ele tem conexão com todas as outras versões da estória de Cristo-Pilatos, os evangelhos, os apócrifos, vidas de Cristo (como a de Renan), desmoralizações marxistas-leninistas da religião, entre tantos. Ademais, em seu estilo e tentativa de representação da bondade divina, a estória de Pilatos está relacionada a alguns romances do século XIX, especialmente O idiota e Os irmãos Karamázov de Dostoiévski." (Tradução nossa).
} 
Escrever ficcionalmente sobre o Jesus histórico vai ao encontro da crítica de Nietzsche ao Jesus histórico romantizado de Renan. Renan fez de Jesus um homem - um tipo - de seu tempo ao utilizar conceitos, tipos e parâmetros do romantismo para representá-lo historicamente, tal como Biezdomni o fez. Nietzsche, ao expor os pressupostos metafísicos de seu tempo, se considera capaz de apontar ao mesmo tempo mais rigorosamente o Jesus histórico e um Jesus do futuro do seu tempo ${ }^{68}$.

Ao promover uma crítica, com ajuda de Dostoiévski, à idealização e elevação de um homem - operadas por Renan -, as considerações de Nietzsche transpostas a $O$ Mestre $e$ Margarida confundem a recepção literária cristã com a da literatura russa. Isso é tematizado no romance e em Nietzsche de modo muito parecido desde a recepção polifônica dos primeiros cristãos em relação às falas e atitudes de Jeshua-Jesus. No romance, ele diz:

- Não, não, Hegemon - dizia o prisioneiro, retesando-se todo no desejo de convencer - anda por aí um sujeito com um pergaminho de pele de bode, que escreve sem parar. Certa vez, dei uma espiada nesse pergaminho e fiquei horrorizado. Decididamente, eu não disse nada daquilo que estava anotado lá. (BULGÁKOV, 1992, p. 29).

Esse sujeito é Mateus Levi, coletor de impostos que no começo insultava Jeshua chamando-o de cão, insulto extremamente importante porque aproxima a representação de Cristo no romance dentro do romance em $O$ Mestre e Margarida do ideário cínico e parresiástico. Em Nietzsche também vemos esse movimento que, embora inspirado em Dostoiévski, está constituído em uma Stimmung bastante diversa da cristã ortodoxa deste: "no fundo, houve apenas um cristão, e ele morreu na cruz. O 'evangelho' morreu na cruz. O que desde então se chamou 'evangelho' já era o oposto daquilo que ele viveu: uma 'má nova', um disangelho" (NIETZSCHE, 2007, p. 45). A seção 45 de O Anticristo é constituída só de

\footnotetext{
68 "O que me importa é o tipo psicológico do Redentor. Afinal, ele pode estar contido nos evangelhos apesar dos evangelhos, ainda que mutilado ou carregado de traços alheios: como o de Francisco de Assis está conservado em suas lendas, apesar de suas lendas. Não a verdade quanto ao que fez, o que disse, como realmente morreu; mas a questão de o seu tipo ser concebível, de haver sido 'transmitido'. As tentativas que conheço de extrair dos evangelhos até a história de uma 'alma' me parecem provas de uma execrável leviandade psicológica. O senhor Renan, esse bufão in psychologicis [em coisas psicológicas], utilizou em sua explicação do tipo Jesus os dois conceitos mais inadequados que pode haver nesse caso: o de gênio e o de heróis ('héros'). Se existe algo não evangélico, é o conceito de herói. [...] Que significa 'boa nova'? A vida verdadeira, a vida eterna foi encontrada não é prometida, está aqui, está em vocês: como vida no amor, no amor sem subtração nem exclusão, sem distância. Cada um é filho de Deus - Jesus não reivindica nada apenas para si -, como filho de Deus cada um é igual ao outro... Fazer de Jesus um herói! - E que mal-entendido é sobretudo a palavra 'gênio'! Nada de nosso conceito de 'gênio', um conceito de nossa cultura, tem algum sentido no mundo em que vive Jesus. Falando com o rigor do fisiólogo, caberia uma outra palavra aqui - a palavra 'idiota'” (NIETZSCHE, 2007, p. 36).
} 
"algumas amostras do que essa gente pequena pôs na cabeça, do que puseram na boca de seu mestre" (NIETZSCHE, 2007, p. 45).

Além dessas semelhanças iniciais, podemos encontrar motivos para a possível presença de Nietzsche em $O$ Mestre e Margarida do ponto de vista do próprio método paródico de Bulgákov, na medida em que estudos do final da década de 1980 e início da década de 1990 apontaram que algumas das ideias mais gerais de Nietzsche atuavam sub-repticiamente no ideário soviético oficial e em diversas outras produções culturais russas pré- e pósrevolucionárias ${ }^{69}$. Para Bulgákov, a possível aproximação com uma de suas obras pode ter ocorrido como uma busca por assumir uma postura crítica em relação às várias tradições culturais russas, na medida em que Nietzsche pode ter constituído um terreno comum para a polifonia de discursos sobre Jesus Cristo do período soviético, mesmo que, ao mesmo tempo, essa presença de Nietzsche nas doutrinas e posições (marxistas, cristãs ortodoxas etc.) desvirtuasse a rigidez sistemática e conceitual delas. Vale ressaltar que foi, entre outros motivos, essa mesma característica de aproximar discursos muitas vezes aparentemente tão distantes que levou ao estudo da presença de Nietzsche no ideário russo-soviético no fim do século XIX e nas três primeiras décadas do século XX:

Nietzsche's influence in Russia was profound, widespread, and enduring. A philosopher for rebels, his impact proved greatest during what in retrospect can be seen as a transition period in Russian history [...]. After 1912, Nietzsche's influence becomes more difficult to trace. ${ }^{70}$ (ROSENTHAL, 1986, p. 3).

Ou ainda, já especificamente sobre a presença de Nietzsche no período soviético:

It was not so much the direct influence of Nietzsche's ideas, though that was certainly found, that accounts for his continued presence in the culture, but the persistence, in transmuted form, of ideas and images that had become embedded in the culture before the Bolshevik Revolution. ${ }^{71}$ (ROSENTHAL, 1994, p. 2).

\footnotetext{
${ }^{69}$ Ver (ROSENTHAL, 1986) e (ROSENTHAL, 1994).

70 “A influência de Nietzsche na Rússia foi profunda, ampla e duradoura. Um filósofo para rebeldes, seu impacto provou-se o maior de todos durante o que, em retrospecto, pode ser visto como um período transitório na história russa [...]. Depois de 1912, a influência de Nietzsche se torna mais difícil de ser traçada.” (Tradução nossa).

71 “Não é tanto a influência direta das ideias de Nietzsche, embora isso fosse certamente encontrado, que explica sua presença continuada na cultura, mas sim a persistência, em forma transmutada, de ideias e imagens que se encravaram na cultura antes da Revolução Bolchevique." (Tradução nossa).
} 
O longo período em que as obras de Nietzsche estiveram censuradas na URSS, desde o início da década de 1920 até a Queda do Muro de Berlim (1989), fez com que a compreensão da real dimensão do impacto de Nietzsche na cultura pré soviética e soviética assumisse um enorme significado na Rússia. É na década de 1990 que as obras completas de Nietzsche passam a ser organizadas em russo e tentativas acadêmicas de leituras filosóficas institucionalizadas em universidades passam a ser feitas. É claro que, nesse momento, a avidez da vida acadêmica filosófica não era só por Nietzsche, mas também por outros autores como Heidegger; mas a ressignificação histórica do ambiente que moldou a ideologia oficial do período stalinista passava pela devida compreensão da obra do autor do século XIX.

Mas por que Nietzsche, de repente, tornara-se tão importante para essa reinterpretação? Nossa hipótese é a de que, ao contrário de outros autores igualmente impactantes e vulgarizados da época, como Marx e Freud, Nietzsche talvez seja aquele que una toda uma cultura que até então havia sido interpretada e articulada a partir de sistemas conceituais que a priori marcavam diferenças fundamentais entre os autores e agentes sociais. Se é muito fácil saber quem segue ou não o método dialético marxista, no caso de Nietzsche, apesar da clara aversão de Lênin e de sua mulher a ele e de toda a história de alteração dos manuscritos perpetrada pela irmã antissemita do alemão, podemos dizer que essas identidades aparentemente contrastadas se tornam mais cinzentas. Nietzsche é útil porque deixa esse período novamente modelável para quem quiser interpretá-lo ao se debruçar sobre ele.

Desse modo, talvez até mais do que em relação a outros contextos culturais da mesma época, a discussão sobre a recepção de Nietzsche na Rússia e na URSS se reavivou nas duas últimas décadas do século XX.

Simplesmente sugerir essa relação de $O$ Mestre e Margarida com Nietzsche já nos abre uma série de questões: essa relação ocorre por que Bulgákov está pensando em seu próprio tempo, vendo em Nietzsche um autor para pensá-lo de modo mais apropriado? Essa relação ocorre por que Bulgákov vê a ligação entre o mundo literário pré e pós-revolucionário através de Nietzsche?

Mesmo que a resposta para essas e outras questões seja negativa, ver $O$ Mestre $e$ Margarida pelo prisma de Nietzsche nos permite pensar que o romance não busca uma volta ao passado da literatura russa, mas a outro futuro possível inscrito nessa tradição. Outro futuro que não era nem o do passado (que voltou com força - tendo justamente este romance como baluarte - na decadência e no fim da URSS), nem o de seu presente, ao menos o oficial: se 
pudermos entrever essa possibilidade a partir dessa aproximação, aí estará o que há de mais valioso no romance.

Mas Bulgákov o leu de fato ou simplesmente "picked up ideas which were "in the air"” 72 (ROSENTHAL, 1994, p. 8)? Não tem a menor importância, pois perceber essa ligação nos dá ânimo para pensar que Bulgákov de fato tinha um escopo mais amplo do que simplesmente escrever libelos antirrevolucionários, que meramente criticassem a URSS; ele poderia estar de fato interessado em pôr em jogo uma ideia de humano, obviamente diferente daquela soviética oficial, mas não por isso oposta ou que tomasse esta simplesmente por base do que não era esse seu humano:

O problema que aqui coloco não é o que sucederá a humanidade na sequência dos seres (- o homem [Mensch] é um final -); mas sim que tipo de homem [Mensch] deve-se cultivar, deve-se querer, como de mais alto valor, mais digno de vida, mais certo de futuro. (NIETZSCHE, 2007, p. 11).

Assim, a ideia compartilhada pela ideologia oficial soviética de um melhoramento do humano, o progresso, Nietzsche (2007, p.11) o chama de "ideia moderna, ou seja, uma ideia errada": para ele, não se pode falar em um desenvolvimento contínuo para o melhoramento da humanidade, já que outras épocas e outros povos já apresentaram humanos mais desenvolvidos do que os de "hoje". O cristianismo é uma mentalidade que "travou uma guerra de morte" contra os casos de êxito do humano, os quais foram capazes de elevar o sentimento de vida e o poder: é a religião da compaixão que entrava a lei da evolução, "[conservando] o que está maduro para o desaparecimento, [pelejando] a favor dos deserdados e condenados da vida, pela abundância dos malogrados de toda espécie que mantém vivos, [dando] à vida mesma um aspecto sombrio e questionável” (NIETZSCHE, 2007, p. 13). E esse cristianismo é expresso no que Nietzsche chama de "instinto de teólogo", uma noção vasta o suficiente para incluir desde os autores dos evangelhos até Kant como moralista "- e era contemporâneo de Goethe” (NIETZSCHE, 2007, p. 17) -: são aqueles que buscam definir a verdade a partir da moralidade ou de um critério extra-humano - Deus, justamente -, e não pelas relações de poder entre humanos.

Jesus mesmo só possui tal instinto de teólogo de modo ambíguo. Pois, por um lado, chama todos - até mesmo seu carrasco estatal, o Hegemon, Pilatos, "a única figura digna de respeito em todo o Novo Testamento" (NIETZSCHE, 2007, p. 56) ${ }^{73}$ - de "bom homem"

\footnotetext{
72 “[...] pegou ideias que 'estavam no ar'.” (Tradução nossa).

${ }^{73}$ Agamben cita essa passagem sem dizer o porquê dessa afirmação de Nietzsche (2007, p. 56): "Levar a sério uma questão entre judeus - ele não se persuade a fazer isso. Um judeu a mais ou a menos - que importa?... O
} 
[humano] (BULGÁKOV, 1992), ou seja, rejeita toda a realidade entendida como a relação de poder entre os homens, o alto e o baixo, a instituição Igreja, o Estado e suas leis:

ódio instintivo a toda realidade, como refúgio no "inapreensível", no "incompreensível", como aversão a toda fórmula, todo conceito de tempo e lugar, ao que é sólido, costume, instituição, Igreja, como estar em casa num mundo que já não é tocado por espécie nenhuma de realidade, um mundo apenas "interior", "verdadeiro", "eterno"... "O reino de Deus está em vós"... (NIETZSCHE, 2007, p. 36).

Por outro lado, essa mesma recusa da realidade não levava a uma doutrina, a um dizer sobre o bem e o mal, mas a uma prática constituída a partir dessa equiparação de todos como filhos de Deus. Era essa atuação ética, para Nietzsche, a boa nova que Jesus trouxe. Uma nova prática, "uma nova conduta, não uma nova fé..." (NIETZSCHE, 2007, p. 41):

Esse "portador da boa nova" morreu como viveu, como ensinou - não para "redimir os homens", mas para mostrar como se deve viver. A prática foi o que ele deixou para a humanidade: seu comportamento ante os juízes, ante os esbirros, ante os acusadores e todo tipo de calúnia e escárnio - seu comportamento na cruz. (NIETZSCHE, 2007, p. 42).

Se "Somente nós, espíritos tornados livres, temos o pressuposto para entender algo que dezenove séculos entenderam errado" (NIETZSCHE, 2007, p. 42), o Cristo de Bulgákov adota precisamente esse comportamento perante seu juiz, o que Groys percebe: "O Cristo de Bulgákov não fala através de parábolas, também não dá conselhos inteligentes, mas aparece como um sábio médico ou psicólogo (como coach)" (GROYS, 2013, p. 172 tradução com algumas modificações). Em resposta à pergunta que Nietzsche (NIETZSCHE, 2007, p. 56) chama de a tirada mais sutil (Urbanität) de todos os tempos - o que é a verdade? (AGAMBEN, 2014, p. 38), porque aniquila a própria noção de verdade como valor, Jeshua diz, na passagem (do romance) já citada, que a verdade é que Pilatos está com dor de cabeça: com essa resposta, Jeshua inverte o papel de carrasco e de juiz, de nobre e de decadente, ensina não a redenção, mas uma prática curativa que põe a nu o desejo melancólico de morte como covardia, e aqui vale a pena citar novamente a seguinte passagem, e um pouco mais além:

nobre escárnio de um romano, ante o qual se comete um impudente abuso da palavra 'verdade', enriqueceu o Novo Testamento com a única frase que tem valor - que é sua crítica, até mesmo sua aniquilação". (AGAMBEN, 2014, p. 23). 
- A verdade consiste primeiramente em que o senhor está com dor de cabeça, e essa dor é tão forte que o senhor pensa covardemente em morrer. O senhor não pode sequer pensar em alguma coisa e deseja apenas que venha o seu cão, que parece ser a única criatura por quem nutre algum afeto. Mas os seus tormentos vão acabar agora mesmo, a dor de cabeça passará.

O secretário arregalou os olhos para o prisioneiro e parou no meio de uma palavra. [...]

Então o procurador [Pilatos] levantou-se da poltrona, apertou a cabeça com as mãos e no seu rosto amarelado, bem barbeado expressou-se o espanto. Mas ele reprimiu-o imediatamente com a sua força de vontade, e recostou-se novamente na poltrona. [...]

- Pois bem, tudo já terminou - dizia o prisioneiro olhando com benevolência para Pilatos - e eu me alegro imensamente com isso. Eu aconselharia, Hegemon, que deixasse por algum tempo o palácio e desse uma volta, a pé, nos arredores [...]

O secretário empalideceu mortalmente e deixou cair o rolo no chão.

- A sua desgraça é que o senhor é demasiadamente fechado e perdeu definitivamente a fé nos homens - prosseguia o prisioneiro amarrado que ninguém tinha interrompido - Concorde, não se pode dedicar todo o afeto apenas a um cão. A sua vida é pobre, Hegemon - e o homem tomou a liberdade de sorrir. (BULGÁKOV, 1992, p. 31).

A narrativa prossegue com o narrador se aproximando da subjetividade do funcionáriosecretário que registrava a conversa (em um outro texto...) e que não acreditava no que via e ouvia. A próxima fala de Pilatos é baixinha e em grego: “- Confesse - perguntou baixinho Pilatos, em grego - você é um grande médico?” (BULGÁKOV, 1992, p. 32).

Nessa aproximação de Jeshua com o ofício do médico pelas palavras vemos se conjugar a versão da lenda de Pilatos de narrativas extrabíblicas, como Fílon de Alexandria, e a versão russa - que agrada a Nietzsche - de Jesus como psicólogo, isto é, como "um médico que cura todas as doenças somente com sua palavra" (AGAMBEN, 2014, p. 29).

Para melhor entender porque estamos insistindo nessa relação com Nietzsche, vale aqui perguntar: como seria uma interpretação deste trecho pelo prisma de Dostoiévski? Ela talvez começasse enfatizando o modo de o narrador nomear Jeshua e o sorriso dele para Pilatos, não fazendo distinção de sua posição social: "o homem tomou a liberdade de sorrir".

Míchkin é Jesus, no sentido de que "vive na tensão escatológica que era (e é) a alma da ética cristã primitiva, cuja doutrina do ágape totalmente egoísta foi concebida na mesma perspectiva do final iminente dos tempos" (FRANK, 2013b, p. 425). Míchkin é um Jesus, mas será que Jeshua Ha-Nozri é um Míchkin? Por que relacionar o romance com Nietzsche e não apenas com Dostoiévski?

Porque, com Nietzsche, podemos apontar o horizonte da presença da herança literária de Dostoiévski e dos autores da assim chamada revolução espiritual cristã ortodoxa, sem para isso ter de ver Bulgákov também pensando a partir de categorias eslavófilas ou cristãs 
ortodoxas. Para dizer com todas as letras: sem Nietzsche, o problema de Bulgákov no romance seria simplesmente teológico, uma questão sobre qual a fé mais verdadeira em Cristo, ou ainda sobre a interpretação ortodoxa ao modo russo da paixão de Cristo; com o autor alemão, o problema assume uma nova cara, mais filosófica, mais (teórico)literária: a questão do homem e da verdade da (auto)representação.

Vejam em Frank um exemplo para ilustrar o que estou tentando dizer:

O que essas estórias querem mostrar é a fé religiosa e a consciência moral que constituem um atributo inerradicável do povo russo, independente da razão, ou mesmo de algum tipo de moral social convencional. "A essência do sentimento religioso", Mychkin explica, "não pode de modo algum ser apreendida por algum tipo de raciocínio ou de ateísmo, e nada tem a ver com crimes e más ações, quaisquer que eles sejam. [...] Mas o principal é que notarás mais clara e rapidamente no coração russo do que em qualquer outro". (FRANK, 2013b, p. 434, grifo nosso).

Pensemos, por exemplo, na famosa polêmica entre Dostoiévski e Tchernichévski, a qual se situa uma década antes da entrada de Nietzsche na Rússia. Nela, há uma discussão em torno da racionalidade: enquanto o revolucionário Tchernichévski, sendo influenciado por ideais ocidentais, preocupava-se com as possibilidades reais do egoísmo racional ser a base de uma nova moral que levaria a mudanças sociais determinantes, Dostoiévski parece querer indicar a finitude e pequenez da razão para lidar com assuntos humanos. Talvez pudéssemos perceber até que ponto o dito irracionalismo não pode nos servir para pensar uma crítica à razão que não a rejeita, mas a alarga (talvez até mesmo contra Dostoiévski, uma espécie não de $i$-, mas de contrarracionalismo).

Aqui, vemos que a crítica à razão em linhas gerais pode ser esboçada como estando conectada com uma crítica à cultura ocidental, assim como à defesa da religião, enquanto a defesa da razão vem acompanhada de um ceticismo, até mesmo de um niilismo, uma abertura ao mundo ocidental e uma crítica às tradições eslavófilas - os nobres, o tzar, a igreja.

O poder e a força de Nietzsche ao entrar nesse debate é o de embaralhar os lugares do discurso, as associações óbvias entre os valores de um eslavófilo e de um ocidentalista, tal como se constituíra nas décadas de 1860 e 1870 na Rússia. Com isso, a interpretação que ressalta a relação da intelligentsia com Nietzsche aos poucos esfumaça essa chave conceitual que em geral temos como presente no inteiro decorrer da história moderna russa até a Revolução, e obriga-nos novamente a considerar as diversas vozes do debate sem modelos predefinidos: sua ajuda inestimável reside em que, com ele, abre-se a possibilidade de uma crítica à razão que não signifique uma defesa dos valores eslafóvilos e cristãos ortodoxos, abre-se a possibilidade 
até mesmo de uma reinterpretação de Dostoiévski e também - por que não? - de Tchernichévski.

É claro, no entanto, que há muito mais coisas entre o céu e a terra, i.e., entre Dostoiévski, Nietzsche e Bulgákov, do que podemos tematizar aqui. O simbolismo russo, por exemplo, pode ser entendido como um movimento teológico, filosófico, artístico, literário e cultural profundamente influenciado por Soloviov (e, por consequência, por Dostoiévski), que desenvolve os problemas e questões dessa tradição mas que também já se relacionam com a presença cada vez maior de Nietzsche no ambiente cultural russo. A influência de Nietzsche sobre autores os mais variados, como Górki, Lunachárski, Bieli, Rudolf Steiner, Blok e Bakhtin, pode ser tida como uma evidência desse embaralhamento que Nietzsche promove na cultura russa da virada do século XIX para o XX. Nesse contexto, fica mais fácil entender a especificidade desse movimento em relação aos outros simbolismos (o francês, que o procedeu, por exemplo), a saber, a de não fazer uma apologia da arte pela arte, já que viam a arte como uma teurgia em busca de uma nova fé, um novo homem:

For the symbolists and their confreres, a revolution of the spirit entailed a new set of values centering in creativity and personal freedom. Challenging the materialism and positivism of the atheistic intelligentsia and the asceticism and humility preached by the Russian Orthodox Church, and detesting the bourgeois society of the West, the symbolists had a vision of a new man, idealistic, sensitive, emotionally free, a progenitor of a new culture characterized by freedom, beauty, and love. Russian symbolism was never an art-for-art's-sake movement. Unlike their French precursors, Russian symbolists (except for Briusov) regarded art as a theurgy, a path of higher truths, even to a new faith. ${ }^{74}$ (ROSENTHAL, 1990, p. 25).

Seria de se lamentar que os simbolistas, como Dostoiévski, também não "tenha[m] vivido na proximidade desse interessantíssimo décadent [Messias, o profeta, João Batista...] quero dizer, alguém que pudesse perceber o arrebatador encanto dessa mistura de sublime,

\footnotetext{
74 "Para os simbolistas e seus confrades, uma revolução do espírito compreendia um novo conjunto de valores centrados na criatividade e liberdade pessoal. Desafiando o materialismo e positivismo da intelligentsia ateísta e o ascetismo e a pregação de humildade da igreja ortodoxa russa, bem como detestando a sociedade burguesa do ocidente, os simbolistas tinham uma visão de um novo homem, idealista, sensível, livre emocionalmente, um progenitor de uma nova cultura caracterizada pela liberdade, beleza e amor. O simbolismo russo nunca foi um movimento de arte pela arte. Ao contrário de seus precursores franceses, os simbolistas russos (exceto Briúsov) viam a arte como uma teurgia, um caminho de verdades mais elevadas que levava a uma nova fé." (Tradução nossa).
} 
enfermo e infantil" (NIETZSCHE, 2007, p. 38), como diz Nietzsche; ou seriam eles mesmos uma busca pelo retorno (que pode ser mais ou menos "múltiplo e contraditório" 75 ) da Stimmung dos primeiros cristãos (como em geral o cristão místico o é independente de seu tipo de cristianismo, sendo Angelus Silesius um bom exemplo disso)?

Gostaria de proceder à citação de alguns exemplos que podem nos dar uma pequena dimensão do que se falava sobre Jesus, César e os romanos, entre outras coisas, na Rússia mais ou menos na época de Bulgákov. Espero que com essa exposição seja possível avançar na argumentação sobre a importância da presença de Nietzsche para a interpretação de $O$ Mestre e Margarida. Nossa sugestão é a de que Bulgákov estava dialogando com essa tradição, mas deve ser situado bem distante dela. Ele teria colocado em diálogo polifônico e crítico as diversas posições de seu tempo. Com seu método paródico de transposição de mídias e discursos, fez com que Jeshua tenha sido representado não como um símbolo, mas em sua historicidade, como um humano.

Em um texto de 1906 chamado Anarquismo místico, logo após a Revolução malograda de 1905, que gerou uma guinada mística nos anos seguintes - vale lembrar que o próprio Bulgákov se autodenomina místico em carta ao alto comissariado stalinista -, Georgi Chulkov (1879-1939) escreve as seguintes palavras sobre Jesus que ressoam no Jeshua de Bulgákov:

\begin{abstract}
Authority and freedom! Caesar and the Galilean! How do we reconcile the irreconcilable? This Jesus Christ is the greatest rebel who ever lived on Earth. What is Brutus, what is Cassius, in comparison with Him? They killed only Julius Caesar, whereas $\mathrm{He}$ is killing the Caesars and Augustuses. Is reconciliation between the Galilean and Ceaser conceivable? Is there enough room on Earth for them both? After all, He lives on Earth. [...] The Galilean lives, I say; so the Jews and Romans were wrong in imagining that they had killed Him. He lives in man's rebellious spirit, lives in his persistent resistance to and contempt for all invisible authority. "Render unto Caesar the things that are Caesar's, and unto God the things that are God's". Man's lips have yet to utter ever anything more insidious. What is hidden behind these words? Precisely what and how much ought to be rendered unto Caesar? These words are like the club that knocks the crown off Caesar's head. ${ }^{76}$ (CHULKOV, 1990, p. 185).
\end{abstract}

\footnotetext{
${ }^{75}$ Nietzsche usa a expressão na frase seguinte à acima citada: "Como tipo da décadence, o tipo poderia, de fato, ser peculiarmente múltiplo e contraditório: não é de se descartar inteiramente esta possibilidade”.

76 “Autoridade e liberdade! Cesar e os galileus! Como reconciliar o irreconciliável? Esse Jesus Cristo é o maior rebelde que jamais viveu na Terra. O que é Brutus, o que é Cássio, em comparação com Ele? Eles mataram apenas Júlio Cesar, enquanto Ele está matando os Césares e Augustos. É concebível a reconciliação entre os galileus e Cesar? Há espaço na Terra para ambos? Afinal, Ele vive na Terra. [...] O galileu vive, eu digo; então os judeus e romanos estavam errados ao imaginar que $\mathrm{O}$ mataram. Ele vive no espírito rebelde do homem, vive no seu desprezo por qualquer autoridade invisível e na sua resistência persistente contra elas. 'Dê a Cesar o que é de Cesar e a Deus o que é de Deus'. Os lábios humanos ainda estão para conhecer algo ainda mais insidioso. O que está oculto atrás
} 
Nessa passagem talvez fique mais claro o que poderia querer dizer o misticismo de Bulgákov e como ele se relaciona com seu último romance: talvez possa estar próximo do anarquismo e significar ser contra instituições que ditam respostas prontas para a pergunta do sentido da existência, como a Igreja ou o stalinismo. Já nesse texto de Merejkovski de 1907, Revolução e religião, mais uma vez aparecem Jesus e César para se pensar o presente russo da Revolução que não deu certo, e o papel da religião na Revolução como abrangendo o típico russo e o anarquismo anti-institucional:

Thus the religious consciousness of the Russian Revolution can explain the unconscious prophetic horror of the Russian schism, that the tsar is the Antichrist. Although naturally the Eastern Caesar is as much of an Antichrist as the Western archpriest, they are both just two historical symbols, two paths to what is beyond history, to the last incarnation of the Beast. In the "Orthodox Catechism" the Decembrists criticize the deepest mystical basis not only of the autocracy, but of any state power in general. "There will be one tsar for all in heaven and on Earth - Jesus Christ" - this aspiration of Russian seekers of the City to come was unrealizable either by a constitutional monarchy, or by a bourgeois republic - about which the people of that time dreamed - or even by a social-democratic republic, about which the contemporary revolutionaries dream. It can be achieved only by absolute statelessness, by the absence of authority as an affirmation of divine authority. (MEREZHKOVSKY, 1990, p. 200) ${ }^{77}$.

Essas são apenas algumas citações - dentre tantas - que nos indicam como episódios relacionados a Jesus, noções como Cristo e Anticristo - muitas vezes com cunho apocalíptico, como a narrativa do último texto de Soloviov escrito em 1900, Uma história do Anticristo - e à história romana eram constantemente trazidos à tona para pensar o presente ao longo do começo do século XX russo entre autores mais ou menos independentes, que tinham em comum talvez unicamente aquilo a que se opunham: a Igreja Ortodoxa russa como instituição, o ateísmo, o tzarismo e o materialismo.

\footnotetext{
dessas palavras? Precisamente quanto e como deve ser dado a Cesar? Essas palavras são como o golpe que abate a coroa da cabeça de Cesar.” (Tradução nossa).

77 “Assim, a consciência religiosa da Revolução Russa pode explicar o horror profético inconsciente do cisma russo de que o tsar seja o anticristo. Embora o Cesar oriental naturalmente seja tão um anticristo como o arcebispo ocidental, ambos são apenas dois símbolos históricos, dois caminhos para o que está além da história, para a última encarnação do demônio. No 'catecismo ortodoxo' os dezembristas criticam a profunda base mística não apenas da autocracia, mas de qualquer poder estatal em geral. 'Haverá um tsar para todos no céu e na Terra - Jesus Cristo' - essa aspiração dos russos que procuram a Cidade por vir era impossível de ser realizada tanto por uma monarquia constitucional, como pela república burguesa - com a qual as pessoas da época sonhavam -, e até mesmo por uma república social-democrática, com a qual os revolucionários contemporâneos sonham. Isso só pode ser atingido por uma ausência absoluta do Estado, pela ausência de autoridade como uma afirmação da autoridade divina." (Tradução nossa).
} 
Na negação dessas instâncias, acabavam defendendo o lema da Revolução Francesa igualdade, liberdade, fraternidade - no que eles diziam ser um sentido mais amplo. É o caso do transumanismo russo de figuras como Nikolai Fedorovitch Fedorov e Alexander Aleksandrovich Bogdanov. Bogdanov era bolchevique e conhecido pelos experimentos em transfusão de sangue em busca de um método de imortalidade que fazia em si mesmo - e pelo que morreu, em $1924^{78}$. Essa busca tinha como inspiração as ideias do primeiro, Fedorov, que defendia uma igualdade para além da material, no sentido de uma igualdade entre todos aqueles que contribuíram, no passado e no presente, para o estabelecimento do comunismo. Seria injusto que apenas os humanos futuros o gozassem, então era preciso desenvolver a ciência em busca de uma partilha não só material, mas também temporal da vida de cada ser humano (obviamente, para isso seria preciso também que a ciência fosse capaz de ressuscitar...): o Estado funcionaria como uma espécie de museu, organizando quais obras estariam expostas e quais repousariam aguardando sua vez, ou seja, quais humanos estariam vivos, por quanto tempo etc., e quais estariam mortos. É claro, o pressuposto é que não caberiam na Terra todos os humanos: o comunismo como uma sociedade de mortos-vivos, literalmente.

Nesse sentido, vale ressaltar que na representação humana de Jesus na narrativa do Mestre, não há a ressureição, mas o enterro do corpo de Jeshua com marcas feitas com anéis para identificá-lo. Levi, após saber que foi Pilatos quem matou Judas, pede um pedaço limpo de pergaminho, com o que a escrita e a inscrição parecem ser mais importantes aqui do que questões teológicas propriamente ditas, as quais parecem ocorrer apenas como um tema capaz de pôr em diálogo uma tradição que pensa o seu tempo a partir de categorias e problemas teológicos.

No ensaio Catilina, de 1918, o poeta lírico Blok protagoniza um dos grandes momentos dessa aproximação ao chamar Catilina de "bolchevique romano" e traçar um paralelo entre o declínio de Roma e a conspiração de Catilina (escrita por Cícero), a ascensão do cristianismo, a Revolução Bolchevique, a representação de Catilina por Ibsen ("um grande escritor, inspirado pela revolução mundial de 1848" [BLOK, 1990, p. 315]) e o surgimento de uma nova fé ${ }^{79}$ :

\footnotetext{
${ }^{78}$ Ver: (Nachrichten aus der ideologischen Antike - Marx - Eisenstein - Das Kapital, 2008)

${ }^{79}$ Para uma análise mais detalhada de várias questões tratadas aqui de modo muito rápido, recomendo como porta de entrada o artigo de G. Nivat, Elementos milenaristas na Revolução Russa: "O poema de Blok, Os doze, foi uma das mais importantes expressões dessa crença em uma revolução espiritual simbolizada pela figura de Jesus Cristo andando pelas ruas da revolucionária São Petersburgo. Em seu famoso discurso, proferido na Academia Filosófica Livre (Volfila), Blok deu uma interpretação cósmica à revolução. Tal discurso é intitulado A desintegração do humanismo. A tese de Blok era que a Revolução não seria somente um evento histórico russo, mas um evento de significação universal, em que o humanismo europeu viria a ser condenado. Essa interpretação pessimista e lírica da Revolução Russa - semelhante às teses de Spengler em $O$ declínio do Ocidente (embora o livro de Spengler
} 
Thus, the Roman "bolshevik" Catiline perished. Roman citizens rejoiced; they decided "to a dog-a dog's death". Distinguished writers shared their compatriots' opinions in their compositions.

When Christ was born, Rome's heart stopped beating. But the organism of the monarchy was so enormous that it took centuries for all the parts of its body to stop its convulsive twitching. ${ }^{80}$ (BLOK, 1990, p. 314-5).

Este mesmo Blok é um dos autores que escreveu um poema "sobre" Jesus Cristo logo após a Revolução, assim como Ivan Biezdomni. Os doze, termina assim:

\author{
Atrás - o cão esfomeado. \\ À frente - pendão sangrento, \\ Às avalanches insensível, \\ Às balas duras invisível, \\ Em meio às ondas furiosas \\ Da neve, coroado de rosas \\ Brancas, irrompe imprevisto - \\ À frente - Jesus Cristo. (BLOK, 2001, p. 77)
}

Nem dois anos depois, Trótski, em Literatura e revolução, chama esse poema de "o canto do cisne da arte individualista", usando palavras que talvez usaria também para o último romance de Bulgákov: "Esse poema sem dúvida é o maior êxito de Blok. Representa no fundo um grito de desespero pelo passado agonizante: e um grito de desespero que se levanta na esperança pelo futuro" (TROTSKI, 2007, p. 103). Embora perceba essa nostalgia pelo passado, ele parece não entender a que vem esse Jesus Cristo e chama a religião de Blok de "obscura e débil, de modo algum imperiosa, como seus poemas" (TROTSKI, 2007, p. 104). De suas palavras, poderíamos pensar Blok como alguém encantado com seu desencanto, um ateu encantado com seu ateísmo. Trótski conclui sua análise de Os doze assim: "Blok certamente não é um dos nossos. Mas veio até nós. E, ao fazê-lo, quebrou-se. O resultado de sua tentativa é a obra mais significativa de nossa época” (TROTSKI, 2007, p. 106). Isso porque Blok canta não esta Revolução, russa, torpe - violenta, já que "o símbolo da torpeza é que Vanka mata Katka com o fuzil" (TROTSKI, 2007, p. 105) -, não a "Revolução Russa real, feia, de hoje”,

não tivesse sido publicado ainda) - não era cínica, como Merejkóvski e outros pensavam, mas uma expressão de desespero universal" (NIVAT, 1998).

80 “Assim, pereceu o 'bolchevique' romano Catilina. Os cidadãos romanos alegraram-se; eles decidiram que 'para um cão - uma morte de cão'. Distintos escritores compartilharam com a opinião de seus compatriotas em seus ensaios. Quando Cristo nasceu, o coração de Roma parou de bater. Mas o organismo da monarquia era tamanho que levou séculos para que todas as partes de seu corpo deixassem de contrair convulsivamente.” (Tradução nossa). 
mas “a outra Revolução, verdadeira e reluzente". Talvez Trótski fosse filho de sua época demais para pensar sobre seu próprio desprezo pelo "afeto pelo passado", como diz Natali:

[...] a nostalgia aos poucos se tornou um problema de outra natureza, com o afeto pelo passado sendo acusado de ser politicamente repreensível e empiricamente insustentável. As duas acusações dependem de uma maneira particular de entender o passado e a história: é só quando o movimento da história passa a ser visto como necessariamente emancipador, progressivo e racionalmente compreensível que o apego ao passado pode ser condenado como uma aberração política e um obstáculo irracional. (NATALI, 2006, p. $13)$.

Ao concluir sua análise sobre a política da nostalgia, podemos ver Natali apontando a dificuldade da concepção que Trótski compartilha de compreender o desespero de Blok e a própria dificuldade de Blok de se compreender: "se não houver desencantamento e ateísmo, então outro território conceitual emerge. Neste caso estaríamos diante de algo que não é nem nostalgia, nem melancolia, e esse vocabulário, junto à crítica política à nostalgia, então perderia seu chão" (NATALI, 2006, p. 73). Essa dificuldade de se compreender de Blok não poderia ser algo que encanta o próprio poeta - um encanto pela dificuldade de se compreender como encantado ou como desencantado, dificuldade que ocorre por ser ambos ao mesmo tempo? $\mathrm{E}$ poderia ser essa inquietação talvez aquilo que na verdade dá o que Trótski chamou de "êxito" deste seu poema?

Muitos comentadores de Bulgákov afirmam como se fosse evidente que o personagem Mestre reflete Bulgákov, que ele é um alterego de Bulgákov, ou, mais cuidadosos, apontam algumas diferenças entre ambos. Como temos argumentado, cada elemento de $O$ Mestre $e$ Margarida não tem como "origem" apenas uma outra referência exterior ao romance, mas várias outras que, combinadas, dialogam e tornam uns aos outros ambivalentes. Não seria possível ver o Mestre como também sendo Blok ou outro dos simbolistas, anarquistas, místicos? Nesse sentido, a narrativa de Pilatos escrita pelo Mestre poderia ser a representação no romance do poema de Blok, ou dos textos acima citados. Não o modo como Bulgákov interpretaria o cristianismo, mas sim o modo como ele interpreta autores como esses de sua época.

Embora esteja retratando Jesus Cristo de uma maneira próxima a desses autores do assim chamado renascimento religioso russo, ele o faz utilizando um método de representação próximo ao naturalista, no qual acontecimentos do mundo natural acompanham o estado de espírito dos personagens e o narrador é capaz de adentrar e explicar seus pensamentos e desejos, principalmente os de Pôncio Pilatos. Mas mesmo esse método que poderíamos chamar de naturalista é parodiado, e muitas vezes sugere-se uma relação de causa e efeito invertida da 
naturalista: é o mundo natural, o sol, a lua, a tempestade, as trevas e o abismo que causam e governam os estados interiores e subjetivos dos personagens, tal como sugere Woland na parte soviética do romance. Isso nunca é de fato afirmado, mas apenas sugerido.

Talvez o ápice disso ocorra na passagem em que Mateus Levi acompanha de longe a execução de Jeshua pelos centuriões e trava um diálogo solitário com um deus ausente. Nessa passagem, em momento algum se abandona a convenção de verossimilhança do método de representação naturalista. Contudo, uma mudança brusca na natureza - que ultrapassa a narrativa do evangelho, embora utilize um de seus motivos apocalípticos, a tempestade - ocorre após Mateus praguejar contra o Deus bom e, em seu desespero, fazer um apelo às trevas. Uma paródia do ateu que ora a deus no momento de desespero? De qualquer modo, embora em nenhum momento se rompa uma noção de verdade naturalista convencional, não mística nem religiosa, num segundo plano de realidade - o da subjetividade e da crença do personagem em questão -, é verossímil que possam ter agido as forças das trevas, e não da luz. Nesse sentido, ao adentrar na mente de Levi e expor seus razoamentos, a causalidade apontada pelo narrador sugere um outro sentido para a explicação naturalista da tempestade, como se tivesse sido mesmo por causa das maldições que tudo isso aconteceu, o que é acentuado pela epígrafe do romance e pode dar elementos para pensarmos que o demônio seria um coautor desse romance dentro do romance:

Então Levi berrou:

- Maldito seja, ó Deus!

Ele berrava, com voz roufenha, que se certificara da injustiça do Deus e não mais acreditaria nele.

- Você é surdo! - rosnava Levi. - Se não fosse surdo, teria me ouvido e iria matá-lo neste mesmo momento.

Levi semicerrou os olhos à espera do fogo que deveria descer do céu para fulminá-lo. Isto não aconteceu e Levi continuou a gritar coisas mordazes e ofensivas ao céu sem abrir as pálpebras. Ele exprimia aos brados a sua total desilusão, e a existência de outros deuses e religiões. Sim, um outro Deus jamais admitiria que um homem semelhante a Jeshua fosse queimado até morrer pelo sol num poste.

- Enganei-me! - berrava Levi, já totalmente rouco. - Você é o Deus do mal! Ou os seus olhos estão totalmente vedados pela fumaça que vem das caçoulas, e seus ouvidos não ouvem mais nada exceto as trombetas dos sacerdotes? Você não é um Deus onipotente. Você é um Deus infame. Amaldiçoo-o, oh, Deus dos bandidos, seu protetor e sua alma!

Neste momento algo soprou no rosto do antigo coletor de impostos e farfalhou debaixo dos seus pés. O sopro veio mais uma vez. Então Levi abriu os olhos e viu que por causa das suas maldições, ou por alguma outra razão, tudo no mundo havia mudado. O sol desaparecera antes de atingir o mar em que imergia todas as noites. Uma nuvem carregada o tragara e agora vinha subindo, terrível e inexorável, do oeste. Nas suas margens já fervia a espuma 
branca, na sua barriga negra e fumarenta havia um reflexo amarelo (BULGÁKOV, 1992, p. 195-6, grifo nosso).

A partir de então, Levi experimenta uma sensação de culpa e arrependimento sem par em outras narrativas na história da tradição cristã, que o narrador faz questão de evidenciar, seja para denunciar a fragilidade psicológica e de convicção deste evangelista, seja para, contra a própria vontade de Levi, torná-lo mais humano e menos sacralizado como o escritor do texto sagrado. Com isso, agora passa a dar razão aos argumentos de Berlioz de que o cristianismo seria uma religião inventada como tantas outras e mitologizada a posteriori, ao passar por cima dessas sensações contraditórias que o relato naturalista e não mitologizado revela - pelo que já foi chamado muitas vezes de "realismo":

Levi calou-se procurando compreender se a tempestade que ia cobrir agora Jerusalém alteraria algo no destino do infeliz Jeshua. Quando viu os fios de fogo que retalhavam a nuvem, pôs-se a pedir imediatamente que um relâmpago caísse sobre o poste de Jeshua. Levi olhava arrependido o céu limpo que a nuvem ainda não tinha devorado e onde os abutres começaram a bater mais intensamente as asas para fugir à tempestade, e pensou que tinha se apressado loucamente com as suas maldições. Agora Deus não o ouviria mais (BULGÁKOV, 1992, p. 196).

É importante perceber a proximidade dos trechos em que aparecem sugestões diversas a respeito da realidade ou das causas do real e, com isso, correlatamente, a respeito da noção de sujeito e de verdade. Com efeito, não estamos propriamente diante de um método de representação da realidade que, representando, expõe distintas vozes do discurso sobre modos de representação de sua época para tratar de sua época, mas de um que, como Nietzsche apontou, entende que a realidade depende de como ela é representada, e, por isso, vai buscar a realidade na representação que adota e justapõe os modos de representação que vigoram em sua época. Uma polifonia formal, uma polifonia de métodos de representação e não apenas de vozes de personagens, o que gera uma postura distanciada e crítica em relação àqueles.

Para que isso aconteça, é preciso haver a contraposição dos métodos de representação entre si: são os próprios métodos parodiados que se parodiam entre si, e não eles com uma ideia “original” ou anterior do autor que está parodiando os textos. Por isso, é importante haver mais de um meio a cada vez. Ressalta-se que não se está sugerindo que Bulgákov tenha lido exatamente esses trechos aqui citados, nem seríamos capazes, nem nos interessa comprovar com fatos quais seriam então exatamente os textos que estão sendo contrapostos e usados por Bulgákov, até mesmo porque poderiam muito bem ser falas presenciais que se perderam. Os 
trechos citados valem como uma indicação do tipo de discurso que estava sendo produzido na época - e tomamos "época" de modo esfumaçado, um período de tempo que corresponde a algumas décadas. Mesmo assim, é impressionante a semelhança já apontada de determinadas passagens da narrativa de Pilatos com o que Nietzsche chama de "psicologia do Redentor" será que o Mestre, como historiador, lera $O$ Anticristo de Nietzsche, fazendo seu personagem Pilatos dizer isto?:

\begin{abstract}
- Sei que você [Levi] se considera discípulo de Jeshua, mas vou dizer-lhe que você não aprendeu nada daquilo que ele lhe ensinava. Pois, se fosse assim, você teria que aceitar alguma coisa de mim. Tenha em conta que antes de morrer ele disse que não culpava ninguém - Pilatos ergueu o dedo com um ar significativo, seu rosto estremeceu. - E ele próprio aceitaria certamente alguma coisa. Você é cruel, mas ele não era. (BULGÁKOV,1992, p. 357, grifo nosso).
\end{abstract}

Ou será que ele tomou para si o desafio de Nietzsche de que alguém como Dostoiévski deveria ter vivido entre os primeiros cristãos para descrever sua psicologia, tal como Gógol desenvolvera Almas mortas de uma ideia de Púchkin?

Outra possibilidade é pensar que Nietzsche o tenha ajudado a desenvolver a mentalidade nobre e romana de Pilatos. Nessas alterações que singularizam a narrativa bíblica em $O$ Mestre e Margarida em relação a todas as outras da tradição - embora com elas dialogue do modo particular paródico que aqui analisamos -, talvez fosse possível pensar que quando Levi diz (na citação logo acima) que Deus seria “o Deus do mal!", isso faria com o que o romance do Mestre como um todo, uma vez tendo sido levado à fogueira, fosse considerado uma espécie de invocação do demônio.

Não é demais apontar a proximidade com o personagem Fausto no drama de Goethe quanto a este exercício de interpretação do texto sagrado do cristianismo. Enquanto Fausto faz uma experiência em transposição de mídias, traduzindo a palavra grega palavra (Logos) por Tat (ato), no Gênesis, o Mestre - que já vive a presença do Aufschreibesystem 1900 -, tendo à mão já diversas outras referências sobre o assunto além da Bíblia, experimenta uma tática de representação do real por meio da contraposição de técnicas de representação: ao reescrever a cena da crucificação, parodia os textos da tradição na medida em que explora seus métodos de transposição do real para a representação narrativa:

Auch der einsame Gelehrte verfährt auf dem Papier, das er vollschreibt, wie die Lehrer und Schüler alteuropäischer Universitäten und Lateinschulen, wenn sie klassische oder heilige Texte imitierten und d.h. paraphrasierten. 
Auch auf Fausts Schreibpapier wird das Wort „Wort” nacheinander durch Wörter „Sinn“, „Kraft“, „Tat“ umschrieben und ersetzt. Aber in den Reden, die jenes Schreiben kommentieren, verliert die Umschrift jede rhetorische Rechtfertigung. Die Paraphrasen heißen nicht mehr aus einem Schatz der Tropen und Figuren geschöpft; sie erhalten die umgekehrte Funktion zugesprochen, die wahre und eigentliche Bedeutung eines Wortes zu bedeuten. Und dieses Wort ist ausgerechnet das Wort „Wort”. Es geht nicht um ein Wort oder Signifikat unter anderen; es geht darum, das Wort überhaupt als Signifikanten dem Primat von Signifikaten zu unterstellen. Aus rhetorischen Variationen macht Faust eine semantische Queste nach dem transzendentalen Signifikat. ${ }^{81}$.

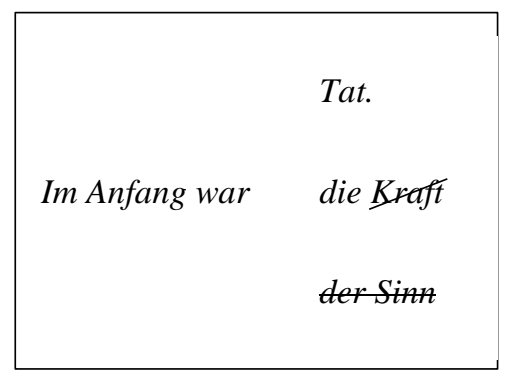

(KITTLER, 2003, p. 18-9).

O texto bíblico serve também aqui para pensar sobre a palavra (e as coisas): a verdade do texto que narra a vida humana de Jesus alegada por Woland como uma experiência literária que busca pensar a relação entre texto e mundo, entre representado e representação.

$* *$

Em contrapartida, não é porque se leva em conta provavelmente o texto nietzschiano, jogandoo contra essas reinterpretações ortodoxas russas, que não se confundiam com a ortodoxia institucional, que nessa narrativa de Pilatos todos os textos da tradição se encontram parodiados. Seguindo a reflexão de Agamben (AGAMBEN, 2014, p. 25 e ss.) sobre as duas linhas divergentes que formam a lenda sobre Pilatos - o que ele chama de lenda branca e a versão

\footnotetext{
81 “Também o sábio solitário procede no papel que ele anota como o professor e o estudante de universidades e escolas de latim da Europa antiga, quando imitavam e - isso quer dizer - parafraseavam textos clássicos ou sagrados. Também no papel em que Fausto escreve a palavra 'palavra' é parafraseada e substituída sucessivamente por palavras como 'sentido', 'força', 'ato [ação]'. Mas nas falas que aqueles escritores comentavam, a reescrita perdia qualquer justificação retórica. As paráfrases não mais significavam criar a partir de um tesouro dos tropos e de figuras; elas receberam a função inversa a elas atribuídas de denotar o significado verdadeiro e autêntico de uma palavra. E essa palavra agora é precisamente a palavra 'palavra'. Não se trata de uma palavra ou significado entre outros; trata-se de atribuir às palavras em geral enquanto significantes o primado de significados. Das variações retóricas, Fausto faz uma busca semântica pelo significado transcendental.". No Quadro, lemos: "No início era a palavra, e sentide, a força, o ato". (Traduções nossas).
} 
histórica de Fílon de Alexandria -, vemos que Bulgákov parece seguir a segunda ${ }^{82}$, mas não só pelo motivo alegado pelo próprio Agamben de que Jesus era um médico das palavras.

Como fica evidente na distinção entre o personagem Mestre e o seu autor, Bulgákov, o efeito que essa prática metodológica gera é inteiramente diferente do que Bakhtin (BAKHTIN, 2013, p. 221), em Problemas da poética de Dostoiévski, chama de traço comum da Icherzählung, do skaz ou da estilização, a saber, a inclusão no plano do autor do discurso do outro voltado para as próprias intenções do autor. Não é que Bulgákov crie um personagem como Bazárov, de Pais e filhos, de Turguêniev, estilizando com isso o discurso do outro, convencionalizando-o ${ }^{83}$, não o colocando em choque com outra voz (que para Bakhtin só pode ser do autor), mas sim é que no próprio processo de criação de um personagem, como Jeshua, diversos discursos de outros são levados em conta e entram em choque, expondo uns aos outros.

Essa prática paródica, assim, não opõe diametralmente o discurso do outro com "o seu agente primitivo" (BAKHTIN, 2013, p. 221), o autor, convertendo "o discurso em palco de luta entre duas vozes" (BAKHTIN, 2013, p. 221). Primeiro, porque estão em jogo mais do que duas vozes. Segundo, porque esse método de representação da realidade põe em jogo as formas de representar a realidade ao pôr como seu conteúdo o real, a verdade e a verossimilhança. Para que haja a disputa entre essas vozes no discurso parodístico dostoievskiano é preciso que tenha sido estabelecido, com a ajuda de algum método de representação da realidade, esse palco de luta, o que pode ser entendido como o estabelecimento de critérios de verdade e definições do que é real. Mesmo que não sejam definitivos, mesmo que sejam relativos aos discursos, que possam estar em forma onírica ou em primeira pessoa, como um relato do qual podemos duvidar de sua adequação com a autêntica realidade, é preciso que essas duas vozes do discurso compartilhem seus critérios de real e de verdade, que debatam a partir de um mesmo critério que os põe na mesma dimensão.

É uma reviravolta que consiste em ir do método de representação polifônico para a polifonia dos métodos de representação. As obras de Dostoiévski de fato "impressionam pela insólita variedade de tipos e modalidades de discurso" (BAKHTIN, 2013, p. 233), mas, com

\footnotetext{
${ }^{82}$ Bulgákov conhecia Fílon, o que passa desapercebido por Agamben. Ver: "Bulgákov devia conhecer essa versão, porque, em sua narrativa, Pilatos se dirige obstinadamente a Jesus como a um médico" (AGAMBEN, 2014, p. 29); e em Bulgákov, "cumpre assinalar que o redator [Berlioz] era uma pessoa culta e se referia muito habilmente nas suas considerações a historiadores da Antiguidade, por exemplo, o famoso Fílon de Alexandria e o brilhante erudito Flavius Josephus [...]" (BULGÁKOV, 1992, p.14).

${ }^{83}$ Bakhtin afirma que nessas formas composicionais "A ideia do autor não entra em choque com a ideia do outro, mas a acompanha no sentido que esta assume, fazendo apenas esse sentido tornar-se convencional" (BAKHTIN, 2013, p. 221).
} 
isso, não se coloca somente o problema de encontrar "a última instância semântica do autor", como pergunta Bakhtin, mas também se, por exemplo, ainda faz sentido preservar a noção de autoria como a preservação da noção de sujeito clássica da filosofia. Isso porque a representação de vozes do discurso que se interpõem, e, mais especificamente, uma voz que se contrapõe à do autor, pressupõe que cada voz e o autor sejam compreendidos como unidades-sujeitos, mesmo que fragmentadas, sendo perpassadas por outras vozes que as constituem.

O método de representação polifônico se caracteriza, assim, pela necessidade da estabilização do palco do jogo - entendido como as regras que limitam o espaço do jogo e o instauram, ou seja, como os critérios de verossimilhança entre representação e realidade - e da noção de sujeito. Essa necessidade não é por acaso, uma vez que a noção de verdade tradicional está erguida na ideia da adequação de sujeito e predicado. Por mais que Bakhtin aponte para a diluição da autoria no dialogismo de Dostoiévski, essa diluição da autoria só pode ocorrer se preservar a própria noção de autoria que está sendo diluída.

Ao operar essa reviravolta para a polifonia de métodos de representação da realidade, Bulgákov põe a autoria em questão, e, com isso, a verdade e o palco do jogo. É nesse sentido que podemos entender a afirmação de Weir de que $O$ Mestre e Margarida põe concepções rivais de autoria uma contra a outra, sendo, com isso, diferente de muitos outros romances modernos que colocam o texto não como verdade, mas como ficção, porque nele a literatura é posta "As a possible truth but also self-aware of the limitations of fiction" ${ }^{84}$ (WEIR, 2002, p. 36). Bulgákov não toma uma posição nessa questão porque sua intenção reside não em resolvê-la, mas em explorá-la: para Weir, é nessa "Contradictory attempt both to render the truth in fiction and to remind us that fiction cannot represent experience transparently [that] Bulgakov incorporates three different views of authorship in The Master and Margarita" ${ }^{85}$ (WEIR, 2002, p. 36).

Weir identifica a primeira concepção de autoria posta em jogo no romance como uma noção tradicional, "realista", de autoria, uma que entende a literatura como mimesis e que para ele está presente em alguns aspectos do romance do Mestre. Nesta, há uma divisão forte entre texto e autor que evidencia uma concepção epistemológica de sujeito e objeto que organizam a criatividade literária. As palavras se referem a coisas mundanas e o status ontológico dessas coisas nunca é posto em questão. A segunda, ele entende como uma concepção hermenêutica,

\footnotetext{
84 “[...] Como uma verdade possível, mas também autoconsciente das limitações da ficção.” (Tradução nossa).

85 “[...] Tentativa contraditória de igualmente dizer a verdade na ficção e nos lembrar que a ficção não pode representar a experiência de modo transparente [que] Bulgákov incorpora três diferentes visadas de autoria em $O$ Mestre e Margarida." (Tradução nossa).
} 
que aproxima a ideia de autor com a de herói, pensando que a autoria é capaz de restaurar a subjetividade e dar vida ao mundo. Weir afirma que nesta concepção a autoria é vista como um modelo potencial para a compreensão da essência da personalidade humana. Já a terceira, e mais significativa para nós aqui, é denominada de metacrítica, na qual o autor se mostra consciente de que para ser compreendido ele precisa levar em conta os textos que foram ditos antes dele. Embora Weir não dê tanto crédito para o segundo significado de autoria enquanto metacrítica, esse pode ser visto como a consequência última do primeiro. Nele fica explicitado onde encontrar o autor no procedimento paródico de Bulgákov em O Mestre e Margarida, a saber, nem tanto na autoria das fofocas e estórias, mas naquilo que se forma a partir delas:

[Authorship as metacritical] is more like a self-conscious speaker of the strange language called literature. Aware that his ability to speak and be understood depends wholly on the fact that others have spoken before him, the metacritic poses as a parodist who sometimes tries to make fun of and sometimes defers to tradition.

Authorship in this metacritical sense is least like a model of personality. Here the author suggests that he is not so much the creator of the work of literature as he is created by it. Thus the narrator is not himself a rumormonger, he is merely the product of so many rumors in the novel. Parody is not an authorial device so much as it is the revelation of the inherent dependency of literary texts on one another (and here we see the postmodern appeal of The Master and Margarita). ${ }^{86}$ (WEIR, 2002, p. 36).

Nesse sentido, não se trata de conjugar a posição primária do autor como uma voz ao lado das outras vozes, mas de vê-la como o resultado final desse jogo de contraposição de textos uns com outros. Ao mesmo tempo, isso não significa uma monologia, porque não há um a priori do autor guiando esse jogo, mas sim as regras do jogo, ou seja, a própria necessidade interna das vozes contrapostas segundo essa polifonia de métodos de representação é que determinará o rumo que esse jogo irá tomar. A autoria aqui só pode ser algo bem diferente do que classicamente se compreende por sujeito: a autoria como metacrítica só pode ser uma contraautoria, uma autoria que expõe a verdade da autoria tradicional como paródia.

\footnotetext{
86 "[Autoria como metacrítica] é mais parecida com um falante autoconsciente da estranha linguagem chamada literatura. Consciente de que sua habilidade de falar e de ser entendido depende completamente do fato de que outros tenham falado antes dele, o metacrítico posa como um parodista que ora tenta fazer piada da tradição, ora defendê-la. Autoria nesse sentido metacrítico é menos parecida com um modelo de personalidade. Aqui, o autor sugere que ele não é tanto o criador da obra de literatura quanto ele é criado por ela. Assim, o narrador não é ele mesmo um fofoqueiro, mas meramente o produto de tantas fofocas na novela. Paródia não é tanto um dispositivo autoral quanto é a revelação de dependência inerente de textos literários uns com outros (e aqui podemos ver o apelo pós-moderno de $O$ Mestre e Margarida).” (Tradução nossa).
} 
Assim, também é possível falar de uma busca por um contramétodo de representação da realidade em $O$ Mestre e Margarida. O discurso do outro não aparece mediado por um personagem representado no romance, ou por um narrador que organiza a polifonia, mas esses são expressão de um contramétodo capaz de expor os critérios de verdade dos quais os outros métodos dependem para sustentar o discurso de um outro ou desse narrador que organiza a polifonia.

Se, diz Hal Foster, Lacan define o traumático "como um encontro faltoso com o real", então o "real não pode ser representado; só pode ser repetido; aliás, tem de ser repetido" (FOSTER, 2013, p. 128). O uso da repetição por Warhol, para Foster, não tem a função de representar nem de simular, mas de proteger o real compreendido como traumático. A paródia em $O$ Mestre e Margarida também parece ter ligação com uma experiência passada traumática, ou com uma nostalgia de um real passado, mas, a partir dessa experiência do real como traumático, a paródia que põe em jogo diversas concepções de sujeito e de métodos de representação da realidade acaba se abrindo para a metaquestão sobre o que é, afinal, o real.

$* *$

Há muito não dito em $O$ Mestre e Margarida. Por que essa motivação imperiosa do Mestre de escrever sobre o funcionário da administração romana ${ }^{87}$, Pilatos? Talvez porque o historiador Mestre percebeu igualmente que Pilatos "é [...] a única figura a dar testemunho histórico dos eventos messiânicos ligados a Jesus" (AGAMBEN, 2014, p. 8) e que, com ele, "os evangelistas revelam, talvez pela primeira vez, algo parecido com a intenção de construir um personagem, com psicologia e idiomatismo próprios" (AGAMBEN, 2014, p. 23). Também é na narrativa de Pilatos que não só ouvimos falar, mas acompanhamos a ação da polícia secreta em seus detalhes. Mais do que isso, talvez o que mais é significativo nesse episódio é o diálogo tergiversado e dissimulado entre o funcionário Pilatos e Afranius, o chefe da Guarda Secreta romana, em que as reais intenções nunca são explicitamente ditas: até mesmo Pilatos fica sem saber explicitamente qual o artifício que Afranius utilizou para atrair Levi para fora dos muros da cidade.

\footnotetext{
${ }^{87} \mathrm{Na}$ apresentação do texto de Agamben, Vinícius N. Honesko pergunta: "Todavia, qual é a razão de o filósofo [Agamben] sentir tal obrigação? Por que essa motivação imperiosa por investigar esse funcionário da administração romana?" (AGAMBEN, 2014, p. 7).
} 
Além de sugerir um potencial de controle e vigilância do Estado romano que só a tecnologia moderna seria capaz de possibilitar aos Estados modernos, anacronia que delata a época e o lugar do autor do texto, esse diálogo também se soma e se contrapõe às outras situações dialogais do romance, com o que se explora ainda em mais um tipo de diálogo as relações entre discurso, coragem, verdade, ficção, responsabilidade e poder. $\mathrm{O}$ assassino de Judas, chefe da Guarda Secreta, uma das instituições chaves para caracterizar um Estado como totalitário (permitam-me usar esta palavra, seguindo a anacronia do romance), se aproveita dos poderes dessa instituição para assassinar Judas, aquele que traiu Jesus, ou seja, para fins pessoais, e não estatais. Tendo já cometido o ato, fala baixo, talvez com medo da presença de outros serviços secretos, explicando suas suposições sobre quem teria cometido o assassinato de Judas (que ele mesmo cometeu) e, com isso, ao mesmo tempo em que não explicita sua real participação no ocorrido, cria racionalmente uma narrativa para sustentar que um outro teria cometido o ato:

- Não admito em hipótese alguma a idéia - dizia Afranius, baixinho - de que Judas tivesse deixado que pessoas suspeitas o apanhassem dentro da cidade. É impossível esfaquear uma pessoa secretamente numa rua. Logo, devem têlo atraído a um canto qualquer. Mas o nosso serviço já o procurou na Cidade Baixa e, se ele estivesse lá, sem dúvida, o teria encontrado. Mas ele não se acha na cidade, posso garantir isso. Se tivesse sido assassinado longe da cidade, o pacote de dinheiro não seria lançado tão rápido no palácio do sumo sacerdote. Ele foi assassinado nas proximidades da cidade. Conseguiram conduzi-lo ardilosamente a um local propício.

- Não compreendo como se pode fazer isso.

- Com efeito, procurador, esta é a questão mais difícil de todo o caso; não sei se conseguirei resolvê-la.

- Realmente, é um mistério! Numa noite de festa, um crente, não se sabe por que, sai da cidade, abandonando a ceia de Pessach, e morre distante das festividades. Quem e de que maneira conseguiu atraí-lo? Não seria uma mulher? - perguntou de repente o procurador, com um ar inspirado.

Afrânio respondeu calma e ponderadamente:

- Em hipótese alguma, procurador. Essa possibilidade está totalmente excluída. É preciso raciocinar de uma forma lógica. (BULGÁKOV, 1992, p. $350)$.

Mas também pode ser que essa motivação imperiosa de se voltar sobre a figura de Pilatos se deva também não à condição humana, como para Agamben, entre o reino do temporal e do eterno, da qual o procurador romano é a encarnação nas narrativas evangélicas (AGAMBEN, 2014, p.58), mas ao humano entendido não apenas como a partir da razão, mas também da ficção. Pilatos pode ser, assim, a encarnação do problema humano da representação 
que perpassa todo $O$ Mestre e Margarida como uma obra que expõe o humano entre realidade e fantasia por meio da polifonia de métodos de representação do real. 


\section{Considerações finais}

Ao longo deste estudo, abordamos $O$ Mestre e Margarida a partir de três grandes temáticas: as questões relativas à história e à sociedade que surgem de uma leitura ingênua do primeiro capítulo da obra; a passagem de um capítulo ao outro, o entremeio, a partir do que tematizamos centralmente o fáustico, o procedimento paródico e a união entre os romances; e, por fim, o segundo capítulo, o romance dentro do romance sobre Jesus Cristo e Pôncio Pilatos.

Esse esquema baseado nos capítulos de $O$ Mestre e Margarida já expõe as intenções e os escopos de nosso estudo: nunca foi o caso de acharmos que seríamos capazes de realizar uma leitura total do romance, como se fôssemos dar conta de todos os seus pormenores. Ao contrário, limitamos o problema a esses três momentos.

Ao mesmo tempo, também não se trata de uma limitação estrita, como se não pudéssemos falar do tema central do segundo capítulo no primeiro, ou voltar a questões relativas ao primeiro no terceiro; mas sim que o que estava em questão em um momento era ora este, ora aquele tema. Por isso, muitas vezes vimos a necessidade de retomar uma parte do romance ou de alguma análise para nós importante ou de adentrar em temas que seriam mais profundamente tratados posteriormente. Vimos esses rodeares não como uma mera repetição, mas sim como uma circunvolução a partir de um outro ponto do círculo capaz de lançar luz a esse mesmo ponto de diversos modos, a partir de outro percurso de pensamento. Esse foi o caso de temas como o da paródia e da ética, temas que obsessivamente retornavam em nossas análises.

Ocorre que mesmo dentro daquilo que abordamos neste texto ficou muito ainda por se falar e aprofundar. Este é o caso em todos os três momentos, mas talvez principalmente do último, cujo material coletado - lido, fichado, refletido - em muito ultrapassou o que foi possível tratar nessas páginas. Por isso volto aqui a afirmar o que escrevi na introdução: este último capítulo, que no projeto de mestrado original talvez fosse pensado como o centro do trabalho - uma investigação sobre a presença de aspectos da filosofia alemã na década de 1920 e 1930 russa a partir da análise do romance de Bulgákov (e que diluo em linhas gerais nos dois primeiros capítulos) -, acabou sendo um ponto de chegada, e não de partida. Gostaríamos de ter nos aprofundado mais na relação comparada de $O$ Mestre e Margarida com a história das ideias na Rússia que privilegiava a discussão sobre o humano, deus, o niilismo, a ética etc., principalmente em autores para nós mais relevantes como Berdiaev, Chestov e Florenski. 
Mesmo a relação com Bakhtin fomos capazes apenas de apontar alguns dos seus traços principais.

Em sua concepção, este estudo foi pensado como parte de uma questão mais ampla a respeito da relação entre filosofia e literatura que envolvia um engajamento no estudo de filosofias não ocidentais que comecei a desenvolver em uma iniciação científica no fim da graduação. Acreditava ter visto no romance de Bulgákov um momento privilegiado em que essa relação - se bem que ressoando toda uma tradição que Bakhtin não nos deixa esquecer ocorreu de modo único na história da filosofia contemporânea (aquela a partir da segunda metade do século XIX) e na arte e na literatura modernas (que data do mesmo período), talvez pela especificidade do momento e lugar histórico de Bulgákov e desses outros autores teóricos. Bakhtin e Bulgákov são atores muito particulares para esse momento, pois embora trouxessem uma aparência de crítica conservadora às posições vistas então como as mais radicais, seus posicionamentos eram na verdade bem mais complexos do que - para dizer com todas as letras - o aparente fundo religioso de algumas de suas colocações ou temáticas fazem parecer, o que ao meu ver os diferencia explicitamente deles.

Acredito que ao longo deste estudo essa questão esteve sempre presente, latente, em todas as análises da obra de Bulgákov e dos escritos de Bakhtin. Quando Bakhtin fala em "responsabilidade" como aquilo capaz de intermediar arte e vida; essa palavra com fundo religioso e cristão ortodoxo inegável na verdade pode estar relacionada a uma postura extremamente complexa como a da prática parresiástica e da tradição cínica, como uma postura capaz de resolver o problema da separação entre teoria e prática para além de conceitos e termos que dependem de uma noção de verdade tradicional que não é capaz de abordar o problema do critério de verdade levando em conta o lugar de poder da fala que se diz verdadeira. Em outras palavras: Bakhtin teria sabido levar algumas discussões do ambiente teológico das primeiras décadas do século XX russo para problemas universais filosóficos - e foi justamente essa vontade de dialogar com uma história mais larga da tradição ocidental e com a filosofia propriamente dita que me interessou em seus primeiros textos. E vai na mesma linha o romance de Bulgákov: o capítulo inicial - era isso que procurávamos investigar! - de $O$ Mestre e Margarida parece abordar essa questão de modo extremamente consciente, sub-repticiamente às questões filosóficas sobre o que os aparentes diálogos se davam - diálogos vazios e satirizados, cujo tema só poderia estar mesmo em outro lugar -, ao mesmo tempo em que promove uma inflexão levando esse problema ao do real e da representação do real. 
Aqui é interessante perceber como isto ao mesmo tempo é extremamente moderno como percebe Weir, como vimos, afirmando não ver nessa tematização de si mesmo, como uma ficção e não como verdade, nada de muito inovador no romance -, e também uma profunda resistência nostálgica ao moderno apontando ao mesmo tempo não para uma volta, que já se percebia impossível, mas para um outro lugar que poderia - a todo tempo de nosso estudo nossa questão era se realmente seria capaz disso - desfazer essa dicotomia de tal modo que nos obrigasse a reestruturar nossas categorias e relações entre conceitos.

Daí nosso interesse inicial no romance e na relação do romance com o que se chama comumente de nietzschianismo russo, pois, como já foi dito, a abordagem da história das ideias da década de 1880 até a de 1930 na Rússia e na URSS a partir da relação das múltiplas vozes com Nietzsche era capaz de embaralhar e reestruturar para nós os seus cortes ideológicos mais ou menos estanques e já saturadamente repetidos. E posteriormente nosso interesse na relação possível entre Bakhtin e alguns aspectos da tradição cínica era capaz de sugerir que Bakhtin e, por consequência, Bulgákov embora estivessem inseridos no contexto de uma discussão teológica por ocasião do virulento ataque contra a religião que ocorria no âmbito da Revolução Russa -, podem apontar - talvez sem perceber e até mesmo sem querer isso - para outros contextos que extrapolam os problemas internos das querelas e disputas dentro do cristianismo e deste contra os não cristãos. Outro exemplo foi a necessidade que sentimos de nos determos no estudo da paródia, pois nesse estudo formal poderíamos encontrar o procedimento ou mecanismo capaz de sustentar estas suposições.

Neste momento - nisso que deveria ser o mais próximo possível de uma conclusão em que se espera uma tese definitiva aqui do tipo sim ou não -, o que posso fazer é apontar, como estava tentando fazer no começo desta conclusão, para o caráter inesgotável dessa circunvolução, e para como talvez eu tenha antes circunvolvido essas questões em potência, e nem tanto (como havíamos querido) em ato. Ao mesmo tempo, esse se preparar para a viagem assoma-me já como um viajar. Não vem ao caso lembrar da defesa da reflexão sedentária de Descartes, um baluarte da modernidade cosmopolita, contra o nomadismo daquele que viaja e não conhece a si mesmo; só o vem talvez apenas para relacionar isso ao âmbito dos estudos das filosofias e literaturas não ocidentais, ressalvando o perigo de se imaginar encontrar nessas outras filosofias não apenas o exótico e o exotérico, mas também a possibilidade de uma fuga de si, como se elas pudessem nos levar ao abismo de nós mesmos, ou às fronteiras e limites do pensamento. Embora estudar esse período histórico tenha me parecido relevante pelo potencial de deslocar estruturas e categorias tradicionais do pensamento filosófico e literário, esse 
potencial me interessava pelo seu caráter de encontro e embate com a filosofia dita ocidental, o mesmo que me atraiu na iniciação científica no estudo da noção de nada em alguns autores da Escola de Kyoto.

Quem traça uma relação entre ambos os contextos, o russo e o japonês, é Botz-Bornstein (2008) indicando a proximidade de ambos em suas discussões sobre fé e razão. Estes seriam, para ele, os dois contextos não ocidentais a desenvolver filosofia "em sentido ocidental", embora eu preferiria falar nos dois contextos que fazem filosofia na época (que na filosofia institucionalizada chamamos de) contemporânea em diálogo intenso com a tradição europeia nesse momento já institucionalizada - é verdade que não são os únicos contextos, já que poderíamos ver os autores do pragmatismo americano como produzindo filosofia na periferia do centro da produção filosófica e institucional do século XIX. Essa proximidade, no entanto, é ainda maior na medida em que está preocupada em pensar a relação entre a filosofia particular e universal, a questão da técnica (aliada com a da razão) como um modo de pensar a dominação pela técnica e das mudanças nos modos de vida e de concepção de humano e de sujeito.

Nesse contexto de filosofias da desconstrução da tradição dita ocidental e de encontro com filosofias não europeias, surge a possibilidade de uma reapropriação de tradições que foram marginalizadas desde a Antiguidade pela filosofia ocidental tradicional e que podem dar a chave pela qual o embate entre as filosofias localizadas podem se dar. É o caso do encontro de Nishida com certa tradição dita mística ocidental, como Plotino e Mestre Eckhart e com o pragmatismo americano (como disse, então ainda periférico no contexto da filosofia ocidental), e também de Bakhtin com a cultura carnavalesca e o que ele chama de sátira menipeia (ao mesmo tempo, ambos são formados no contexto da filosofia europeia neokantiana e dialogam explicitamente com esta). Foi também com o intuito de ressaltar essa dinâmica típica da filosofia contemporânea que expusemos a preocupação filosófica de Bakhtin para poder sugerir a possibilidade de uma aproximação sua com o último Foucault que, embora no centro da filosofia europeia, se debruça também sobre tradições periféricas da filosofia europeiaocidental, ao reinterpretar o diálogo socrático a partir de certa ética cínica. O que nos interessava era sugerir que o interesse de Bakhtin no diálogo socrático e em certa tradição cínica também ocorria por um interesse em um problema sobretudo ético (que encontramos, como já disse, já em seu primeiro texto sobre a responsabilidade); ao mesmo tempo em que essa aproximação é capaz de tornar esse problema ético de Bakhtin mais complexo, a ponto de uma crítica como a de Safatle elaborada a partir de certa ideia de moderno e de razão de Adorno não fazer efeito sobre ele quando visto sob esta perspectiva. 
Esses temas foram envolvidos neste texto conforme a análise de $O$ Mestre e Margarida pedia e permitia: desde a aproximação com o romance realista socialista já está colocada a questão da paródia, cuja particularidade em Bulgákov nos abriu caminho para perseguir, no horizonte, essas outras paragens. A expressão do título do último capítulo, Jesus-rebus-Pilatos, aponta exatamente para uma das intersecções entre essas duas paragens, na medida em que sugere que Jesus(-Pilatos) funciona como uma figura pato-coelho muito mais complexa do que o pato-coelho, na medida em que Bulgákov faz uso, com ajuda de um tipo de procedimento paródico, do fato de Jesus-Pilatos poder não apenas ser pato, coelho ou pato-e-coelho, mas outras possibilidades de que a dualidade do pato-coelho figurativo não dá conta, algumas das quais histórico-interpretativas. É claro que Bulgákov não joga com todas elas, mas percebe que Jesus funciona como um meio para pôr diversos mundos em conflito e em ressonância no nível pré-objetivo do romance, ou seja, não fazendo com que seus personagens tematizem sobre isso, mas concebendo o romance desse conflito ressonante. $\mathrm{O}$ real ocorre a partir do conflito de interpretação de Jesus-rebus-Pilatos no meio entre pato-coelho, no espaço em branco entre um capítulo e outro, entre uma letra e outra, que entrevê um horizonte ético num ambiente em que o critério do que é verdadeiro e do que é real foi tornado valor. Nesse sentido, a noção de humano em relação a um tal real se contrapõe à do novo humano do realismo socialista, mas ao mesmo tempo não meramente se opõe a ela, nem se apresenta como uma mera volta a algo já existente. Ao contrário, parece mais bem ser uma noção ao mesmo tempo mais simples e mais complexa: uma espécie de Übermensch que não é superhumano, mas está sobre (no) humano ao pôr em jogo o fantástico ao lado da racionalidade que tradicionalmente define o ser do humano. 
Referências Biliográficas

Esta bibliografia contém referências relevantes para os problemas abordados ao longo da dissertação e que não foram necessariamente citados.

AGAMBEN, G. Pilatos e Jesus. São Paulo: Boitempo Editorial, 2014.

ANDRADE, H. F. de. Materiais para um estudo do cubo-futurismo russo. Dissertação de mestrado. Faculdade de Filosofia Letras e Ciências Humanas da Universidade de São Paulo, São Paulo, 1986.

ANDRADE, H. F. de, O diabo solto em Moscou. São Paulo: Edusp, 2002.

ANDRADE, H. F. de, O realismo socialista e suas (in)definições. Literatura e Sociedade, São Paulo, n. 13(1), p. 152-165, 2010a.

ANDRADE, H. F. de. Apontamentos sobre a prosa satírica de Mikhail Bulgákov. In: BULGÁKOV, M. Coração de cachorro e outras novelas. São Paulo: EDUSP, 2010b. p. 245-299.

BAKER, H. D. Socratic, Hermetic, and Internally Convincing Dialogue: Types of Interlocution in Bulgakov's "The Master and Margarita". Russian Review, Kansas, v. 57, n. 1, p. 53-71, 1998. Disponível em:_http://www.jstor.org/stable/131691. Acesso em: 16 mar. 2017.

BAKHTIN, M. M. A cultura popular na Idade Média e no Renascimento: O contexto de François Rabelais. Tradução de Yara Frateschi. $4^{a}$ ed.. São Paulo: Hucitec, 1999.

BAKHTIN, M. M. O Problema do conteúdo, do Material e da Forma na Criação Literária. In: BAKHTIN, M. M. Questões de literatura e de estética (a Teoria do romance). São Paulo: HUCITEC, 2010.

BAKHTIN, M. M. Problemas da poética de Dostoiévski. Tradução e notas de Paulo Bezerra. Rio de Janeiro: Forense Universitária, 2013.

BAKHTIN, M. M. Estética da Criação Verbal. Tradução de Paulo Bezerra. São Paulo: WMF Martins Fontes, 2015.

BARRATT, M. Between Two Worlds: A Critical Introduction to The Master and Margarita. Oxford: Clarendon Press, 1987.

BARRATT, M.. Beyond Parody: The Goethe Connection. In: WEEKS, L. D. (Org.). The Master \& Margarida: A Critical Companion. Evanston: Northwestern University Press, 1996.

BERDYAEV, N. Dostoievsky: An Interpretation. Tradução de Donald Attwater. Nova York: Semantron Press, 2009a.

BERDYAEV, N. The destiny of Man. Tradução de Natalie Duddington. 3a ed.. San Rafael: Semantron Press, 2009b.

BERDYAEV, N. Slavery \& Freedom. Tradução de R. M. French. 2a ed.. San Rafael: Semantron Press, 2009c.

BERLIN, I. Pensadores Russos. Tradução de Carlos Eugênio Marcondes de Moura. São Paulo: Companhia das Letras, 1988. 
BERLIN, I. Estudos sobre a humanidade: Uma antologia de ensaios. Tradução de Rosaura Eichenberg. São Paulo: Companhia das letras, 2002.

BERNARDINI, A. F. "O evangelho segundo jesus cristo e o evangelho segundo judas". Revista eletrônica Zunai, São Paulo, out. 2010.

BINSWANGER, H. C. Dinheiro e magia. Rio de Janeiro: Jorge Zahar, 2011.

BLOK, A. Catiline: A page from History of World Revolution. In: ROSENTHAL, B. G.; BOHACHEVSKY-CHOMIAK, M. (Orgs.). A Revolution of the Spirit: Crisis of Value in Russia, 1890-1924. New York: Fordham University Press, 1990. p. 293-320.

BLOK, A. Os doze. In: Poesia Russa Moderna. Tradução de Haroldo de Campos, Boris Schnaiderman Augusto de Campos. São Paulo: Perspectiva, 2001. p. 61-78.

BOTZ-BORNSTEIN, T. Russian and Japanese Philosophies: A Comparative Study. Philosophical Frontiers, v. 3, n. 1, p. 65-85, 2008.

BULGAKOV, M. El Maestro y Margarita. Madrid: Alianza Editorial, 1990.

BULGÁKOV, M. O Mestre e Margarida. São Paulo: Ars Poética, 1992.

BULGÁKOV, M. Romanzo Teatrale: Le memorie di um defunto. Milão: BUR Rizzoli, 2007.

BULGÁKOV, M. Um coração de cachorro e outras novelas. Tradução e notas de Homero Freitas de Andrade. São Paulo: Editora da Universidade de São Paulo, 2010.

CAMPOS, H. D. Deus e o diabo no Fausto de Goethe: Marginália fáustica (leitura do poema, acompanhada da transcrição em português das duas cenas finais da segunda parte). São Paulo: Perspectiva, 2005.

CANDIOTTO, C. Foucault e a crítica da verdade. Belo Horizonte: Autência, 2010.

CAVALIERE, A.; VÁSSINA, E.; SILVA, N. (Orgs.). Tipologia do simbolismo nas culturas russa e ocidental. São Paulo: Associação Editorial Humanitas, 2005.

CHESTOV, L. La Philosophie de la tragédie: Dostoïewsky et Nietzsche. Tradução de B. de Schloezer. Paris: Éd. J. Schiffrin, Éditions de la Pléiade, 1926.

CHULKOV, G. On Mystical Anarchism. In: ROSENTHAL, B. G.; BOHACHEVSKY-CHOMIAK, M (Orgs.). A Revolution of the Spirit: Crisis of Value in Russia, 1890-1924. Nova York: Fordham University Press, 1990. p. 177-86.

CLARK, K. The Soviet Novel: History as Ritual. $3^{\text {a }}$ ed.. Bloomington: Indiana University Press, 2000.

CLARK, K.; HOLQUIST, M.. Mikhail Bakhtin. Cambridge e Londres: Harvard University Press, 2014.

CLARK, T. J. God Is Not Cast Down. In: Farewell to an Idea: Episodes from a History of Modernism. New Haven: Yale University Press, 1999. p. 225-289.

CURTIS, J. A. E. Bulgakov's Last Decade: The Writer as Here. Cambridge: Cambridge University Press, 1987. 
DABEZIES, A. Le Mythe de Faust. Paris: Librairie Armand Colin, 1972.

DERRIDA, J. Essa estranha instituição chamada literatura: uma entrevista com Jacques Derrida. Belo Horizonte: Editora UFMG, 2014.

DIKOVA-MILANOVA, M. Bulgakov's The Master And Margarita and the Illusions of Kant's Speculative Reason. Russian Literature, v. LXXIV, n. III/IV, p. 275-303, 2013.

DOSTOIÉVSKI, F. O idiota. Tradução de Paulo Bezerra. São Paulo: Editora 34, 2002.

EDWARDS, T. R. N. Three Russian Writers and the Irrational: Zamyatin, Pil'nyak, and Bulgakov. Cambridge: Cambridge University Press, 1982.

FLORENSKIJ, P. A. Il valore magico della parola. Tradução e organização de Graziano Lingua. Milão: Edizioni Medusa, 2003a.

FLORENSKIJ, P. A. La prospettiva rovesciata e altri scritti. Tradução de Carla Muschio e Nicoletta Misler. Roma: Gangemi Editore, 2003b.

FLORENSKIJ, P. A. La colonna e il fondamento della verità: saggio di teodicea ortodossa in dodici lettere. Milão: Mimesis Edizioni, 2012a.

FLORENSKIJ, P. A. Lo spazzio e il tempo nell'arte. $4^{\text {a }}$ ed.. Tradução e organização de Nicoletta Misler. Milão: Adelphi Edizioni, 2012b.

FLORENSKIJ, P. A. Attualità della parola: La lingua tra scienza e mito. $3^{\mathrm{a}}$ ed.. Tradução e organização de Elena Treu. Milão: Edizioni Angelo Guerini e Associati, 2013.

FLORENSKIJ, P. A, BELYJ. A., L'arte, il simbolo e Dio: Lettere sullo spirito russo. Tradução e organização de Giuseppina Giuliano. Milão: Edizioni Meduza, 2004.

FLUSSER, V. Wie man philosophiert in Brasilien? In: FLUSSER, V. Schrifte. Band 4.Brasilien oder die Suche nach dem neuen Menschen: Für eine Phänomenologie der Unterentwiklung. Mannheim: Bollmann Verlag, 1994.

FOSTER, H. O retorno do real. Tradução de Célia Euvaldo. São Paulo: Cosac Naify, 2013.

FOUCAULT, M.. As palavras e as coisas: uma arqueologia das ciências humanas. $9^{a}$ ed.. Tradução de Salma Tannus Muchail. São Paulo: Martins Fontes, 2007.

FOUCAULT, M. A coragem da verdade: O governo de si e dos outros II. Tradução de Eduardo Brandão. São Paulo: Editora WMF Martins Fontes, 2011.

FRANK, J. Pelo prisma russo: Ensaios sobre literatura e cultura. Tradução de Paula Roc Rolim e Francisco Achcar. São Paulo: EDUSP, 1992.

FRANK, J. Dostoiévski: O manto do profeta, 1871-1881. Tradução de Geraldo Gerson de Souza. São Paulo: Editora da Univerdade de São Paulo, 2007.

FRANK, J. Dostoiévski: As sementes da revolta, 1821-1849. Tradução de Vera Pereira. São Paulo: Editora da Univerdade de São Paulo, 2008. 
FRANK, J. Between Religion and Rationality: Essays in Russian Literature and Culture. Princeton: Princeton University Press, 2010.

FRANK, J. Dostoiévski: Os anos de provação - 1850 a 1859. Tradução de Vera Pereira. São Paulo: Editora da Univerdade de São Paulo, 2012.

FRANK, J. Dostoiévski: Os anos milagrosos, 1865 - 1871. Tradução de Geraldo Gerson de Souza. São Paulo: Editora da Univerdade de São Paulo, 2013a.

FRANK, J. Dostoiévski: Os efeitos da libertação, 1860-1865. Tradução de Geraldo Gerson de Souza. São Paulo: Editora da Univerdade de São Paulo, 2013b.

GIACOIA JUNIOR, O. Nietzsche como psicólogo. São Leopoldo: Editora UNISINOS, 2006.

GIACOIA JUNIOR, O. Nietzsche: o humano como memória e como promessa. Petrópolis: Vozes, 2013.

GOETHE, J. W. Fausto: uma tragédia, primeira parte. Tradução de Jenny Klabin Segall. São Paulo: Editora 34, 2008a.

GOETHE, J. W. Fausto: uma tragédia, segunda parte. Tradução de Jenny Klabin Segall. São Paulo: Editora 34, 2008b.

GÓGOL, N. Almas mortas. Tradução de Tatiana Belinky. São Paulo: Perspectiva, 2008.

GRILLAERT, N. What the God-seekers Found in Nietzsche: The Reception of Nietzsche's Übermensch by the Philosophers of the Russian Religious Renaissence. Amsterdã; Nova York: Rodopi, 2008.

GROYS, B. Friedrich Nietzsche, Michail Bachtin, Michail Bulgakow. In: Anti-Philosophie. Munique: Carl Hanser Verlag, 2009.

Einführung in die

GROYS, B. Friedrich Nietzsche, Michail Bachtin, Michail Bulgakow. In: Introdução à antifilosofia. Tradução de Constantino Luz Medeiros. São Paulo: EDIPRO, 2013. p. 151-192.

HEIDEGGER, M. A palavra de Nietzsche: 'Deus morreu' (1943). In: Caminhos da Floresta. Tradução de Alexandre Franco de Sá. Lisboa: Calouste Gulbenkian, 2002.

HEIDEGGER, M. Holzwege, Gesamtausgabe (GA) 5. Frankfurt: Vittorio Klostermann Verlag, 2003.

HEIDEGGER, M. Ser e Tempo. Tradução de Fausto Castilho. Campinas: Editora UNICAMP, 2012.

HERZOG, W. Caminhando no gelo. Tradução de Lúcia Nagib. Rio de Janeiro: Paz e Terra, 1982.

HERZOG, W. Vom Gehen im Eis. Frankfurt am Main: Fischer Verlag GmbH, 2009.

IGNATOW, A. Feind Oder Zeuge Des Glaubens? Nietzsche im Spiegel der Russischen Religiösen Philosophie. Studies in East European Thought, v. 55, n. 3, p. 217-245., 2003.

KITTLER, F. Aufschreibesysteme 1800/1900. München: Fink Verlag, 2003.

KLINGER, G. Escritas de si, escritas do outro: autoficção e etnografia na narrativa latino-americana contemporânea. Rio de Janeiro. 2006. 
KORNBLATT, J. D. The Wisdom Writings of Vladimir Solovyov. Nova York: Cornell University Press, 2009.

KRASICKI, J. Posthumanism and Russian Religious Thought. Studies in East European Thought, v. 54, n. 1/2, p. 125 a 143, 2002.

LEBRUN, G. A aporética da coisa em si. Em: Sobre Kant. Tradução de José Oscar de Almeida Marques, Maria Regina Avelar Coelho da Rocha e Rubens Rodrigues Torres Filho. São Paulo: Iluminuras, 2012.

LEBRUN, G. Sobre Kant. Tradução de José Oscar de Almeida Marques, Maria Regina Avelar Coelho da Rocha e Rubens Rodrigues Torres Filho. São Paulo: Iluminuras, 2012.

LEOPOLDO E SILVA, F. A expressão do drama da liberdade em Sartre. Revista Magma, São Paulo, n. 12, p. 19-30, 2015.

LOWE, D. Gounod's Faust and Bulgakov's the Master and Margarita. Russian Review, v. 55, n. 2, p. 279-286, 1996.

LÖWITH, K. De Hegel a Nietzsche. Tradução de Luiz Fernando Barrére Martin e Flamarion Caldeira Ramos. São Paulo: Editora da UNESP, 2014.

MAZZARI, M. Labirintos da aprendizagem: pacto fáustico, romance de formação e outros temas de literatura comparada. São Paulo: Editora 34, 2010.

MAZZARI, M.; GALLE, H. (Orgs.). Fausto e a América Latina. São Paulo: Humanitas, 2010.

MEERSON, M. A. Put' against Logos: The Critique of Kant and Neo-Kantianism by Russian Religious Philosophers in the Beggining of the Twentieth Century. Studies in East European Thought, v. 47, n. 3/4, p. 225-243, 1995.

MELETINSKI, E. M.. Os arquétipos literários. Tradução de Aurora Fornoni Bernardini, Homero Freitas de Andrade e Arlete Orlando Cavaliere. São Paulo: Ateliê Editorial, 2002.

MENDES, R. Vilém Flusser: Uma história do diabo. Dissertação de mestrado. Escola de comunicação e artes da USP. São Paulo: Dissertação de mestrado, 2000.

MEREZHKOVSKY, D. S. Revolution and Religion. In: ROSENTHAL, B. G.; BOHACHEVSKYCHOMIAK, M. (Orgs.). A Revolution of the Spirit: Crisis of Value in Russia, 1890-1924. New York: Fordham University Press, 1990. p. 189-221.

MISLER, N. Postfazione. In: FLORENSKIJ, P. Lo spazzio e il tempo nell'arte. Milão: Adelphi Edizioni, 2012. p. 367-402.

MORETTI, F. (Org.). A cultura do romance. Tradução de Denise Bottmann. São Paulo: Cosac Naify, 2009.

Nachrichten aus der ideologischen Antike - Marx - Eisenstein - Das Kapital. A. Kluge (Dir.). B. Groys (Entrevistado). Suhrkamp Verlag, 2008. CD.

NATALI, M. P. A política da nostalgia: Um estudo das formas do passado. São Paulo: Nankin, 2006.

NIETZSCHE, F. O anticristo; Maldição ao cristianismo; Ditirambos de Dionísio. Tradução de Paulo César de Souza. São Paulo: Companhia das Letras, 2007. 
NIETZSCHE, F. WERKE, Kritische Gesamtausgabe (30 Volumes). Berlim: Walter de Gruyter \& Co., $1967 / 1978$.

NIVAT, G. Elementos Milenaristas na Revolução Russa. Estudos Avançados, São Paulo, v. 12, n. 32, jan.-abr. 1998. Disponivel em: <http://www.scielo.br/scielo.php?script=sci_arttext \&pid=S0103-40141998000100005> . Acesso em: 18 agosto 2016.

OJA, M. F. Bulgakov's Ironic Parallel between Margarita and Afranius. Slavic Review, v. 50, n. 1, p. 144-149, 1991.

PHILIPSON, G. S. O cômico do Fausto de Goethe em O Mestre e Margarida de Bulgákov. Ipseitas, São Carlos, v. 1, n. 2, p. 117-131, jul./dez. 2015.

PUSHKIN, .A. A filha do capitão. Tradução de Helena S. Nazário. São Paulo: Perspectiva, 1980.

ROSENFELD, A. Letras e leitura. São Paulo: Perspectiva, EDUSP; Campinas: Editora da UNICAMP, 1994.

ROSENSHIELD, G. "The Master and Margarita" and the Poetics of Aporia: A Polemical Article. Slavic Review, v. 56, n. 2, p. 187-211, 1997.

ROSENTHAL, B. G. Nietzsche in Russia. Princeton: Princeton University Press, 1986.

ROSENTHAL, B. G. Introduction. In: ROSENTHAL, B. G.; BOHACHEVSKY-CHOMIAK, M. A Revolution of the Spirit: Crisis of Value in Russia, 1980-1924. Nova Iorque: Fordham University Press, 1990.

ROSENTHAL, B. G. (Org.). Nietzsche and Soviet Culture: Ally and Adversary. Cambridge: Cambridge University Press, 1994.

ROSENTHAL, B. G. (Org.). New Myth, New World: From Nietzsche to Stalinism. University Park, Pennsylvania: The Pennsylvania State University Press, 2002.

ROSENTHAL, B. G.; BOHACHEVSKY-CHOMIAK, M. (Orgs.). A Revolution of the Spirit: Crisis of Value in Russia, 1980-1924. Nova Iorque: Fordham University Press, 1990.

SAFATLE, V. Sobre o riso que não reconcilia: Notas a respeito da "ideologia da ironização". A Parte Rei, n. 55, 2008.

SMOLIN, М. КОДЫ, КЛЮЧИ, СИМВОЛЫ В РОМАНЕ "МАСТЕР И МАРГАРИТА" [Códigos, chaves e símbolos no romance 'O Mestre e Margarida']. Moscou: Vector, 2008.

SOKOLOV, B. Тайны «Мастера и Маргариты»: Расшифрованный Булгаков [Segredos de "O Mestre e Margarida": Bulgákov decifrado]. Moscou: ECSMO, 2006.

SOKOLOV, В. Булгаковская Энциклопедия [Enciclopédia de Bulgákov]. Moscou: ECSMO, 2007. SOLOVIEV, V. S. A Story of Anti-Christ. Lexington: Kassock Bros. Publishing, 2012.

STRADA, V. EuroRussia: Letteratura e cultura da Pietro il Grande alla Rivoluzione. Roma: Editori Laterza, 2005.

STRADA, V. O Mestre e Margarida (Mikhail Bulgákov, 1928-40). In: MORETTI, F. (Org.). A cultura do romance. Tradução de Denise Bottmann. São Paulo: Cosac Naify, 2009. p. 1007-1012. 
SZONDI, P. Teoria do drama moderno (1880-1950). Tradução de Luiz Sérgio Repa. São Paulo: Cosac Naify, 2011.

TODOROV, T. Prefácio à edição francesa. In: BAKHTIN, M. Estética da criação verbal. Tradução de Paulo Bezerra. São Paulo: Editora WMF Martins Fontes, 2015.

TROTSKY, L. Literatura e revolução. tradução de Luiz Alberto Moniz. Bandeira. Rio de Janeiro: Jorge Zahar Ed., 2007.

TURGUÊNIEV, I. Pais e filhos. Tradução de Rubens Figueiredo. São Paulo: Cosac Naify, 2006.

TYNJANOV, J. Avanguardia e tradizione. Tradução de Sergio Leone. Bari: Dedalo libri, 1968.

WEEKS, L. D. (Org.). The Master \& Margarida: A critical Companion. Evanston: Northwestern University Press, 1996.

WEIR, J. The Autor as a Hero: Self and Tradition in Bulgakov's Master and Margarita, Pasternak's Dr. Zhivago, and Nabokov's The Gift. Evanston: Northwestern University Press, 2002. 